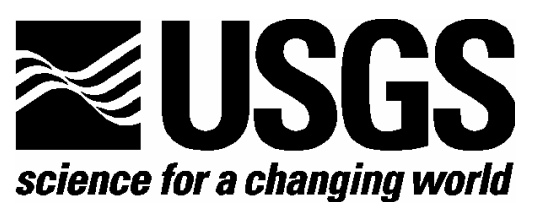

\title{
Chemical Analyses of Ground and Surface Waters, Ester Dome, Central Alaska, 2000- 2001
}

This report is preliminary and has not been reviewed for conformity with U.S. Geological Survey editorial standards or with the North American Stratigraphic Code

\section{Open-File Report 03-244}

\section{U.S. Department of the Interior U.S. Geological Survey}




\section{Chemical Analyses of Ground and Surface Waters, Ester Dome, Central Alaska, 2000-2001}

by P.L. Verplanck ${ }^{1}$, S.H. Mueller ${ }^{2}$, E.K. Youcha ${ }^{3}$, R.J. Goldfarb ${ }^{2}$, R.F. Sanzolone ${ }^{2}$, R.B. McCleskey $^{1}$, P.H. Briggs ${ }^{2}$, M. Roller ${ }^{4}$, M. Adams ${ }^{2}$, and D.K. Nordstrom ${ }^{1}$

${ }^{1}$ U.S. Geological Survey, Boulder, CO 80303

${ }^{2}$ U.S. Geological Survey, Denver, CO 80225

${ }^{3}$ University of Alaska, Fairbanks, Fairbanks, AK 99775

${ }^{4}$ Fairbanks Gold Mining Incorporated, Fairbanks, AK 99707

\section{U.S. GEOLOGICAL SURVEY}

Open-File Report 03-244

Boulder, Colorado 


\section{U.S. DEPARTMENT OF THE INTERIOR}

GALE NORTON, Secretary

\section{U.S. GEOLOGICAL SURVEY}

Charles G. Groat, Director

The use of trade, product, or firm names in this report is for descriptive purposes only and does not constitute endorsement by the U.S. Government.

For additional information write to:

Chief, Branch of Regional Research

U.S. Geological Survey

Denver Federal Center

Box 25046, MS 418

Denver, Colorado 80225 
Abstract ............................................................. 1

Introduction....................................................... 1

Purpose and Scope.......................................... 2

Acknowledgements.......................................... 2

Description of Study Area......................................... 5

Regional and Local Geology.................................. 5

Methods of Study ................................................... 6

Water-Chemistry Sampling.................................. 6

Water-Chemistry Analyses.................................. 7

Quality Assurance................................................. 9

Chemical Data...................................................... 11

References Cited................................................... 39

\section{FIGURES}

1. Map of Alaska with location of study area ........................ 2

2. Topographic map of Ester Dome, Alaska with sampling site locations............................................................ 3

3. Comparison of analytical results by ICP-AES and ICP-MS for Ba, Mn, and Sr. ........................................ 12

\section{TABLES}

1. Sampling site locations......................................... 4

2. Methods of analysis and detection limits....................... 8

3. Dissolved organic carbon determinations ....................... 9

4. ${ }^{34} \mathrm{~S}$ and ${ }^{18} \mathrm{O}$ isotope determinations............................ 10

5. Results of water analyses of Ester Dome, Alaska.................. 13

6. Water-quality data for field blanks, Ester Dome, Alaska.............. 38 


\title{
Chemical Analyses of Ground and Surface Waters, Ester Dome, Central Alaska, 2000-2001
}

\author{
by P.L. Verplanck, S.H. Mueller, E. Youcha, R.J. Goldfarb, R.F. Sanzolone, \\ R.B. McCleskey, P.H. Briggs, M. Roller, M. Adams, and D.K. Nordstrom
}

\begin{abstract}
Water analyses are reported for ground and surface waters collected at 33 sites on and near Ester Dome, Fairbanks area, central Alaska during 2000-2001. This interdisciplinary study focused on documenting the temporal and spatial chemical variations in arsenic concentrations to elucidate the processes that lead to elevated arsenic concentrations in ground water. Field parameters and water analyses are reported for 17 domestic wells, 13 monitoring well sites, and 3 surface water sites. Sampling occurred during November 2000, February 2001, May 2001, July 2001, and September 2001. Waters in the study area are primarily $\mathrm{Ca}-\mathrm{HCO}_{3}$ type, with $\mathrm{pH}$ values ranging from 5.97 to 7.87. Dissolved arsenic concentrations ranged from less than 3 to 1160 micrograms per liter.
\end{abstract}

\section{INTRODUCTION}

Ester Dome, located along the western margin of the city of Fairbanks, Alaska (fig. 1), is known to contain ground waters with high dissolved arsenic concentrations. For example, in the early 1970's arsenic concentrations in excess of 1 milligram per liter $(\mathrm{mg} / \mathrm{L})$ were reported (Harrington and others, 1978). These initial findings led to investigations by researchers from the University of Alaska, Fairbanks and the U. S. Geological Survey on the distribution of arsenic in ground water in the Fairbanks area (for example Johnson and others, 1978; Hawkins and others, 1982; McCrum, 1985). In addition, the Center for Disease Control undertook an epidemiological evaluation of 147 people in the Ester Dome area to investigate the potential health effects related to elevated arsenic concentrations in domestic wells (Harrington and others, 1978).

Process-related studies by U. S. Geological Survey scientists are underway to further delineate the distribution of arsenic in ground water in the Fairbanks area and to assess the factors controlling variations in dissolved arsenic concentrations (Farmer and others, 1998; Mueller and others, 2001; Verplanck and others, 2001; Mueller, 2002). An understanding of arsenic distribution and mobility is important for land use decision-making. The initial phase of this work was a reconnaissance of the Fairbanks area, and this study is a more detailed investigation of an area of major concern within that study area, with the analytical results reported here. Spatial and temporal variability of major, minor, and trace constituents in ground and surface waters in the Ester Dome were determined by sampling both domestic and monitoring wells. Homes on Ester Dome area have individual wells with depths of approximately 25 to $120 \mathrm{~m}$. In addition, monitoring wells have been drilled within and adjacent to Ryan Lode, a gold-bearing quartz vein deposit with excavations along mineralized fractures.

This was a collaboration between the U. S. Geological Survey and Water and Environmental Research Center at the University of Alaska Fairbanks that includes a Master 


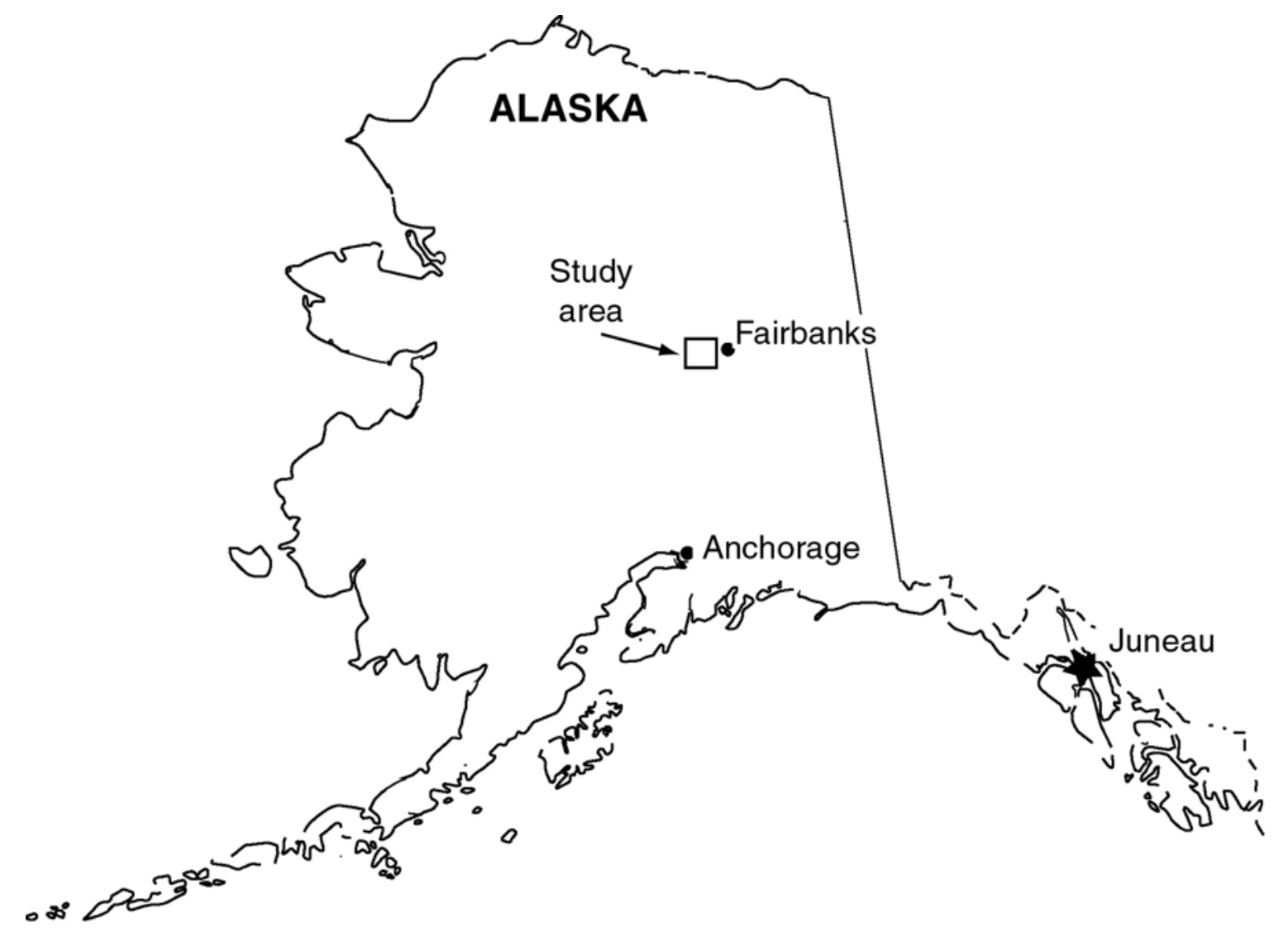

Figure 1. Map of Alaska with location of study area.

of Science thesis to evaluate the ground-water flow system of Ester Dome (Youcha, 2003). Ground-water levels were monitored at fifty sites (including all well sites sampled during this study) on Ester Dome for two years to evaluate temporal and spatial fluctuations. A ground-water flow model was developed to aid in the understanding of these geohydrologic processes.

\section{Purpose and Scope}

The purpose of this report is to present water-chemistry data including field parameters, major, minor, and trace constituents for water samples collected between November, 2000 and October, 2001 on and near Ester Dome, Alaska (table 1, fig. 2). Analytical results are reported for 139 water samples from 33 sites. Quality-assurance data associated with these water-chemistry data are presented.

\section{Acknowledgements}

This cooperative study included personnel from the U. S. Geological Survey, University of Alaska at Fairbanks, Fairbanks Gold Mining Inc., and the University of Colorado at Boulder. In addition, homeowners on Ester Dome allowed us to sample their wells. Manuscript review by Bronwen Wang was appreciated. 


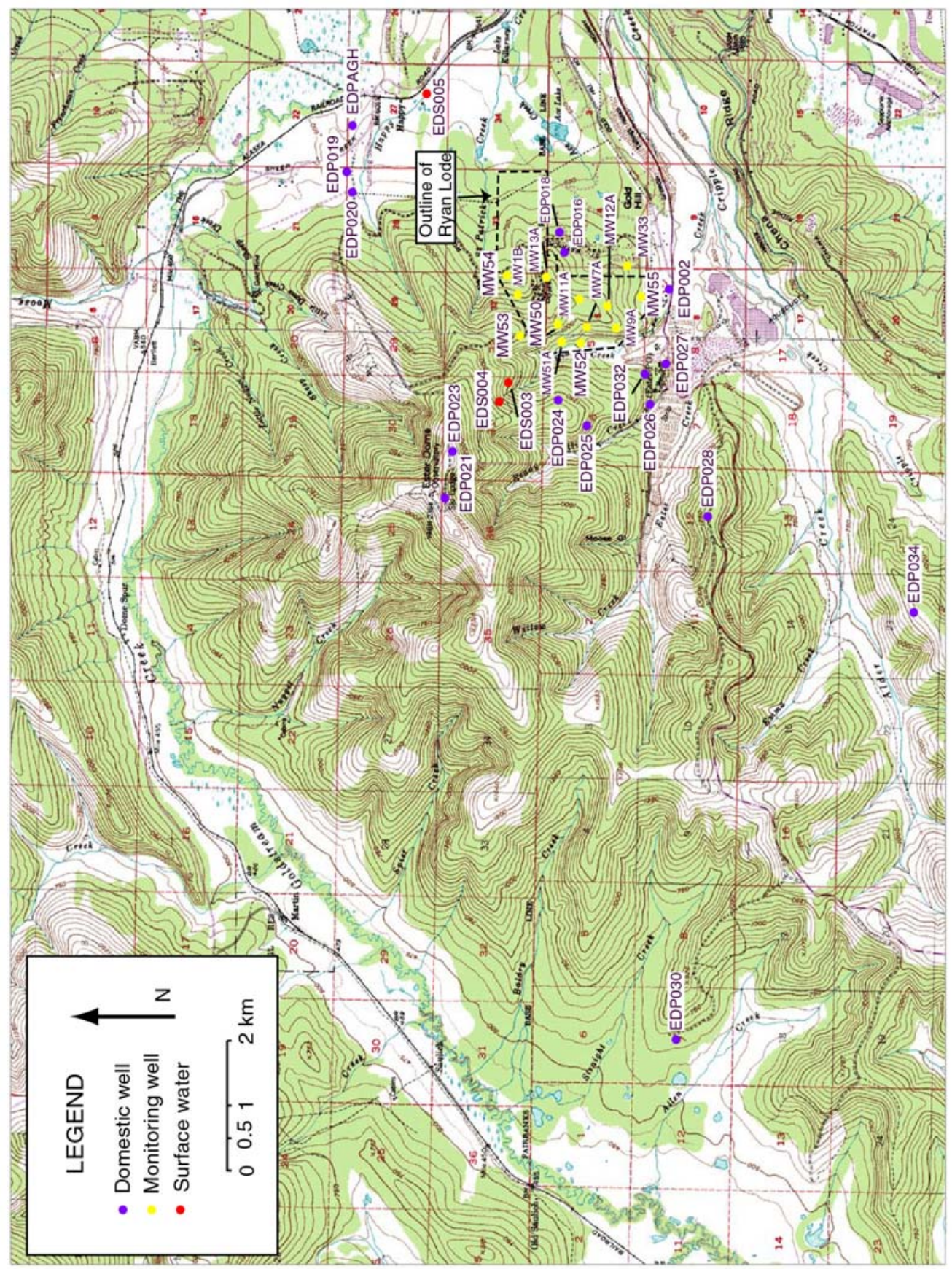

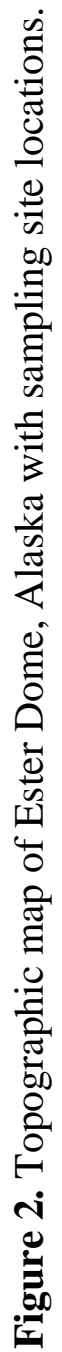


Table 1. Sampling site locations

[m, meters; Hwy, highway]

\begin{tabular}{|c|c|c|c|c|}
\hline SAMPLE NUMBER & LATITUDE & LONGITUDE & LOCATION & ELEVATION (m) \\
\hline \multicolumn{5}{|l|}{ Domestic Wells } \\
\hline EDP002 & 64.84707 & -147.98485 & Townsend Way & 188 \\
\hline EDP016 & 64.86084 & -147.97017 & Dome Road & 264 \\
\hline EDP018 & 64.86161 & -147.96362 & Duece Road & 238 \\
\hline EDP019 & 64.89259 & -147.94487 & Ester Dome Road & 206 \\
\hline EDP020 & 64.89173 & -147.95151 & Ester Dome Road & 213 \\
\hline EDP021 & 64.87758 & -148.05156 & Styx River Road & 662 \\
\hline EDP023 & 64.87659 & -148.03615 & Ullrbahn Road & 637 \\
\hline EDP024 & 64.86142 & -148.01878 & Stone Road & 386 \\
\hline EDP025 & 64.85720 & -148.02699 & Azurite Road & 342 \\
\hline EDP026 & 64.84808 & -148.01964 & Truette Lane & 215 \\
\hline EDP027 & 64.84588 & -148.00633 & Parks Hwy/Old Nenana Hwy & 182 \\
\hline EDP028 & 64.83941 & -148.05612 & Old Wood Road & 406 \\
\hline EDP030 & 64.84272 & -148.22791 & Old Ridge Trail & 185 \\
\hline EDP032 & 64.84886 & -148.00974 & Upper Ester Loop & 226 \\
\hline EDP033 & 64.87768 & -148.05430 & Beggars Roost Run & 640 \\
\hline EDP034 & 64.80923 & -148.08634 & Peartree Lane & 417 \\
\hline EDPAGH & 64.89144 & -147.93083 & Sheep Creek Road & 184 \\
\hline \multicolumn{5}{|l|}{ Monitoring Wells } \\
\hline MW1B & 64.86751 & -147.98432 & Ryan Lode & 279 \\
\hline MW7A & 64.85745 & -147.99456 & Ryan Lode & 303 \\
\hline MW9A & 64.85316 & -147.99476 & Ryan Lode & 284 \\
\hline MW11A & 64.85859 & -147.98551 & Ryan Lode & 303 \\
\hline MW12A & 64.85450 & -147.98761 & Ryan Lode & 283 \\
\hline MW13A & 64.86344 & -147.97843 & Ryan Lode & 341 \\
\hline MW33 ${ }^{1}$ & 64.85168 & -147.97427 & -- & 236 \\
\hline MW50 & 64.86165 & -147.99379 & Ryan Lode & 338 \\
\hline MW51A & 64.86104 & -147.99953 & Ryan Lode & 284 \\
\hline MW52 & 64.85830 & -147.99990 & Ryan Lode & 263 \\
\hline MW53 ${ }^{1}$ & 64.86714 & -147.99776 & Ester Drive & 394 \\
\hline MW54 & 64.86930 & -147.97748 & Ryan Lode & 250 \\
\hline MW55 & 64.84959 & -147.98434 & Ryan Lode & 216 \\
\hline \multicolumn{5}{|l|}{ Surface Water } \\
\hline$\overline{\text { EDS003 }}$ & 64.86993 & -148.01894 & Eva Creek-Trench & 380 \\
\hline EDS004 & 64.86844 & -148.01354 & Eva Creek-Seep & 390 \\
\hline EDS005 & 64.88249 & -147.92324 & Happy Creek-Wetland & 180 \\
\hline
\end{tabular}

${ }^{1}$ Domestic well used as a monitoring well 


\section{DESCRIPTION OF STUDY AREA}

Ester Dome covers approximately $260 \mathrm{~km}^{2}$, ranges in elevation from 180 to $720 \mathrm{~m}$, and lies within the sub-arctic of interior Alaska. The climate of interior Alaska consists of large temperature variations, and is typified by long winters and short summers. For the period 1904-2002, the average annual high temperature at Fairbanks was $2.72^{\circ} \mathrm{C}$ and low temperature was $-8.72^{\circ} \mathrm{C}$ (National Weather Service, 2002). Fairbanks has an arid climate with an average winter snowfall of $179.8 \mathrm{~cm}$, with an average annual-water content of 9.83 cm (National Weather Service, 2002). The average summer precipitation is $17.65 \mathrm{~cm}$ (National Weather Service, 2002). Precipitation varies with elevation such that the highest elevations in the uplands receive more precipitation than the valley bottoms.

Permafrost, defined as rock or soil with a temperature below $0^{\circ} \mathrm{C}$ for two or more years, and seasonally frozen ground play an important role in the ground-water dynamics. Valley bottoms and north-facing slopes of many hills surrounding Fairbanks are underlain by discontinuous permafrost. Confined or artesian conditions may exist in valley-bottom aquifers overlain by ice-rich silt. Additionally, ice-rich permafrost can block vertical recharge from entering the aquifer. Permafrost thickness may be as much as $30 \mathrm{~m}$ (Pewe, 1958). In seasonally frozen Fairbanks Silt the vertical hydraulic conductivity of ice-rich silt is two orders of magnitude lower than unfrozen and dry frozen silt (Kane and Stein, 1983).

\section{Regional and Local Geology}

The bedrock in the Fairbanks area is part of the Yukon-Tanana terrane (YTT), a displaced pericratonic block of late Paleozoic and older rocks that has been polydeformed and polymetamorphosed (Foster and others, 1994). The YTT is bounded by two major Cenozoic right-lateral strike slip faults, the Tintina fault to the northeast and the Denali fault to the southwest (Foster, 1994). The Fairbanks area has been deformed by multiple, northwest-trending, isoclinal folds, and later by northeast-trending folds. East-to northeastoriented faults and shears are common, and these faults and shears are often mineralized with gold-bearing quartz veins, and contain extensive sericitic gouge (LeLachuer, 1991; McCoy and others, 1997).

The geology of the Fairbanks area, as described by Robinson (1982), Foster and others (1994), and Newberry and Bundtzen (1996), consists of the following rock types from oldest to youngest: 1) amphibolite facies metasedimetary and metavolcanic rocks of the Proterozic (?) to Paleozoic Fairbanks Schist, a heterogeneous unit comprised of quartzite and muscovite-quartz \pm garnet \pm biotite \pm chlorite schist (Foster and others, 1994), 2) Ordovician to Upper Devonian low-grade metarhyolites, amphibolites, phyllites, and metasiliclastic rocks of the Birch Hill sequence, 3) amphibolite facies metavolcanic and metasedimentary rocks of the Muskox sequence, and 4) ca. 90 Ma granites and granodiorites that underlie Ester Dome, and other domes in the region, which are often spatially and temporally related to gold mineralization (McCoy and others., 1997). Minor lithologies also include amphibolite, magnetite-rich biotite schist, marble, eclogite facies schist, amphibolite, and quartzite of the Devonian to Mississippian Chatinika Group, Devonian orthogniess, and Tertiary basalt (Newberry and Bundtzen, 1996). Loess of late Cenozoic age, has been remobilized into thick alluvial deposits frequently overlain with silt in the valley bottoms (Pewe, 1975; Newberry and Bundtzen, 1996). The thickness of the loess ranges between a few centimeters on ridges and hill tops to as much as $35 \mathrm{~m}$ in creek 
valleys, where the loess can contain organic-rich layers and peat lenses as thick as $3 \mathrm{~m}$ (Pewe, 1958; Preece and others, 1999.) Coarse river gravels, interbedded with finer fan gravels, overly the bedrock beneath the loess valley areas. Some of the coarse gravel has been mined for placer gold.

Auriferous vein deposits formed contemporaneously with the $90 \mathrm{Ma}$ intrusions and are hosted either by the granitic rocks themselves (Ft. Knox) or along contacts between the granites and schist (Ryan Lode on Ester Dome), or strictly within the schist (Hi-Yu lode mine; Metz, 1991). Where hosted by granitic rocks, the veins are typically very low in sulfide minerals (less than 1 volume percent), but often show enrichment in bismuthtellurium-tungsten (McCoy and others, 1997). However, within veins hosted in the schist, the sulfide mineral abundances are higher, typically with 2-3 volume percent arsenopyrite, stibnite, and pyrite (Newberry and Bundtzen, 1996; McCoy and others, 1997). Vein alteration minerals include albite, sericite (white mica), \pm ankerite \pm carbonaceous material. The sulfide minerals are also commonly formed in these altered rocks. More distal, wallrock alteration is characterized by chloritized biotite and hornblende (McCoy and others, 1997). Scorodite is often present as a weathering phase of arsenopyrite, mainly found as vein coatings, fracture fills, and breccia cement (Metz, 1991; LeLacheur, 1991).

\section{METHODS OF STUDY}

\section{Water-Chemistry Sampling}

Water-chemistry samples were collected seasonally from water wells during 2000 and 2001, and a few surface water samples were collected during July, 2001. Sampling sites were selected to provide spatial coverage of the study area (fig. 2). No sites were located on the north side of Ester Dome because of the paucity of wells. Five sampling trips

(November, 2000, February, 2001, May, 2001, July, 2001, and September, 2001) were made to evaluate temporal variations. Two types of wells, monitoring and domestic wells, were sampled. The monitoring wells are located on or adjacent to Ryan Lode, a lode gold deposit that has been mined, both underground and with open cuts, sporadically since 1912 with the greatest production occurring between 1985 and 1989. Before sampling, monitoring wells were purged of three well volumes, and $\mathrm{pH}$, specific conductance and temperature were monitored after each well volume. The static water level was measured before and after pumping. Domestic wells were sampled using a PVC hose connected to the pressure tank intake. Initially, water was allowed to discharge until the pump turned on. As the water continued to discharge, specific conductance and water temperature were monitored until they were stable, usually at a water temperature between 3 and $4^{\circ} \mathrm{C}$. Two monitoring wells (MW33 and MW 53) are domestic wells for homes adjacent to the Ryan Lode deposit, and the domestic well sampling procedure was followed at these sites.

On-site measurements of $\mathrm{pH}$, specific conductance, and temperature were obtained. At each site the $\mathrm{pH}$ electrode was calibrated using two buffers that bracketed the measured $\mathrm{pH}$ and were thermally equilibrated with the water sample. At selected sites, dissolved oxygen concentration and Eh were measured. Water-chemistry samples consisted of an unfiltered, unacidified sample for oxygen isotopic compositions, an unfiltered, acidified sample preserved with nitric acid for total recoverable cations, two filtered, unacidified samples for 1) anion determinations and alkalinity, and 2) sulfur isotopic determinations, a filtered, acidified sample preserved with nitric acid for dissolved cation determinations, and two 
filtered samples, acidified with hydrochloric acid, for arsenic and iron redox determinations. Samples were filtered on site using $0.45 \mu \mathrm{m}$ pore size capsule filters. In addition, during the July sampling, at selected sites, an additional cation sample was collected and filtered using a tangential-flow filtration apparatus, which was equipped with a 10,000 daltons filter membrane, equivalent to $\sim 0.005 \mu \mathrm{m}$ pore size (Alpers and others, 2000). The purpose of these samples was to determine if the routine filtration with $0.45 \mu \mathrm{m}$ filter membrane size adequately removed colloidal material in these samples.

\section{Water-Chemistry Analyses}

All reagents were of a purity at least equal to the reagent-grade standards of the American Chemical Society. Double-distilled de-ionized water, and re-distilled acids using a sub-boiling purification technique (Kuehner and others, 1972), were used in all preparations. The methods used and the detection limit for each analysis are summarized in table 2. For inductively-coupled plasma atomic-emission spectroscopy (ICP-AES) and inductively-coupled plasma mass spectrometry (ICP-MS), USGS standard reference water samples and blanks were included with each sample suite. Major cations (calcium, magnesium, potassium, and sodium) and silica for total recoverable and dissolved samples were determined using a Perkin Elmer Optima 3000 ${ }^{\mathrm{TM}}$ ICP-AES (Briggs, 2002).

Minor and trace elements (aluminum, arsenic, barium, beryllium, bismuth, boron, cadmium, cesium, chromium, cobalt, copper, lead, lithium, manganese, molybdenum, nickel, rare earth elements, rhenium, selenium, strontium, tellurium, thorium, uranium, vanadium, yttrium, and zinc) for total recoverable and dissolved samples were analyzed with the ICP-MS using a method developed by the U.S. Geological Survey (Meier and others, 1994; Lamothe and others, 2002). This method is used to directly determine the elements in the water samples without need for any pre-concentration or dilution. Elemental detection limits are in the sub-parts per billion range (table 2), and the working linear range is six or more orders of magnitude.

Concentrations of major anions (chloride, fluoride, nitrate, and sulfate) were determined by ion chromatography (Brinton and others, 1995) using a Dionex 2010i ${ }^{\mathrm{TM}}$ ion chromatograph with $10-\mu \mathrm{L}$ and $50-\mu \mathrm{L}$ sample loops. Standards were prepared from compounds of the highest commercially available purity. U.S. Geological Survey standard reference water samples were used as independent quality control standards. Alkalinity (as $\mathrm{HCO}_{3}{ }^{-}$) was determined using an Orion $960^{\mathrm{TM}}$ autotitrator and standardized $\mathrm{H}_{2} \mathrm{SO}_{4}$ (Barringer and Johnsson, 1989). Samples were diluted as necessary to bring the analyte concentration within the optimal range of the method. Dissolved organic carbon (DOC) concentrations (Table 3) were determined by the wet persulfate oxidation method (Aiken, 1992).

Iron (II) redox species and total iron, in filtered, $\mathrm{HCl}$ acidified samples, were determined using a modification of the FerroZine ${ }^{\mathrm{TM}}$ colorimetric method (Stookey, 1970; To and others, 1999) with a Hewlett Packard 8453' spectrophotometer. After filtration and preservation, samples for As (III) species determination were kept refrigerated and in the dark prior to analysis. Arsenic III species were determined by ICP-MS after ion exchange separation of the inorganic As III species using SAX (Strong Ion Exchange Resin) and elution with malonate/acetate buffer solution at $\mathrm{pH} 4.7$. 
Table 2. Methods of analysis and detection limits

[mg/L, milligram per liter; $\mu \mathrm{g} / \mathrm{L}$, microgram per liter; IC, ion chromatography; ICP-MS, inductively coupled plasma-mass spectrometry; ICP-AES, inductively coupled plasma-atomic emission spectroscopy]

\begin{tabular}{|c|c|c|c|c|c|}
\hline Element & Detection limit & Method & Element & Detection limit & Method \\
\hline $\mathrm{Ag}$ & $3 \mu \mathrm{g} / \mathrm{L}$ & ICP-MS & $\mathrm{Mn}$ & $0.02 \mu \mathrm{g} / \mathrm{L}$ & ICP-MS \\
\hline Al & $10 \mu \mathrm{g} / \mathrm{L}$ & ICP-AES & Mo & $2 \mu \mathrm{g} / \mathrm{L}$ & ICP-MS \\
\hline $\mathrm{Al}$ & $2 \mu \mathrm{g} / \mathrm{L}$ & ICP-MS & $\mathrm{Na}$ & $0.1 \mathrm{mg} / \mathrm{L}$ & ICP-AES \\
\hline$A s^{1}$ & $3,1 \mu \mathrm{g} / \mathrm{L}$ & ICP-MS & $\mathrm{Nb}$ & $0.2 \mu \mathrm{g} / \mathrm{L}$ & ICP-MS \\
\hline$A s^{1}(I I I)$ & $5,3,0.3 \mu \mathrm{g} / \mathrm{L}$ & ICP-MS & $\mathrm{Nd}$ & $0.01 \mu \mathrm{g} / \mathrm{L}$ & ICP-MS \\
\hline $\mathrm{Ba}$ & $1 \mu \mathrm{g} / \mathrm{L}$ & ICP-AES & $\mathrm{Ni}$ & $0.4 \mu \mathrm{g} / \mathrm{L}$ & ICP-MS \\
\hline $\mathrm{Ba}$ & $0.2 \mu \mathrm{g} / \mathrm{L}$ & ICP-MS & $\mathrm{NO}_{3}$ & $0.05 \mathrm{mg} / \mathrm{l}$ & IC \\
\hline $\mathrm{Be}$ & $0.05 \mu \mathrm{g} / \mathrm{L}$ & ICP-MS & $P$ & $10 \mu \mathrm{g} / \mathrm{L}$ & ICP-MS \\
\hline $\mathrm{Bi}$ & $0.2 \mu \mathrm{g} / \mathrm{L}$ & ICP-MS & $\mathrm{Pb}$ & $0.05 \mu \mathrm{g} / \mathrm{L}$ & ICP-MS \\
\hline $\mathrm{Ca}$ & $1 \mathrm{mg} / \mathrm{L}$ & ICP-AES & $\mathrm{Pr}$ & $0.01 \mu \mathrm{g} / \mathrm{L}$ & ICP-MS \\
\hline $\mathrm{Cd}$ & $0.02 \mu \mathrm{g} / \mathrm{L}$ & ICP-MS & $\mathrm{Rb}$ & $0.01 \mu \mathrm{g} / \mathrm{L}$ & ICP-MS \\
\hline $\mathrm{Ce}$ & $0.01 \mu \mathrm{g} / \mathrm{L}$ & ICP-MS & $\mathrm{Sb}$ & $0.3 \mu \mathrm{g} / \mathrm{L}$ & ICP-MS \\
\hline $\mathrm{Cl}$ & $0.01 \mathrm{mg} / \mathrm{l}$ & IC & $\mathrm{Sc}$ & $0.6 \mu \mathrm{g} / \mathrm{L}$ & ICP-MS \\
\hline Co & $0.02 \mu \mathrm{g} / \mathrm{L}$ & ICP-MS & $\mathrm{Se}$ & $1 \mu \mathrm{g} / \mathrm{L}$ & ICP-MS \\
\hline $\mathrm{Cr}$ & $1 \mu \mathrm{g} / \mathrm{L}$ & ICP-MS & $\mathrm{SiO}_{2}$ & $0.4 \mathrm{mg} / \mathrm{L}$ & ICP-AES \\
\hline Cs & $0.02 \mu \mathrm{g} / \mathrm{L}$ & ICP-MS & $\mathrm{SO}_{4}$ & $0.05 \mathrm{mg} / \mathrm{l}$ & IC \\
\hline $\mathrm{Cu}$ & $0.5 \mu \mathrm{g} / \mathrm{L}$ & ICP-MS & $\mathrm{Sm}$ & $0.01 \mu \mathrm{g} / \mathrm{L}$ & ICP-MS \\
\hline Dy & $0.005 \mu \mathrm{g} / \mathrm{L}$ & ICP-MS & $\mathrm{Sr}$ & $1 \mu \mathrm{g} / \mathrm{L}$ & ICP-AES \\
\hline $\mathrm{Er}$ & $0.005 \mu \mathrm{g} / \mathrm{L}$ & ICP-MS & $\mathrm{Sr}$ & $0.5 \mu \mathrm{g} / \mathrm{L}$ & ICP-MS \\
\hline $\mathrm{Eu}$ & $0.005 \mu \mathrm{g} / \mathrm{L}$ & ICP-MS & $\mathrm{Ta}$ & $0.02 \mu \mathrm{g} / \mathrm{L}$ & ICP-MS \\
\hline $\mathrm{F}$ & 0.05 mg/l & IC & $\mathrm{Tb}$ & $0.005 \mu \mathrm{g} / \mathrm{L}$ & ICP-MS \\
\hline $\mathrm{Fe}$ & $20 \mu \mathrm{g} / \mathrm{L}$ & ICP-AES & $\mathrm{Te}$ & $0.1 \mu \mathrm{g} / \mathrm{L}$ & ICP-MS \\
\hline $\mathrm{Fe}$ & $2 \mu \mathrm{g} / \mathrm{L}$ & FerroZine & Th & $0.2 \mu \mathrm{g} / \mathrm{L}$ & ICP-MS \\
\hline Fe (II) & $2 \mu \mathrm{g} / \mathrm{L}$ & FerroZine & $\mathrm{Ti}$ & $0.5 \mu \mathrm{g} / \mathrm{L}$ & ICP-MS \\
\hline $\mathrm{Ga}$ & $0.05 \mathrm{vg} / \mathrm{L}$ & ICP-MS & $\mathrm{TI}$ & $0.15 \mu \mathrm{g} / \mathrm{L}$ & ICP-MS \\
\hline $\mathrm{Gd}$ & $0.005 \mu \mathrm{g} / \mathrm{L}$ & ICP-MS & $\mathrm{Tm}$ & $0.005 \mu \mathrm{g} / \mathrm{L}$ & ICP-MS \\
\hline $\mathrm{Ge}$ & $0.02 \mu \mathrm{g} / \mathrm{L}$ & ICP-MS & $U$ & $0.1 \mu \mathrm{g} / \mathrm{L}$ & ICP-MS \\
\hline $\mathrm{Ho}$ & $0.005 \mu \mathrm{g} / \mathrm{L}$ & ICP-MS & V & $0.5 \mu \mathrm{g} / \mathrm{L}$ & ICP-MS \\
\hline $\mathrm{K}$ & $30 \mu \mathrm{g} / \mathrm{L}$ & ICP-MS & W & $0.5 \mu \mathrm{g} / \mathrm{L}$ & ICP-MS \\
\hline La & $0.01 \mu \mathrm{g} / \mathrm{L}$ & ICP-MS & Y & $0.01 \mu \mathrm{g} / \mathrm{L}$ & ICP-MS \\
\hline $\mathrm{Li}$ & $0.1 \mu \mathrm{g} / \mathrm{L}$ & ICP-MS & $\mathrm{Yb}$ & $0.005 \mu \mathrm{g} / \mathrm{L}$ & ICP-MS \\
\hline $\mathrm{Lu}$ & $0.1 \mu \mathrm{g} / \mathrm{L}$ & ICP-MS & $\mathrm{Zn}$ & $0.5 \mu \mathrm{g} / \mathrm{L}$ & ICP-MS \\
\hline $\mathrm{Mg}$ & $0.1 \mathrm{mg} / \mathrm{L}$ & ICP-AES & $\mathrm{Zr}$ & $0.2 \mu \mathrm{g} / \mathrm{L}$ & ICP-MS \\
\hline $\mathrm{Mn}$ & $10 \mu \mathrm{g} / \mathrm{L}$ & ICP-AES & & & \\
\hline
\end{tabular}

${ }^{1}$ Detection limit changed during course of study 
Table 3. Dissolved organic carbon determination for selected sites, Ester Dome, Alaska

[DOC, dissolved organic carbon; mg/L, milligrams per liter]

\begin{tabular}{ccc}
\hline Site & Date & DOC (mg/L) \\
\hline MW01B & $07 / 09 / 01$ & 2.6 \\
MW07A & $07 / 08 / 01$ & 1.3 \\
MW09A & $07 / 10 / 01$ & 1.1 \\
MW11A & $07 / 10 / 01$ & 2.2 \\
MW12A & $07 / 10 / 01$ & 2.1 \\
MW13A & $07 / 09 / 01$ & 1.1 \\
MW33 & $07 / 09 / 01$ & 2.9 \\
MW51 & $07 / 09 / 01$ & 1.1 \\
MW52 & $07 / 08 / 01$ & 1.5 \\
MW54 & $07 / 08 / 01$ & 6.1 \\
MW55 & $07 / 08 / 01$ & 2.6 \\
EDS03 & $07 / 11 / 01$ & 2.7 \\
EDS04 & $07 / 11 / 01$ & 1.5 \\
EDS05 & $07 / 12 / 01$ & 59 \\
\hline
\end{tabular}

The oxygen and sulfur isotopic compositions of a subset of samples were determined (table 4). For oxygen analyses, one microliter of each sample was pipetted into a glass vial, and then the sample and vial were put into a glove bag and atmospheric oxygen was flushed using $\mathrm{CO}_{2}$. Tops with rubber septa were screwed on to the vials. The samples were allowed to equilibrate with the $\mathrm{CO}_{2}$ gas for 10 hours. Oxygen isotopic compositions were determined using a Micromass Optima, with an on-line equilibration method similar to the off-line method described by Epstein and Mayeda (1953). For the sulfur isotopic analyses, the sulfate ion was removed from the samples using the barium sulfate precipitation method. Sulfur isotopic analyses are done by combustion using continuous flow methods described by Giesemann et al. (1994), with a Carlo Erba NC2500 elemental analyzer coupled to either a Micromass Optima or a Finnigan Delta Plus XL mass spectrometer.

\section{QUALITY ASSURANCE}

Quality-control included replicate samples, field equipment blanks, analyses by alternative methods, and calculation of charge imbalance. Replicate samples are two samples that are considered to be essentially identical in composition and were used to estimate variability in environmental data. These samples were collected immediately following the water-chemistry sample and were pumped from the same collection vessel. Each replicate sample is processed through all the steps of the routine water-chemistry sample using a new filter and clean equipment. Replicate samples were analyzed at the same time and using the same instruments as the other samples collected during the same sampling trip. Analytical results of replicate samples are included in table 5, and follow the corresponding water sampled (labeled as duplicate). Most major, minor, and trace element replicate concentrations are within \pm 10 percent of the corresponding water-chemistry sample. 
Table $4 .{ }^{34} \mathrm{~S}$ and ${ }^{18} \mathrm{O}$ isotope determinations

$\left[{ }^{34} \mathrm{~S}\right.$ in permil relative to Canyon Diablo meteorite;

${ }^{18} \mathrm{O}$ in permil relative to VSMOW; --, not analyzed]

\begin{tabular}{|c|c|c|c|}
\hline SITE & DATE & $\delta^{34} \mathrm{~S}$ & $\delta^{18} 0$ \\
\hline \multirow[t]{6}{*}{ EDP016 } & $11 / 13 / 00$ & -- & -20.0 \\
\hline & 02/01/01 & -- & -20.1 \\
\hline & 05/03/01 & -- & -20.0 \\
\hline & 05/03/01 & -- & -20.0 \\
\hline & 07/16/01 & 7.8 & -- \\
\hline & 09/29/01 & -- & -19.9 \\
\hline EDP018 & 07/13/01 & 3.5 & -18.9 \\
\hline EDP019 & 07/11/01 & 11.3 & -- \\
\hline EDP020 & 07/13/01 & 6.1 & -19.5 \\
\hline \multirow[t]{5}{*}{ EDP021 } & $11 / 13 / 00$ & -- & -19.3 \\
\hline & $02 / 02 / 01$ & -- & -19.1 \\
\hline & 05/03/01 & -- & -19.4 \\
\hline & 09/28/01 & -- & -19.5 \\
\hline & 09/28/01 & -- & -19.5 \\
\hline EDP027 & 07/14/01 & 16.8 & -- \\
\hline \multirow[t]{2}{*}{ EDP028 } & $11 / 15 / 00$ & 8.6 & -- \\
\hline & 07/16/01 & -- & -19.0 \\
\hline EDP034 & 07/14/01 & -8.2 & -- \\
\hline EDPAGH & $07 / 11 / 01$ & 20.3 & -- \\
\hline MW01B & 07/09/01 & 5.8 & -- \\
\hline MW07A & 07/08/01 & -- & -- \\
\hline \multirow[t]{4}{*}{ MW09A } & 01/30/01 & -- & -19.0 \\
\hline & 05/02/01 & -- & -18.9 \\
\hline & $10 / 01 / 01$ & -- & -19.2 \\
\hline & 10/01/01 & -- & -19.1 \\
\hline MW11A & 07/10/01 & 4.4 & -- \\
\hline \multirow[t]{5}{*}{ MW12A } & 01/31/01 & -- & -19.7 \\
\hline & 01/31/01 & -- & -19.6 \\
\hline & 05/02/01 & -- & -19.7 \\
\hline & 07/10/01 & 7.9 & -19.7 \\
\hline & $10 / 01 / 01$ & -- & -19.6 \\
\hline MW13 & 07/09/01 & 8.6 & -- \\
\hline MW33 & 07/09/01 & 4.8 & -- \\
\hline MW50 & 07/09/01 & 4.9 & -- \\
\hline MW51 & 07/08/01 & 6.2 & -- \\
\hline MW52 & 07/08/01 & 4.6 & -- \\
\hline MW53 & 07/10/01 & 20.6 & -- \\
\hline MW55 & 07/08/01 & 4.0 & -19.8 \\
\hline EDS003 & 07/11/01 & 14.8 & -- \\
\hline EDS004 & $07 / 11 / 01$ & 24.0 & -19.7 \\
\hline EDS005 & $07 / 12 / 01$ & -- & -16.8 \\
\hline
\end{tabular}


A field equipment blank is a sample prepared using blank (deionized) water that has passed through all the sampling and processing equipment. This type of sample is used to check for the potential contamination of the water-chemistry samples during collection, processing, handling, and analysis. Analytical results are presented in table 6. Most analytes were below analytical detection limits.

Concentrations of cations were determined by ICP-AES and ICP-MS, and if concentrations of trace elements were at least three times the detection limit, good agreement between ICP-AES and ICP-MS results was observed (fig. 3). Barium, manganese, and strontium were chosen for this comparison because the range in concentrations of these elements was within the working range of both analytical techniques.

Data for all samples with complete analyses were checked using the computer program WATEQ4F (Ball and Nordstrom, 1991) for charge imbalance (C.I.), using the following calculation:

$$
\text { C.I. }(\text { percent })=\frac{100 *(\text { sum cations }- \text { sum anions })}{(\text { sum cations }+ \text { sum anions }) \div 2}
$$

where sum cations is the sum of the cations in milliequivalents per liter and sum anions is the sum of the anions in milliequivalents per liter. Note that the results of this calculation are twice the value typically reported by an analytical laboratory because the denominator of the equation is the average of the cations and anions rather than the sum of the ions.

The percent charge imbalance reflects how well the major anions and cations balance and usually is an independent measure of the accuracy of the analytical techniques. The percent charge imbalance was low $(<10 \%)$ for most samples (table 5). Some dilute waters samples had charge imbalances that were greater because of analytical imprecisions when determining concentrations at or near the detection limits.

\section{CHEMICAL DATA}

Chemical results were compiled and are presented in table 5. These circumneutral, Ca$\mathrm{HCO}_{3}$-dominated waters had a range of filtered As concentrations from less than 3 to 1160 micrograms per liter. One well (EDP021), located at the top of the dome, exhibits the greatest temporal variability in filtered As concentration (44.6 to $387 \mu \mathrm{g} / \mathrm{L}$ ), which correlated inversely to the static water level. Spatially, dissolved As concentrations are also quite variable, with wells located a few hundred meters apart having $<3$ and $390 \mu \mathrm{g} / \mathrm{L}$. Although redox chemistry and elemental ratios suggest that a number of processes likely affect the dissolved As concentrations, proximity to mineralized shear zones appears to be the primary control on As concentrations in the ground water (Verplanck and others, 2001). 
A
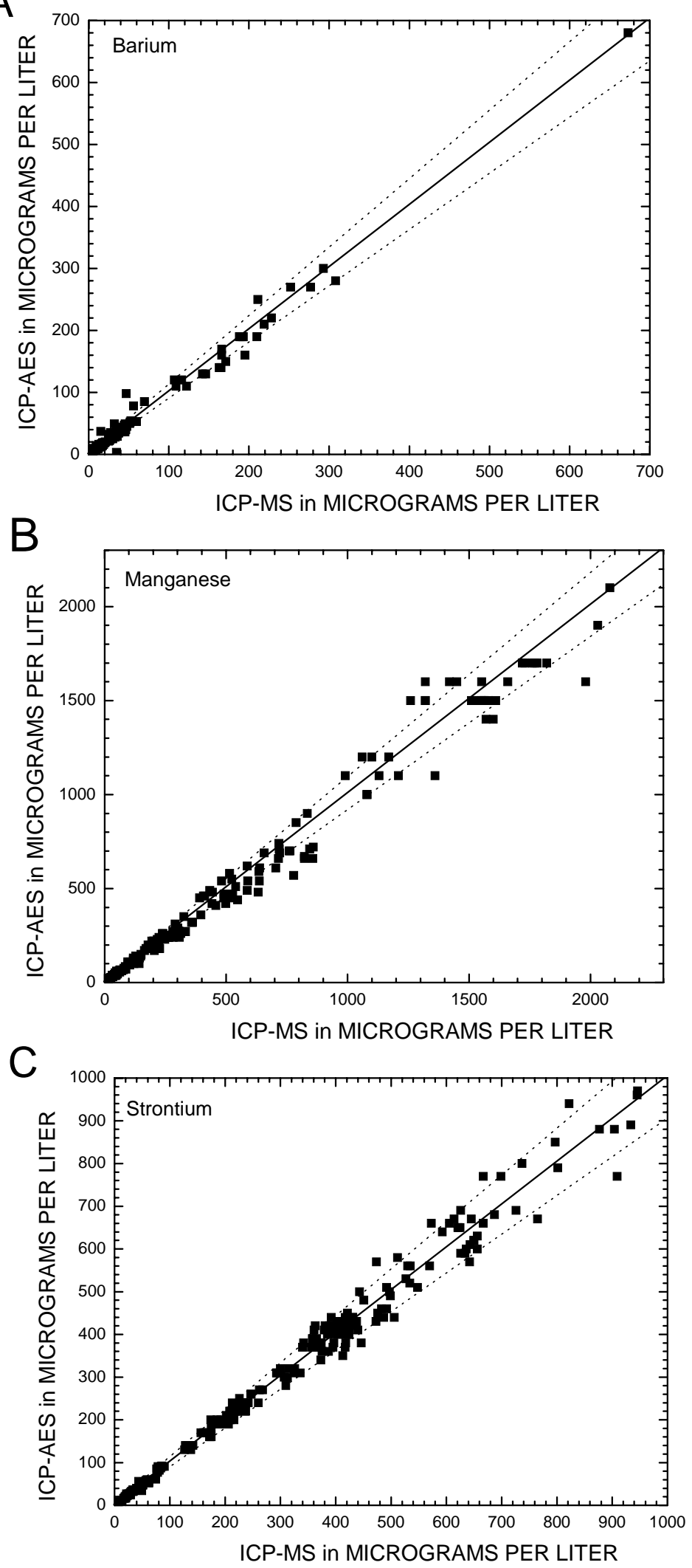

Figure 3. Comparison of analytical results by ICP-AES and ICP-MS for Ba, Mn, and Sr. All samples were filtered and acidified. Diagonal line is 1:1 correspondence; dashed lines are \pm 10 percent. 


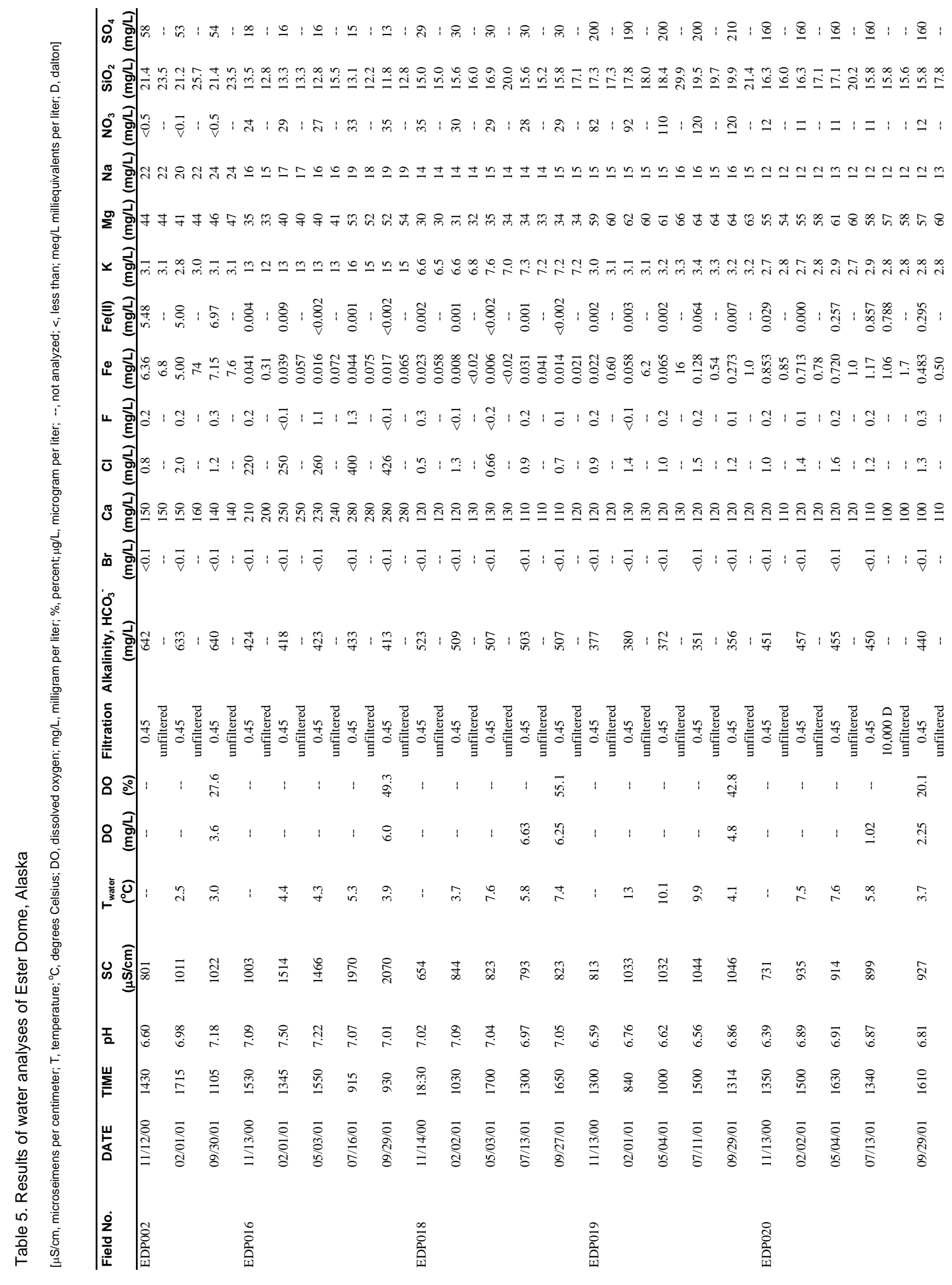




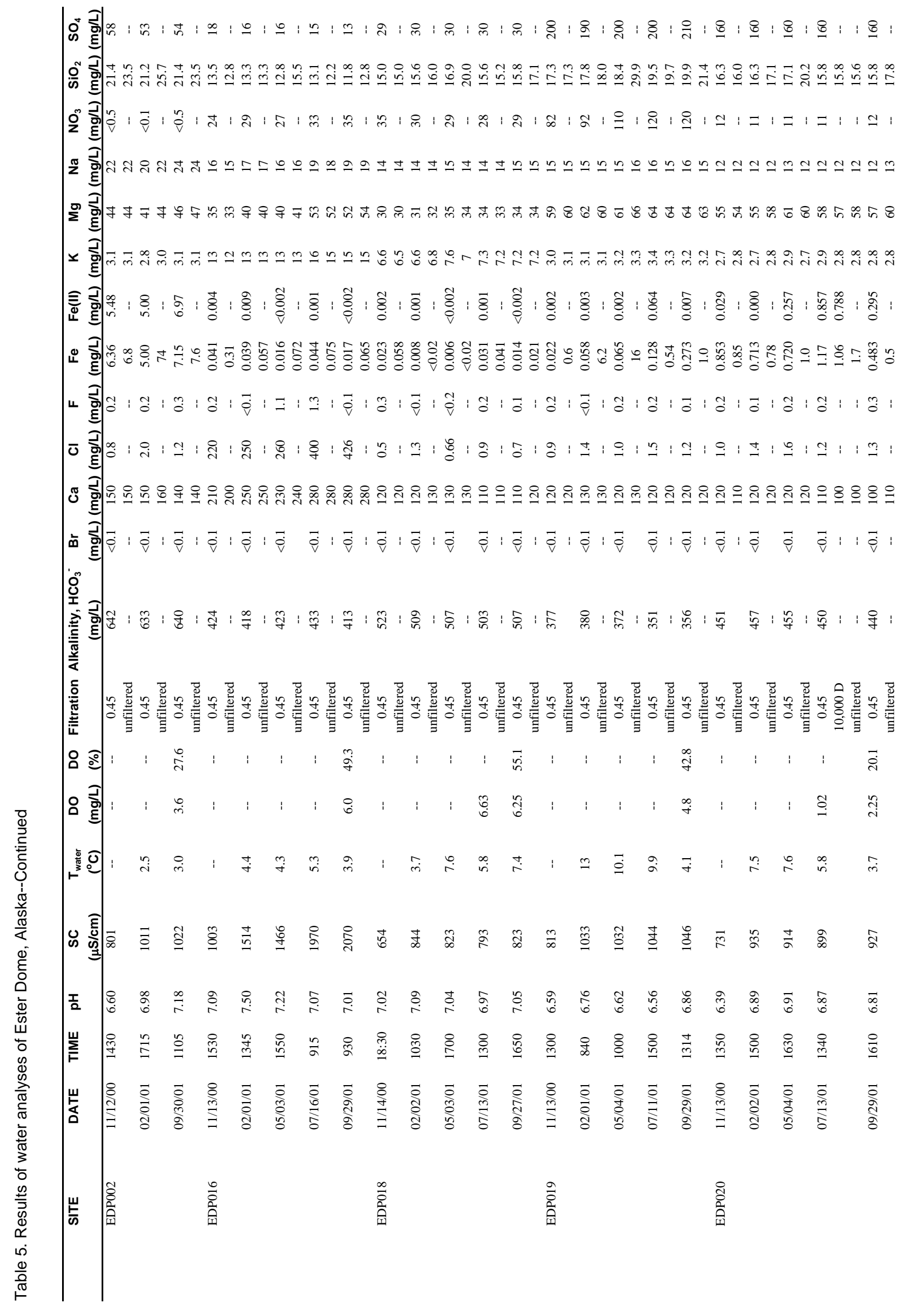




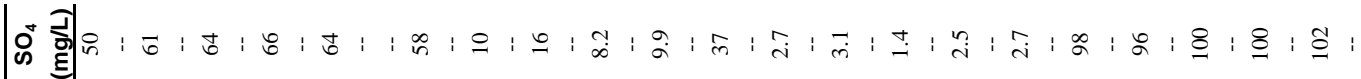

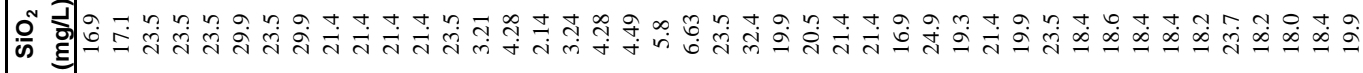

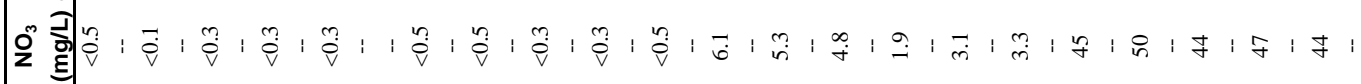

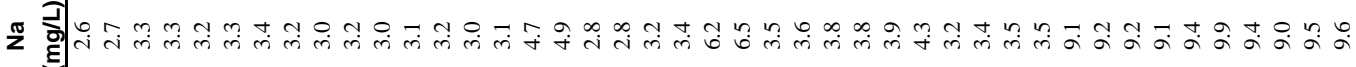

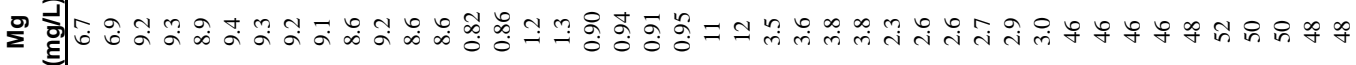
×

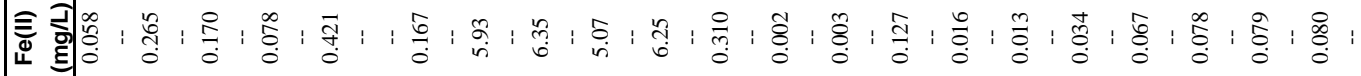

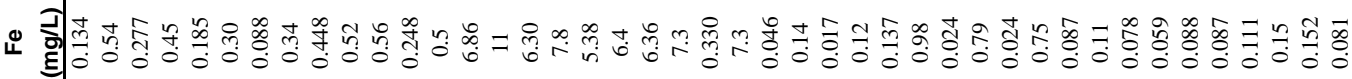

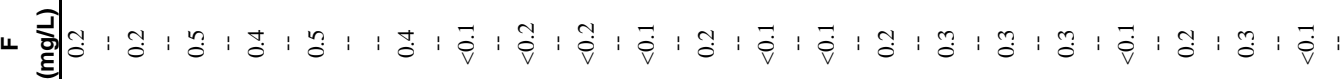

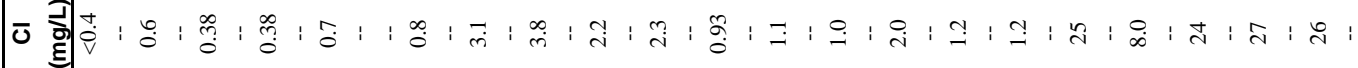
ช

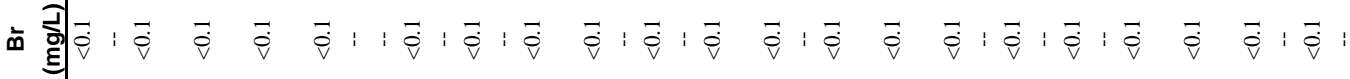
$\overbrace{0}^{\circ}$

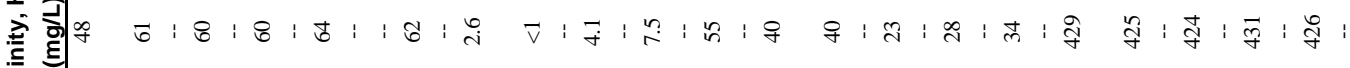

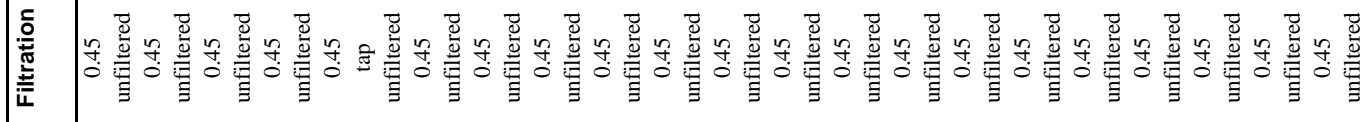
옹

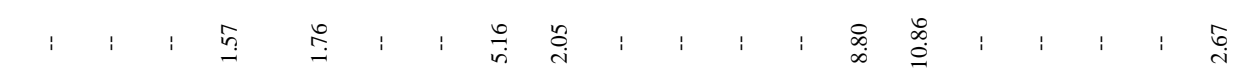

I $\quad$ की

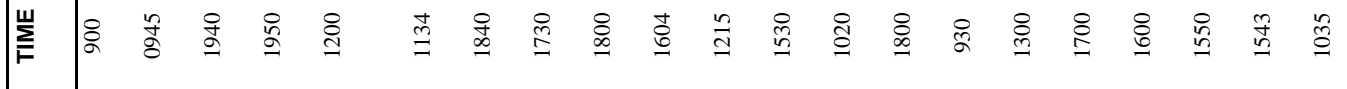

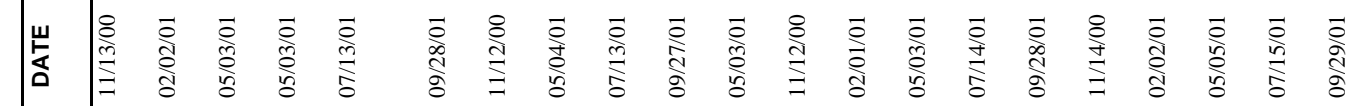

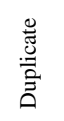

๙ัฒ

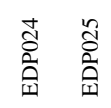

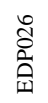




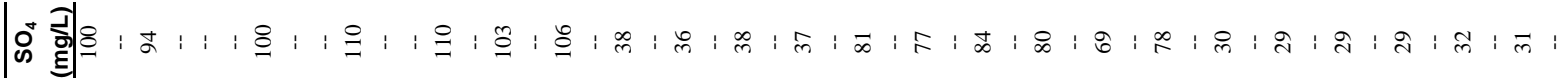

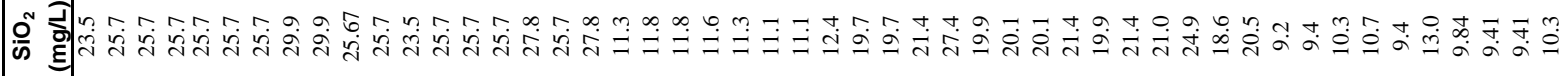

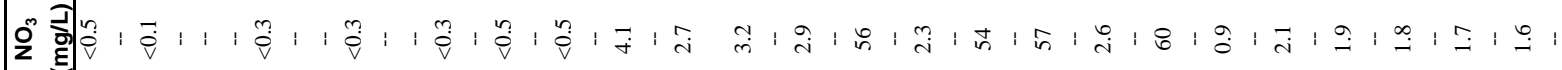

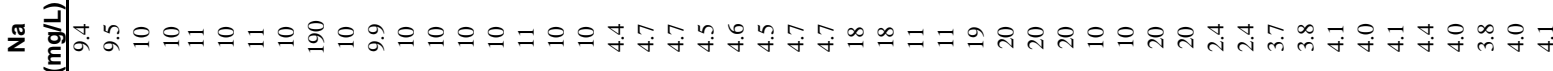

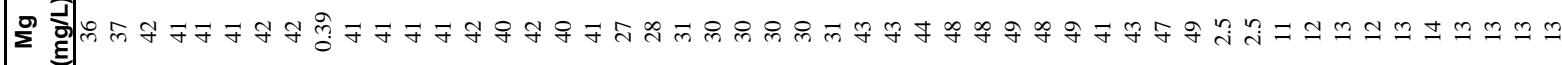

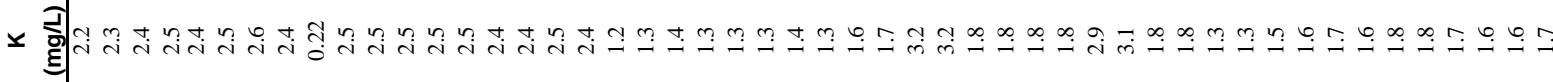

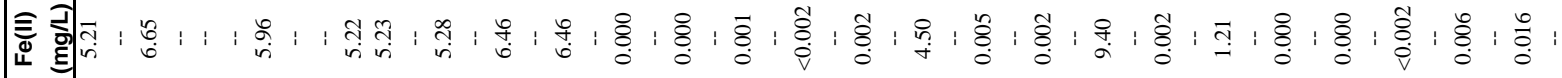

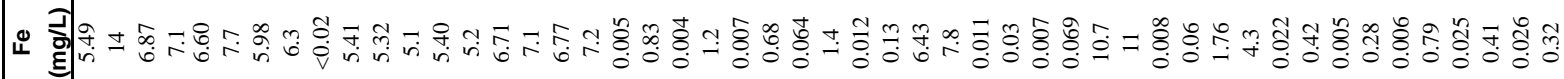



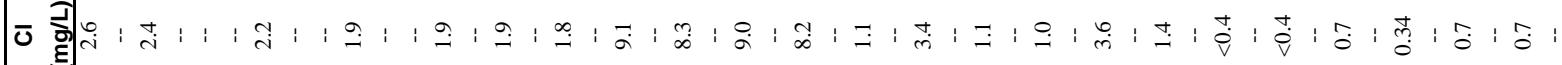

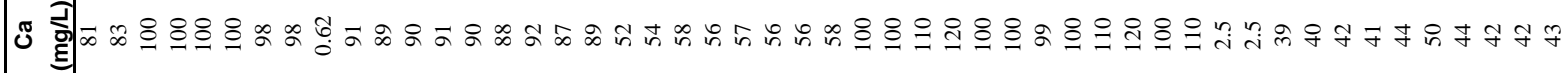

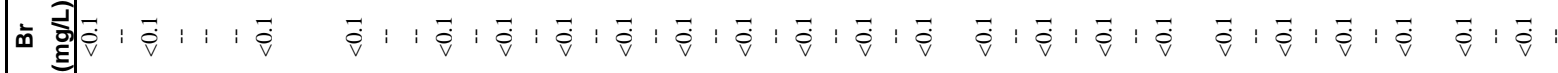

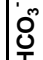

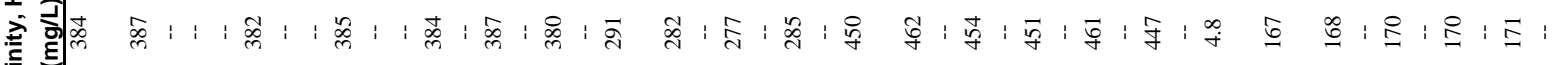

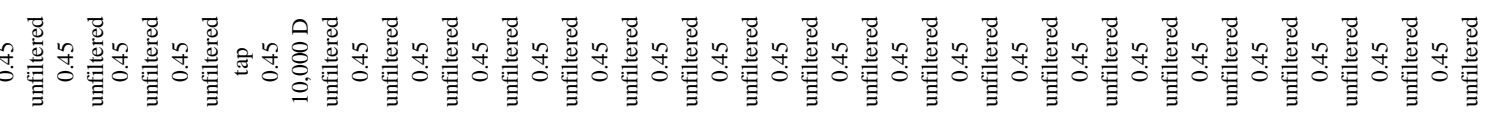

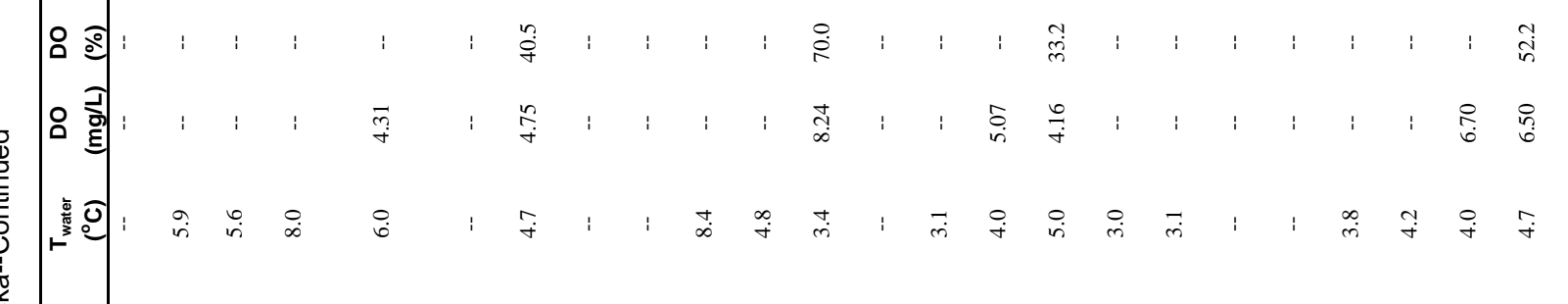

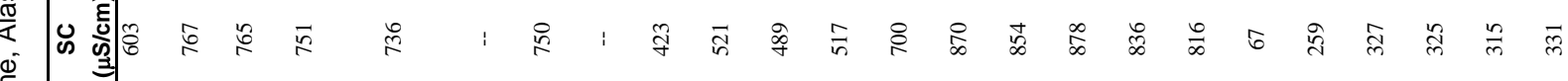
离 I $\div$ 


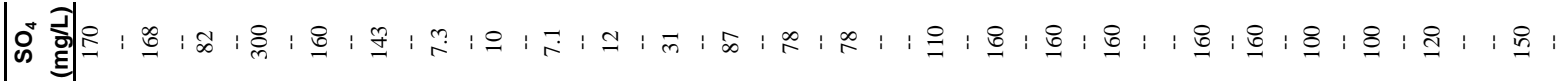



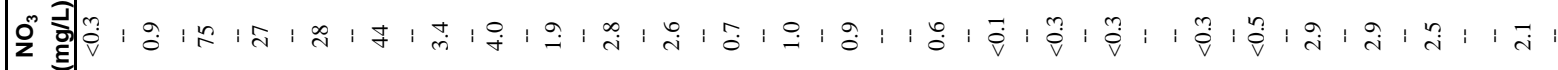

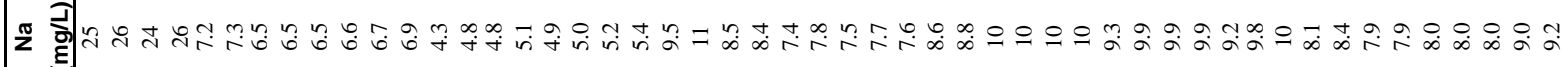

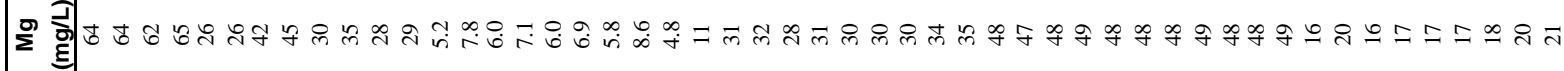

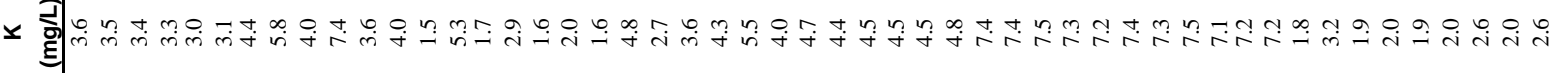

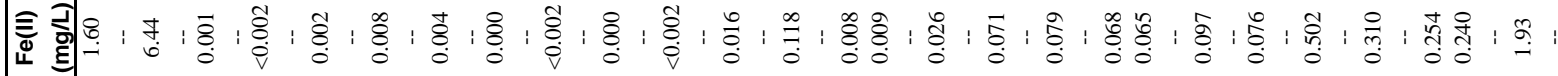

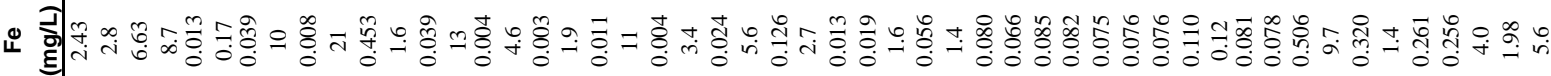

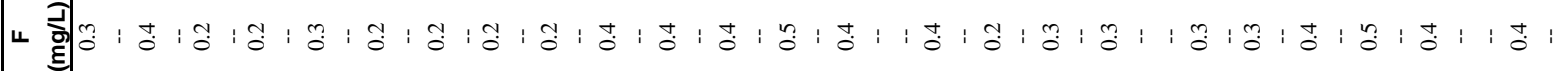

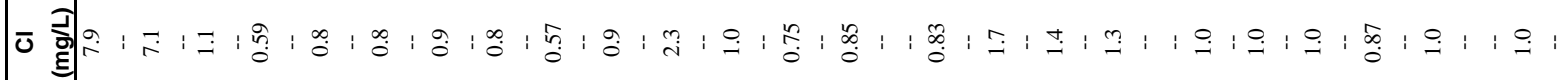

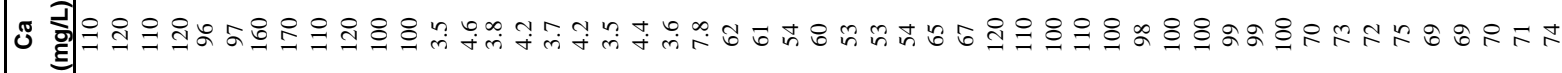

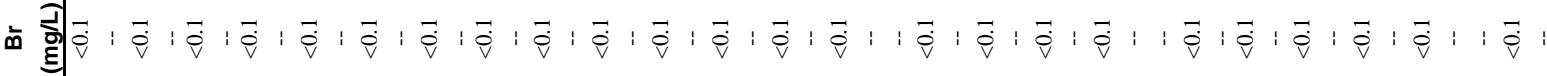
彳̊

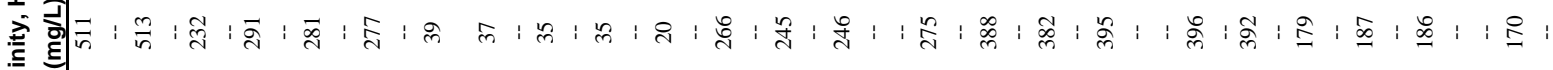
亮 क्ष

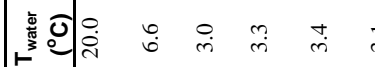

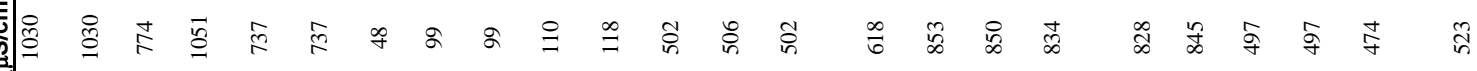

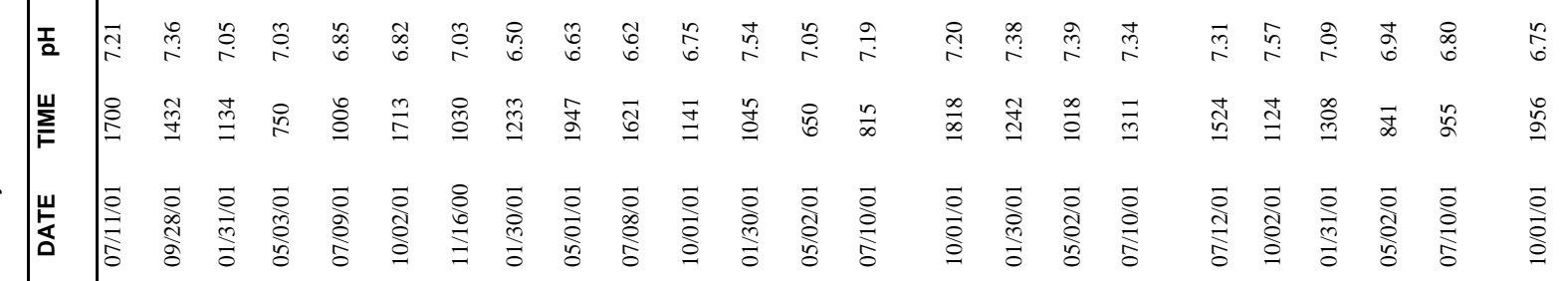




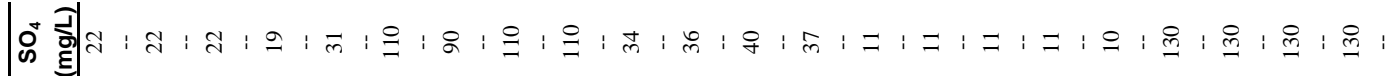

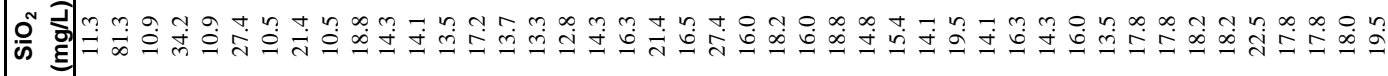

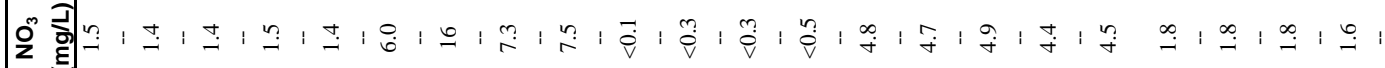

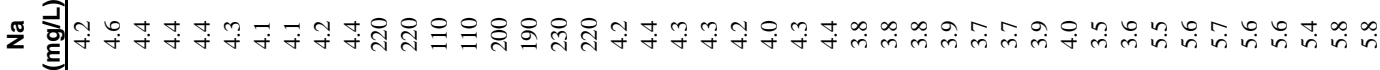

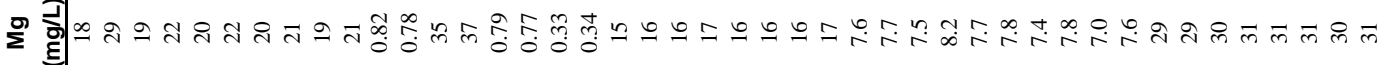

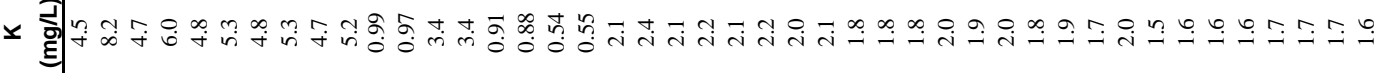

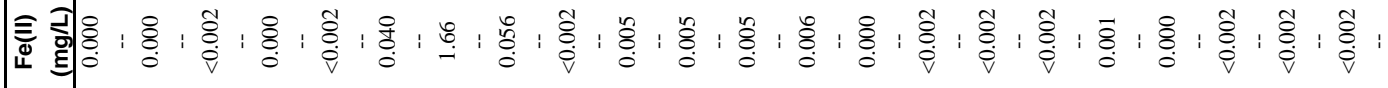

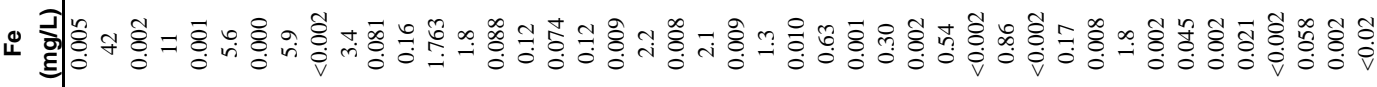

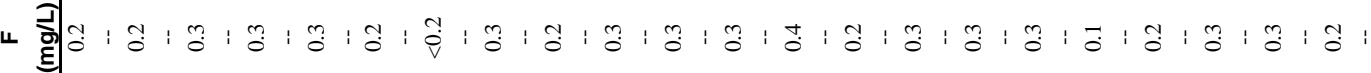

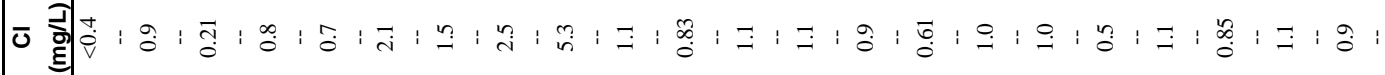

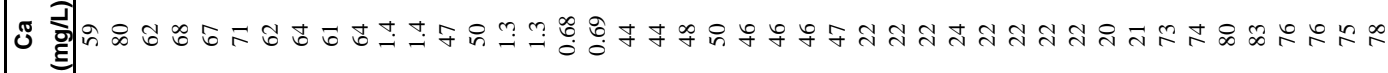

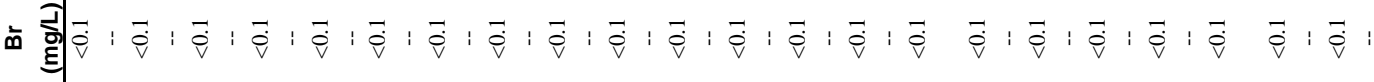
宅

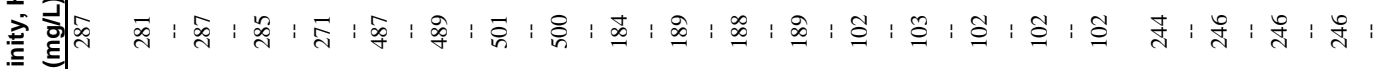

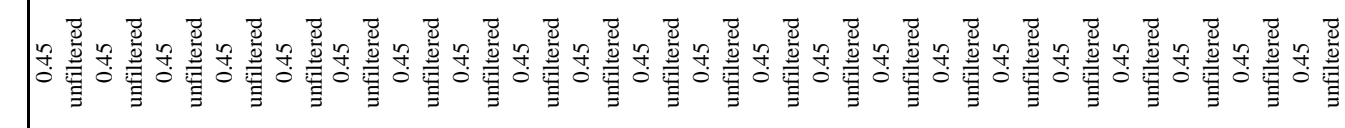

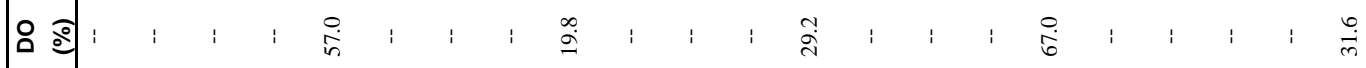

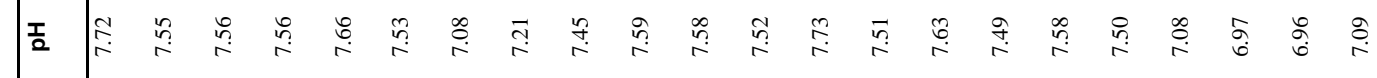




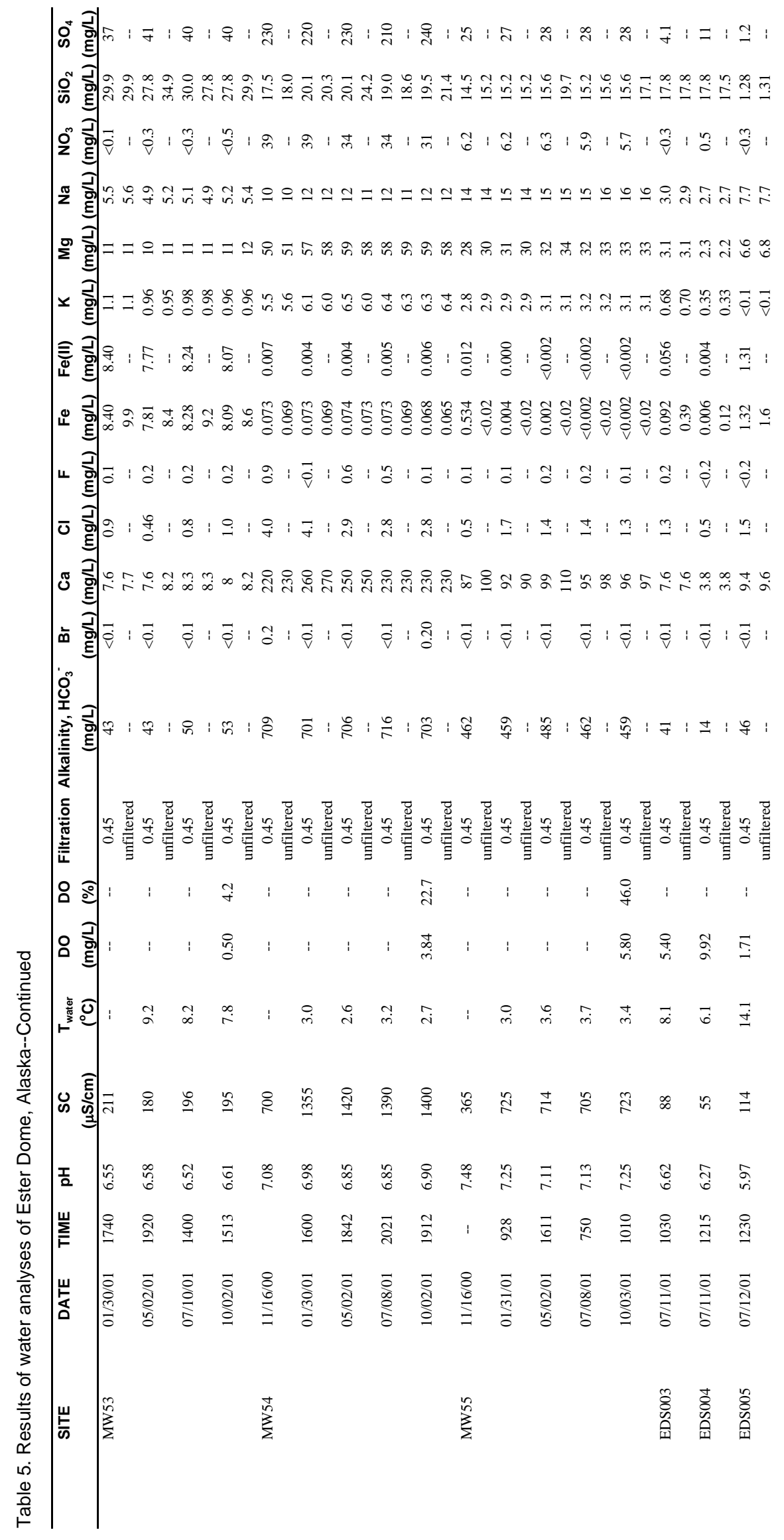




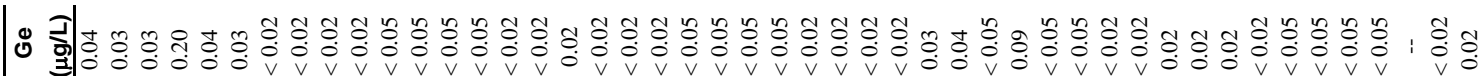
。 o

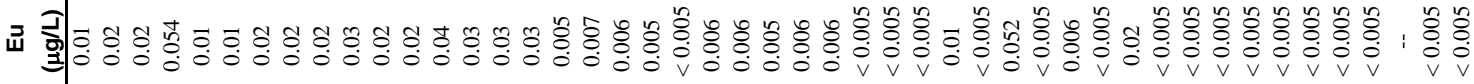

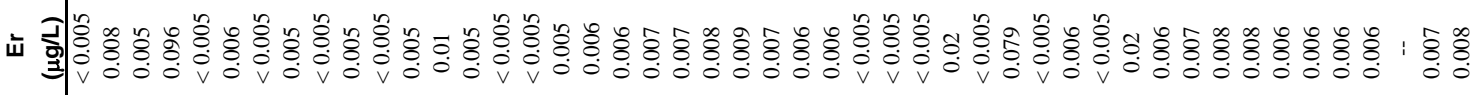

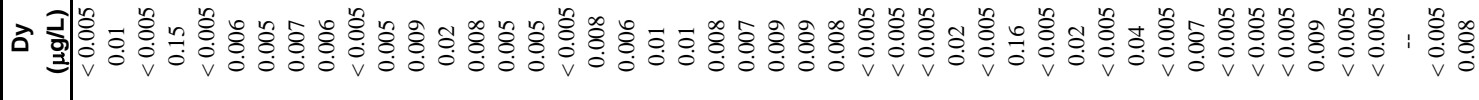

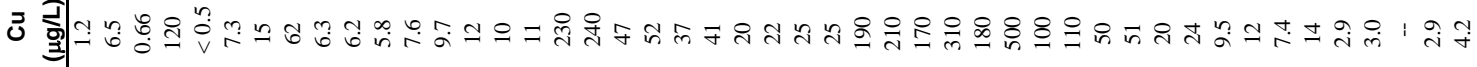

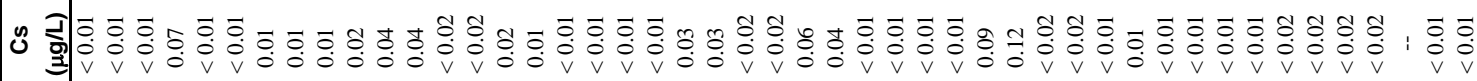
u

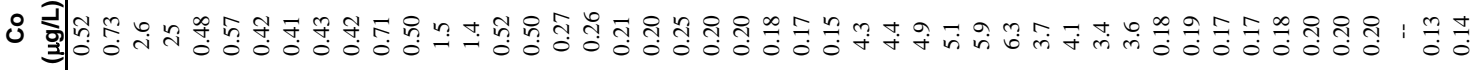

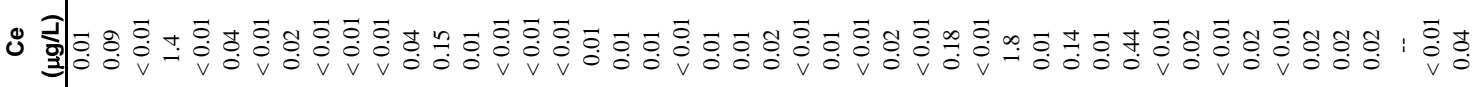

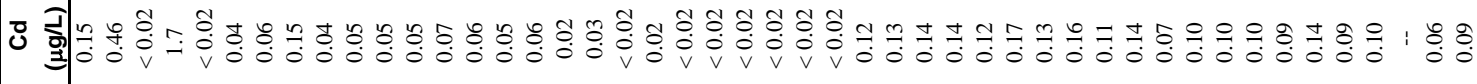

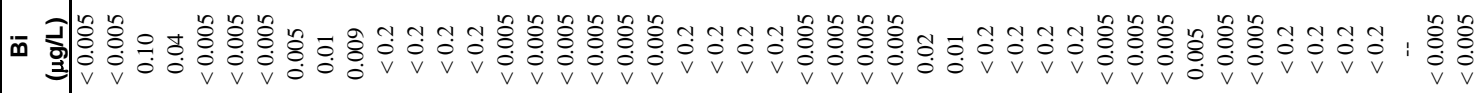
๓

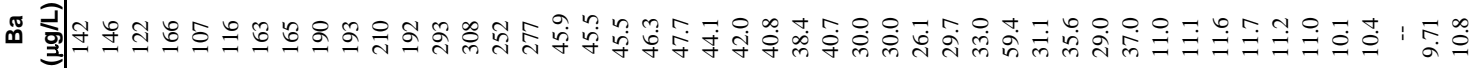

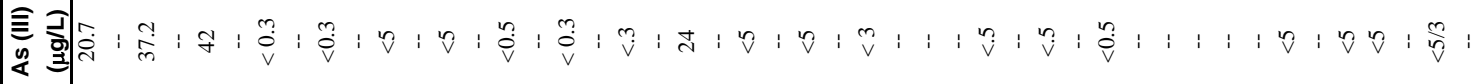

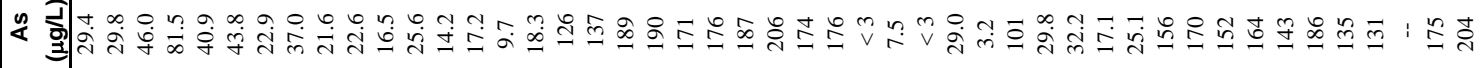

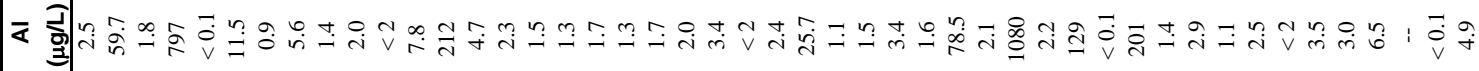

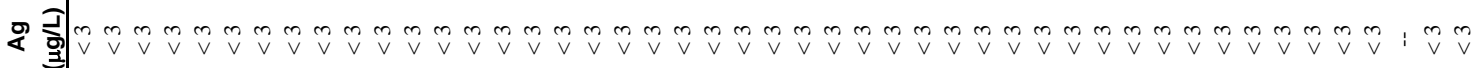
倍

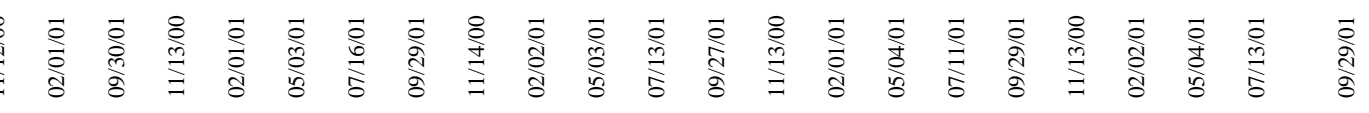
莫

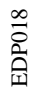

突 


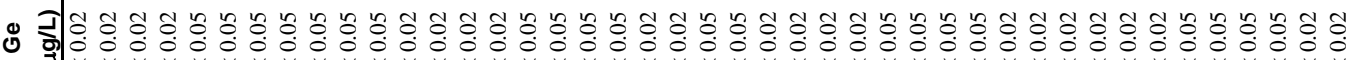

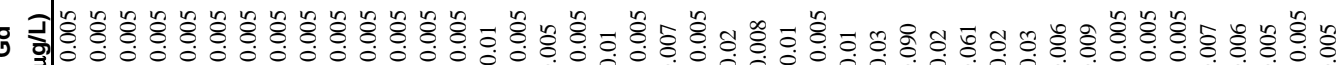

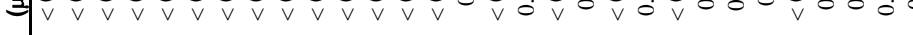

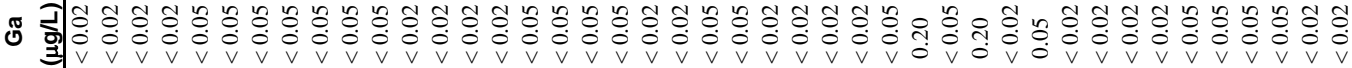
至

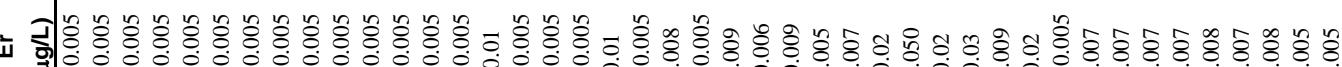

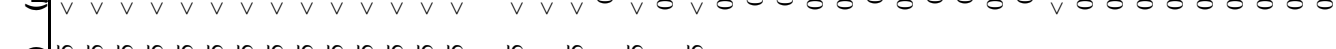

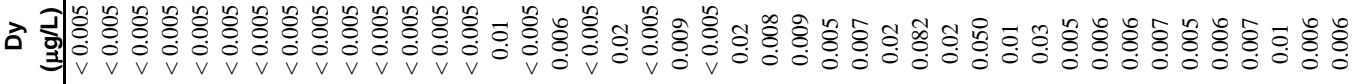

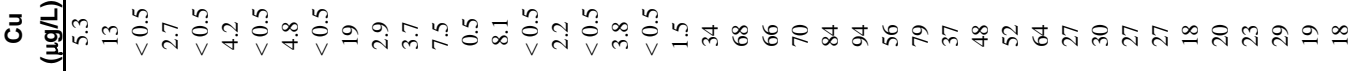
o

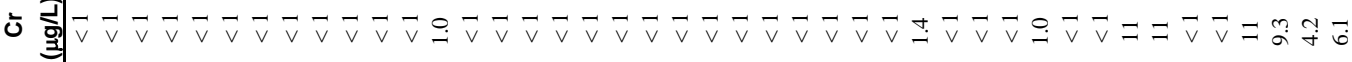

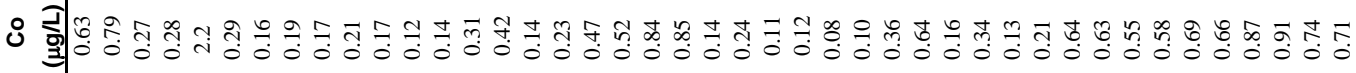

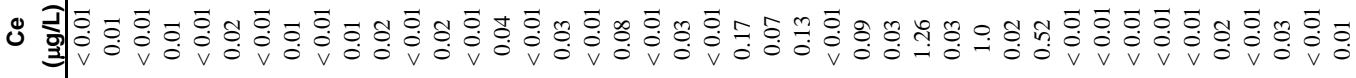

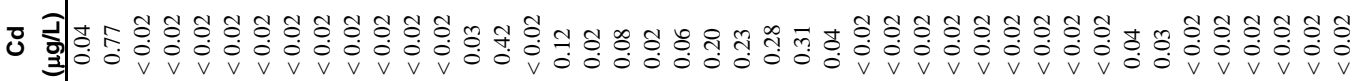

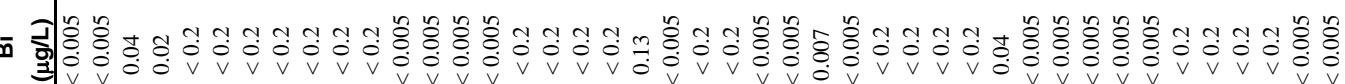

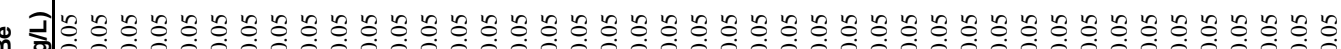

๓

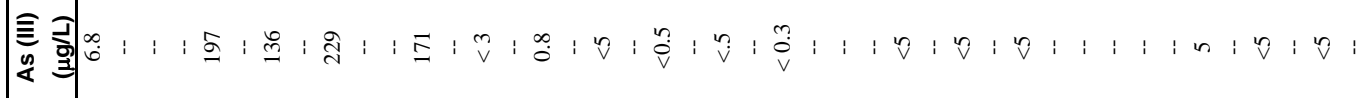

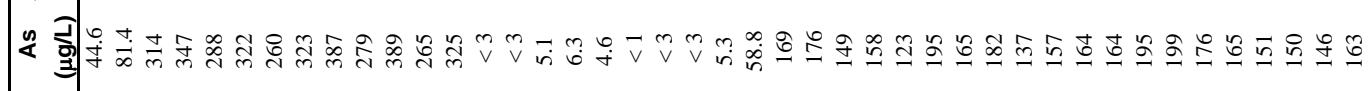

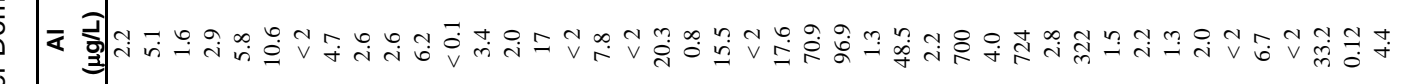

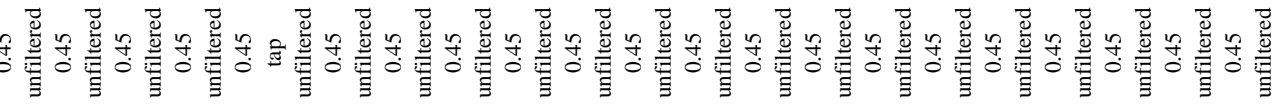


ن

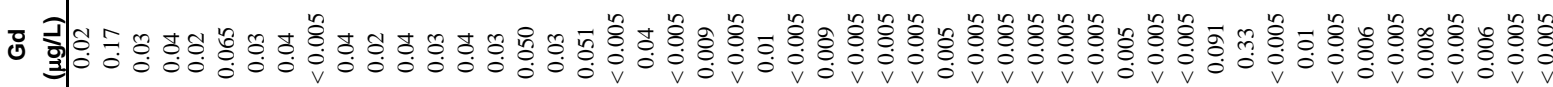
o

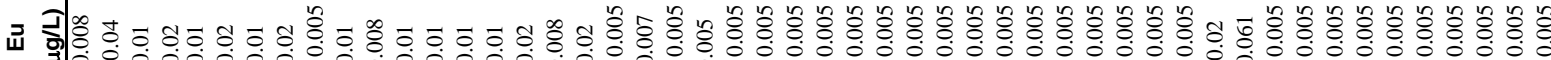

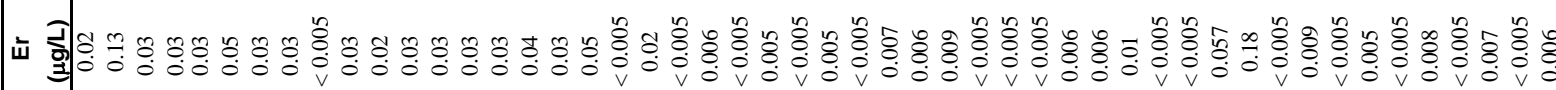
ح

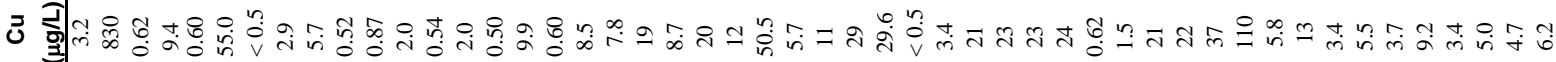
u

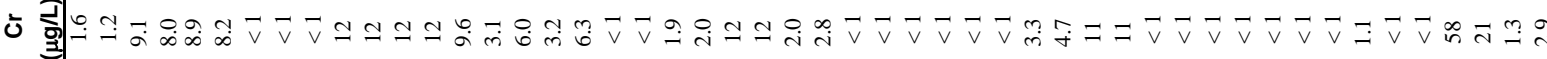

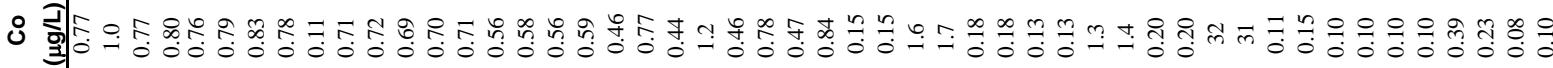

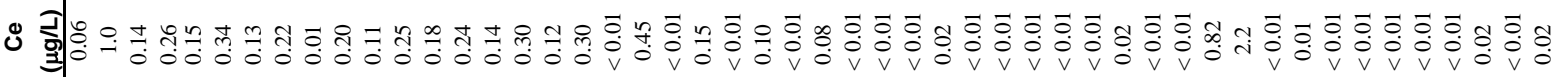

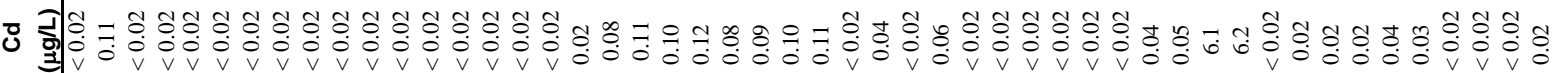
可 ๓

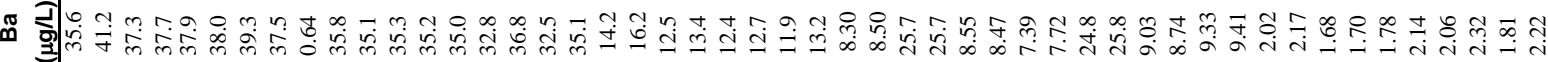

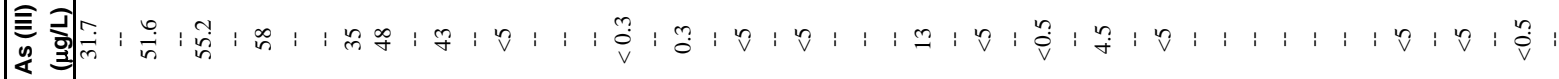

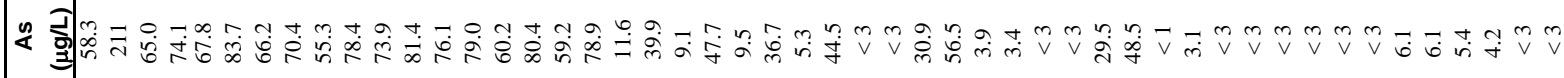

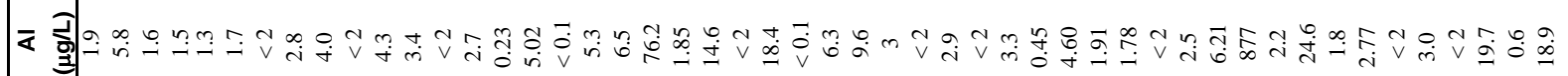

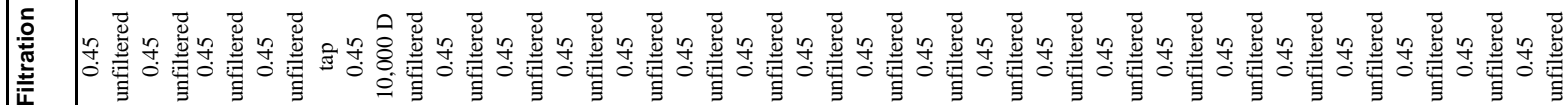

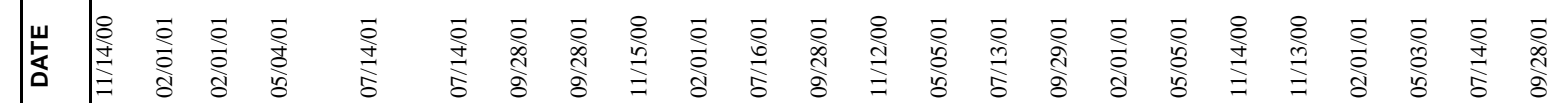
预 $\stackrel{\substack{0 \\ \frac{0}{0}}}{\stackrel{0}{\circ}}$ 章

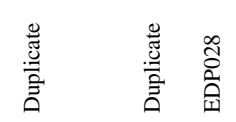

잉

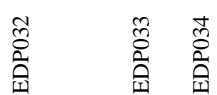




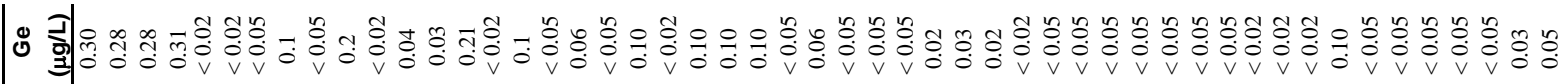

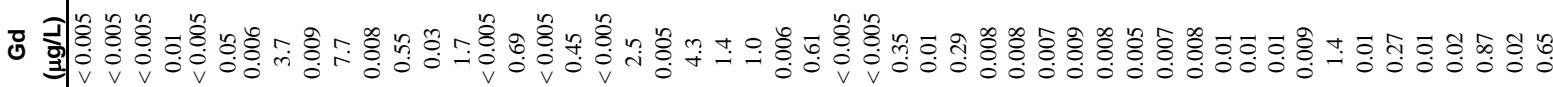

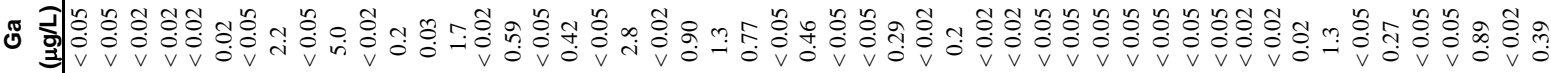

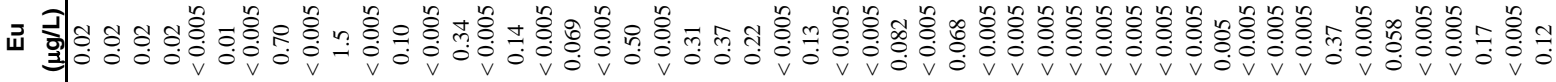

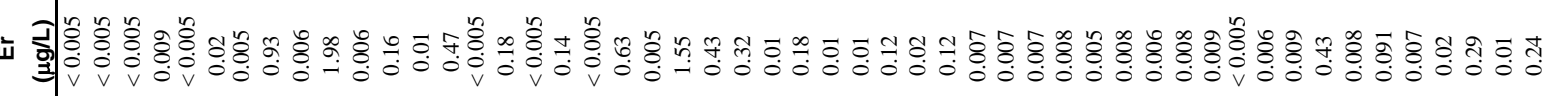

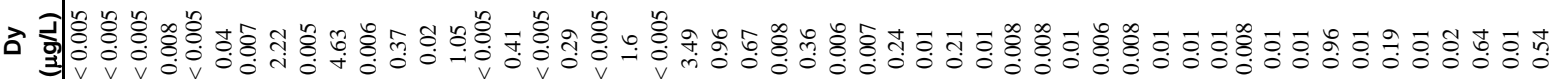

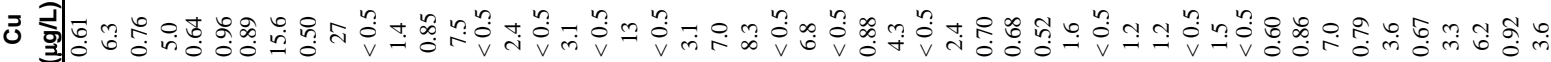

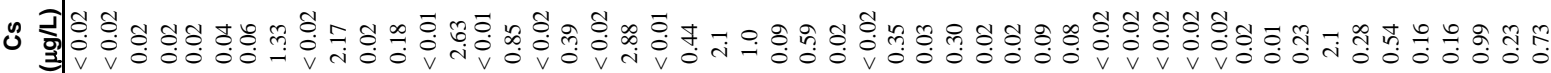

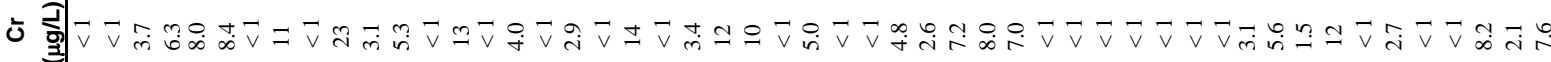

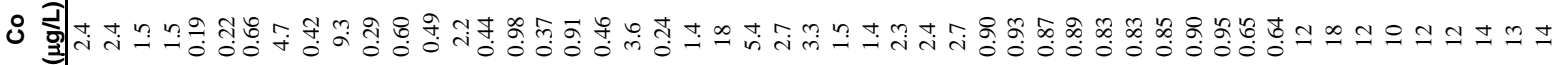

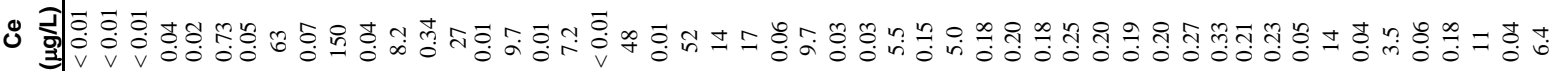

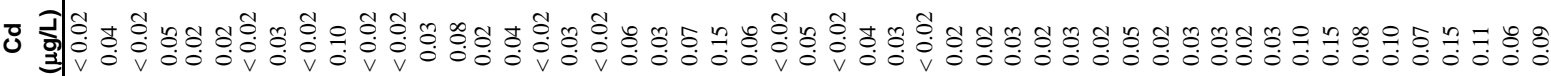

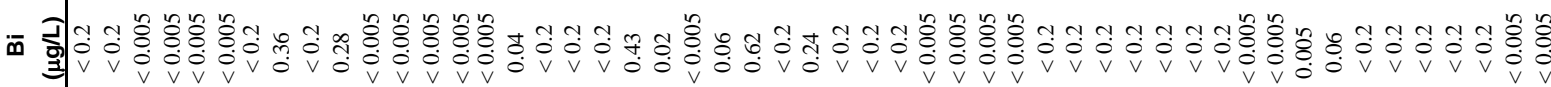

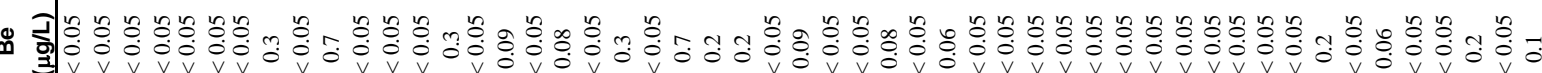

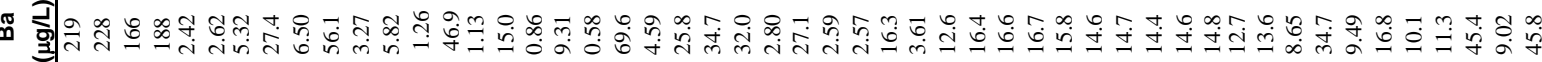

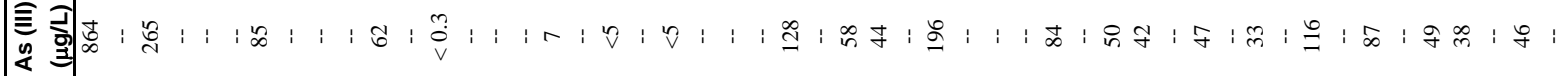

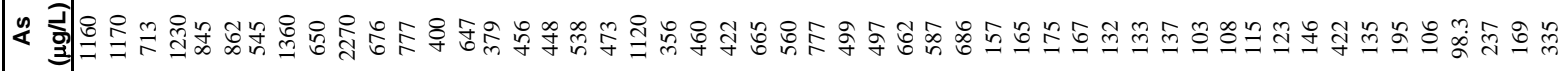

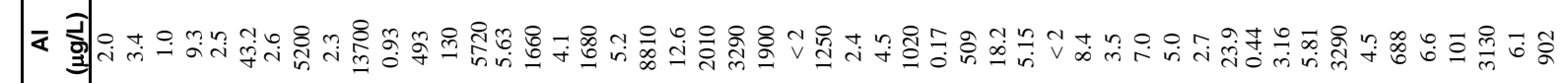

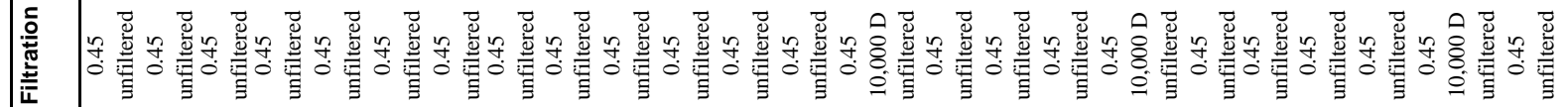
范 


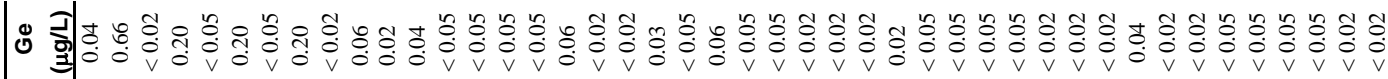

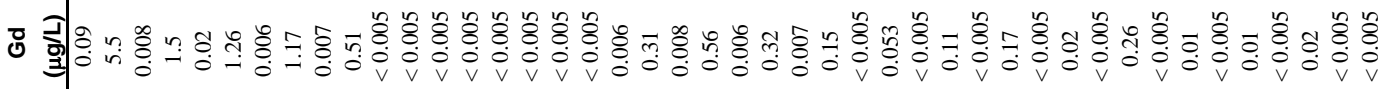

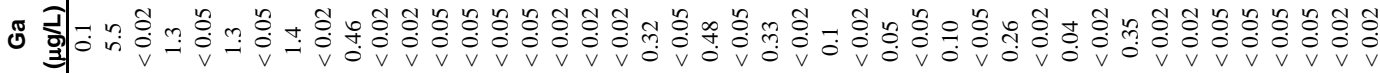

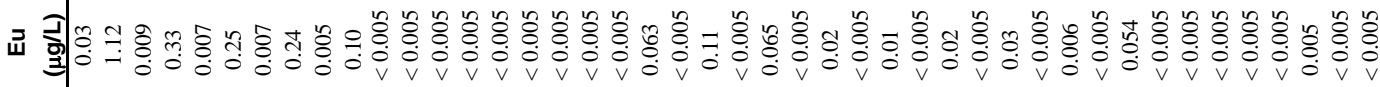

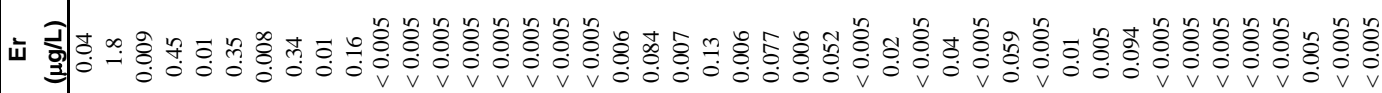

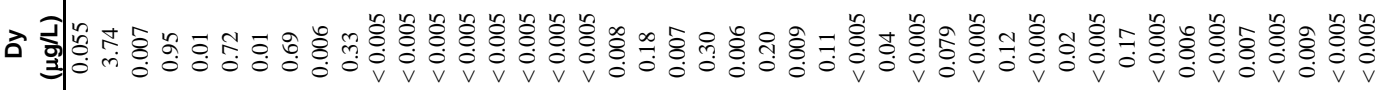

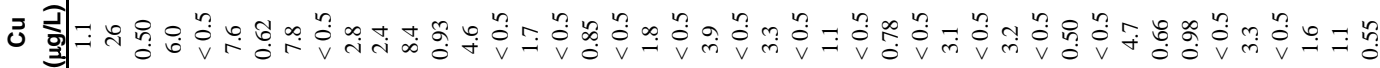

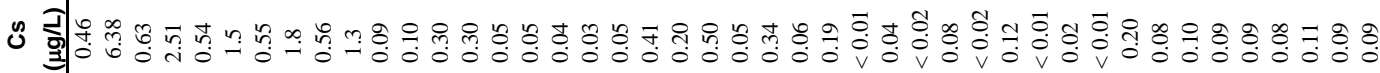

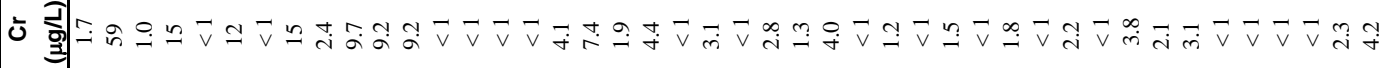

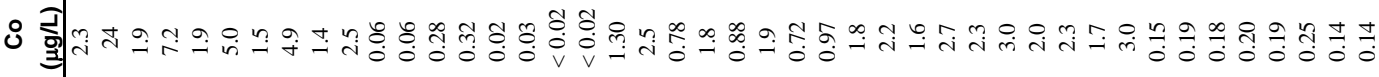

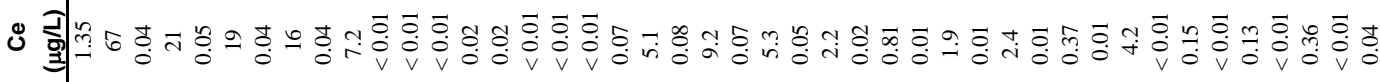

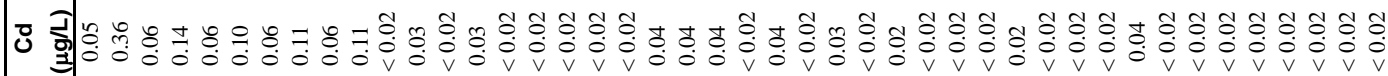

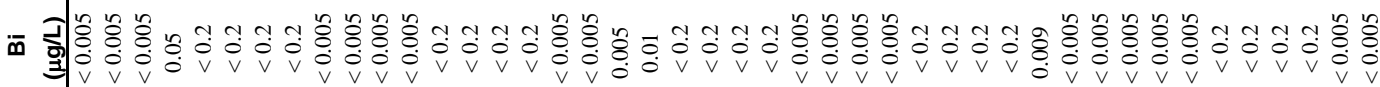



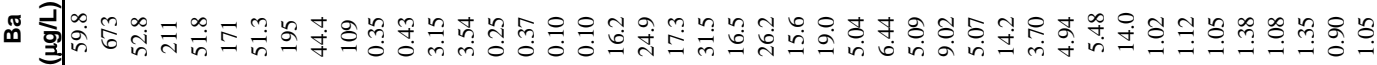

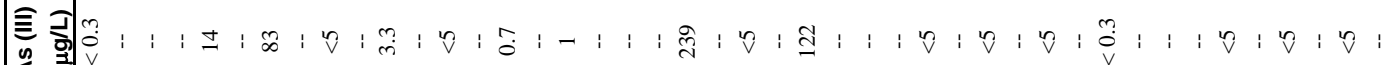

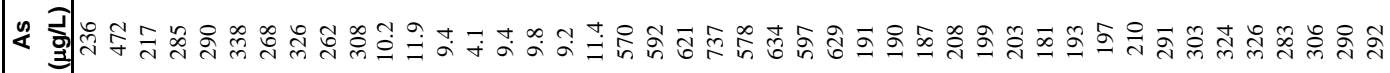

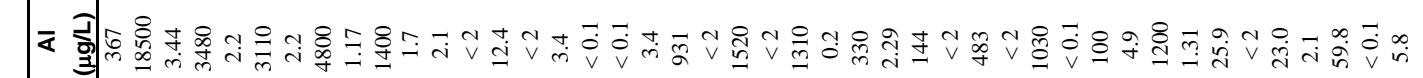

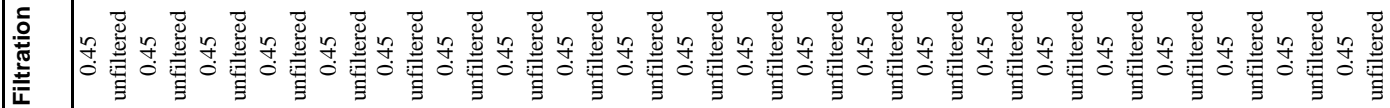

MHMMUMMUM 


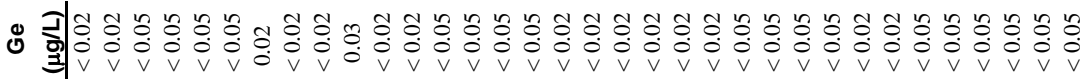

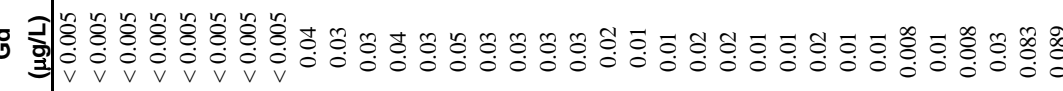

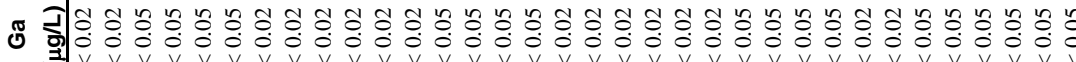

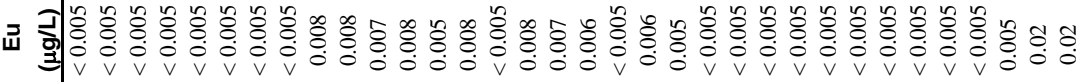

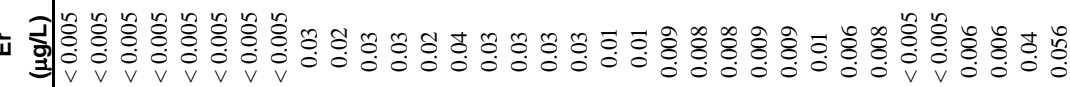

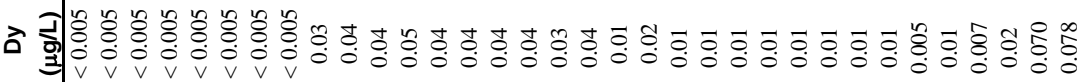

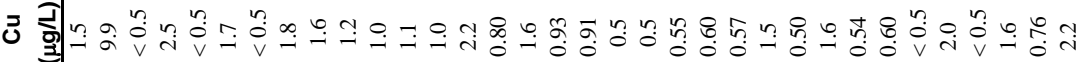

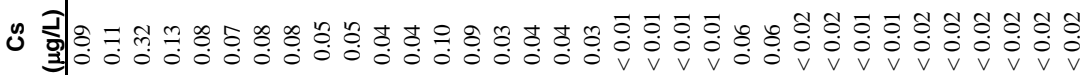

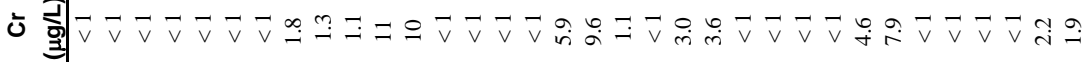

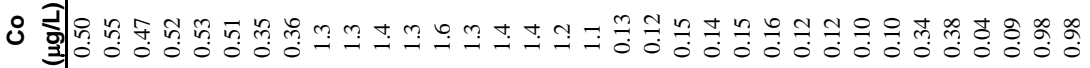

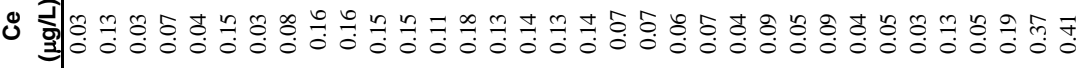

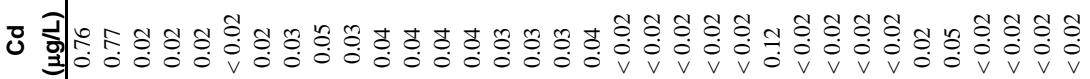

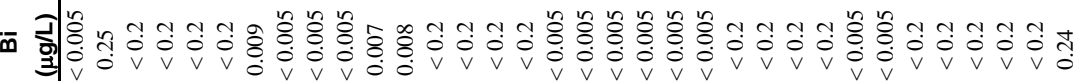

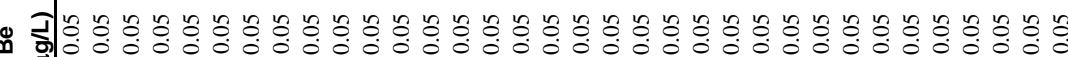

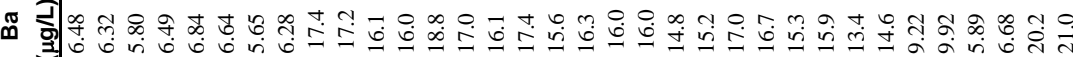

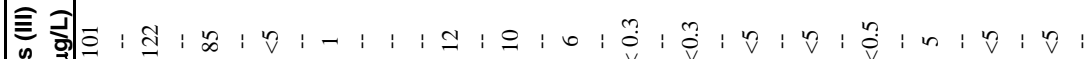

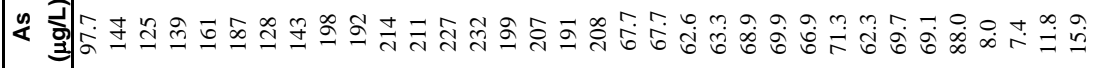

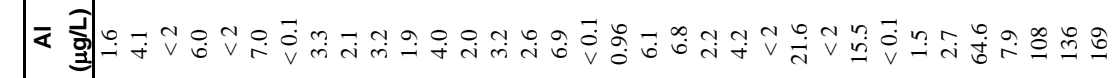

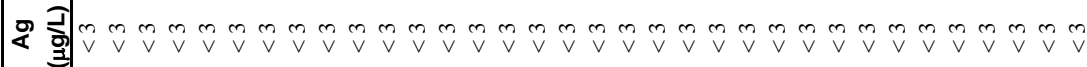

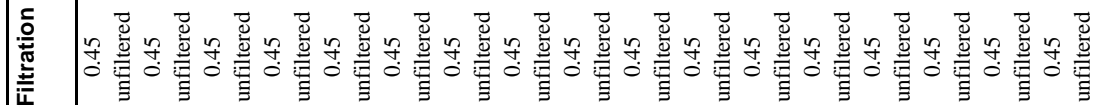

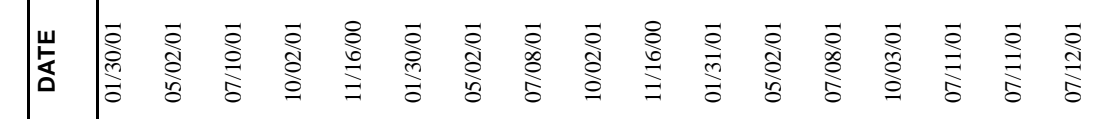

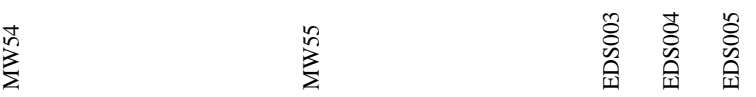




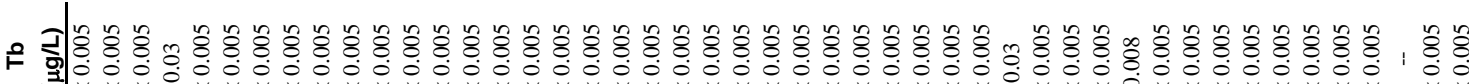

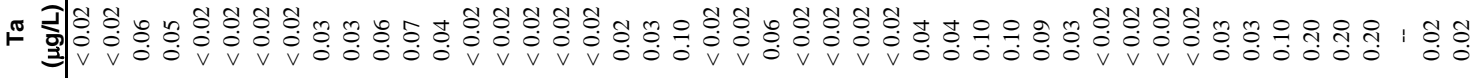

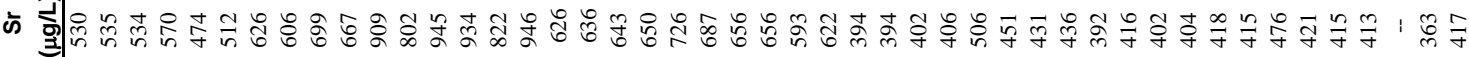

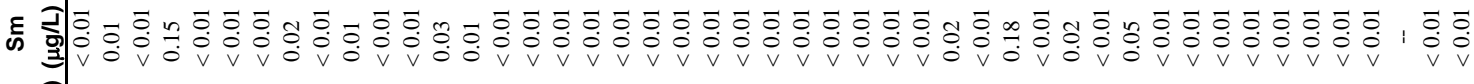

๗)

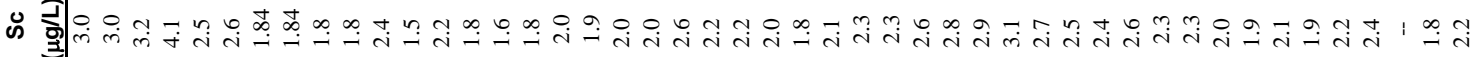

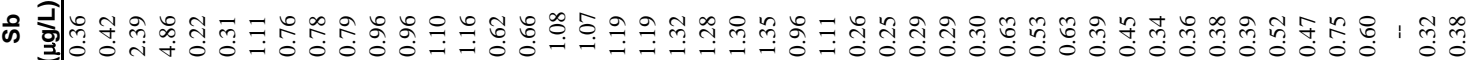

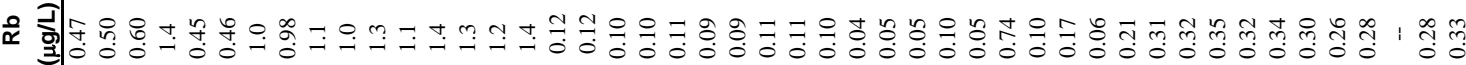

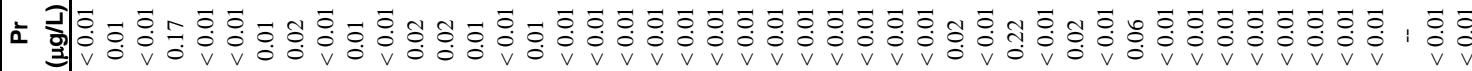

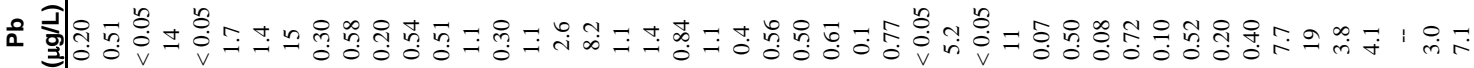

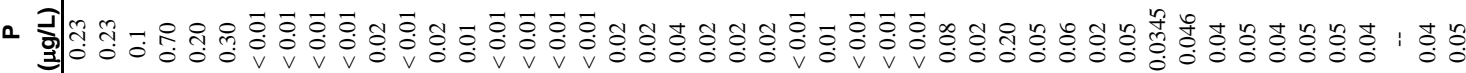
z z Z

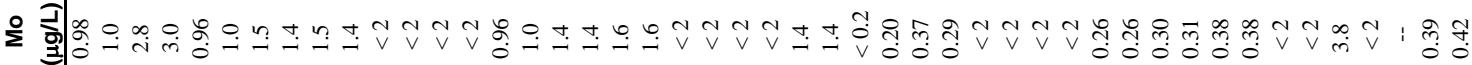

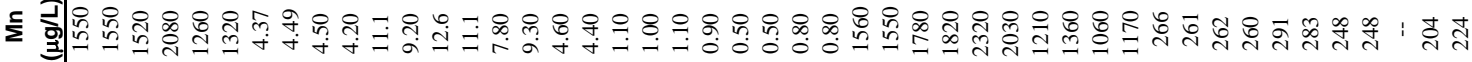

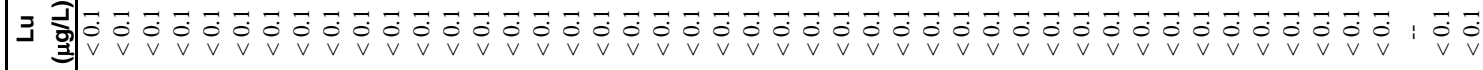
ت

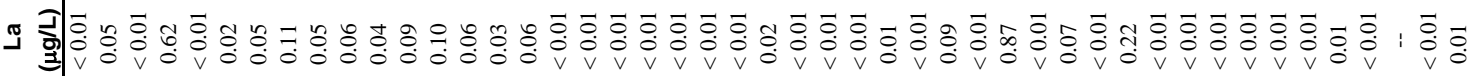
×

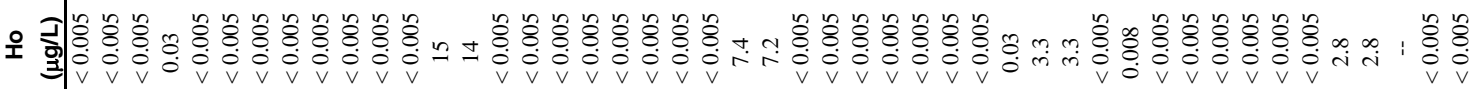

旁

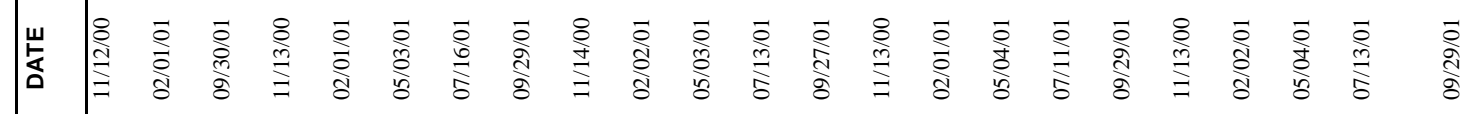

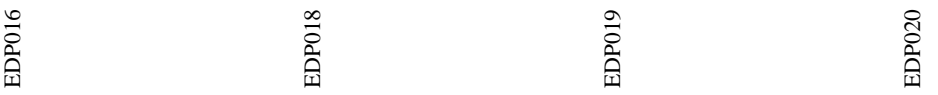




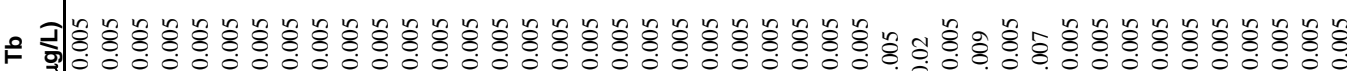

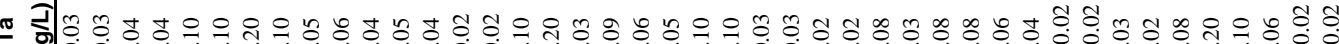

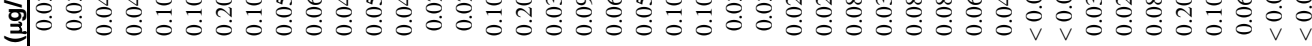

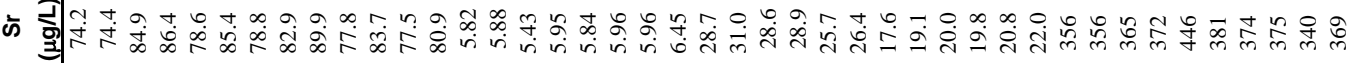

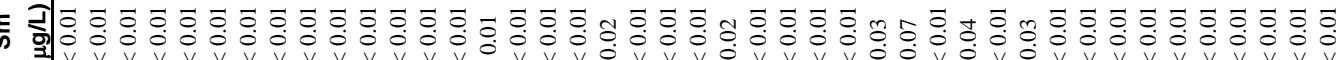
๗

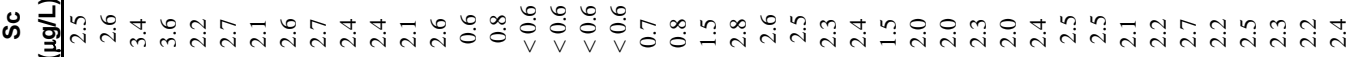
๘

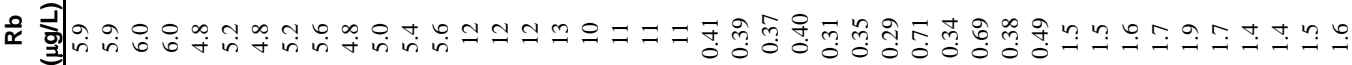

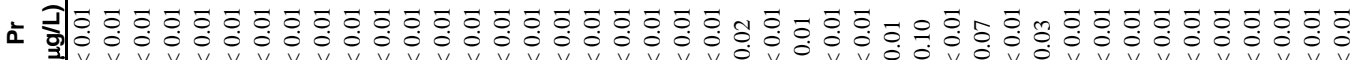

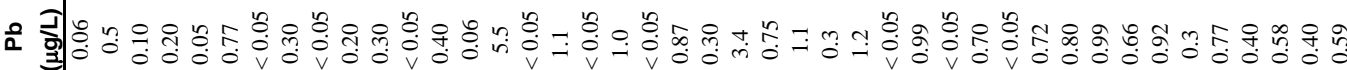

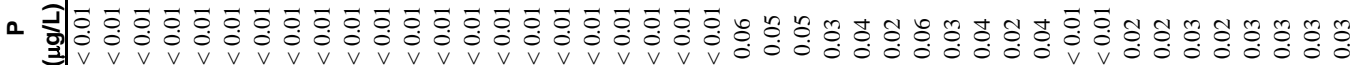

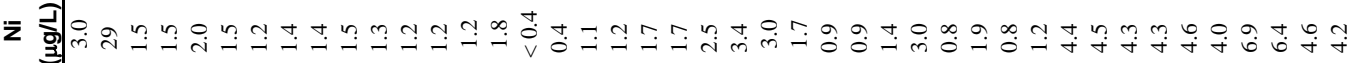

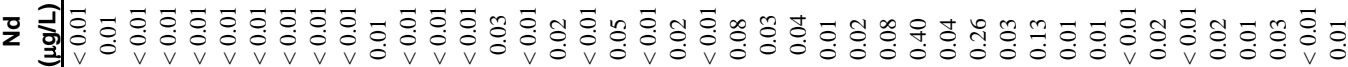

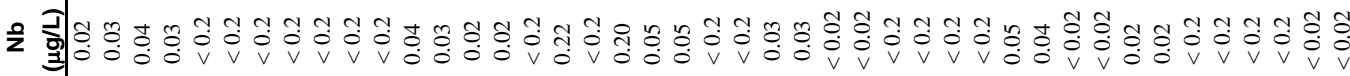

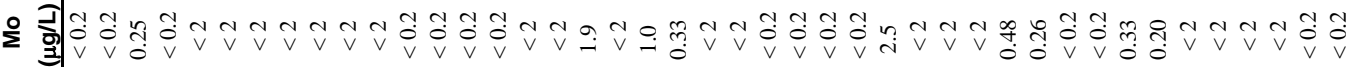

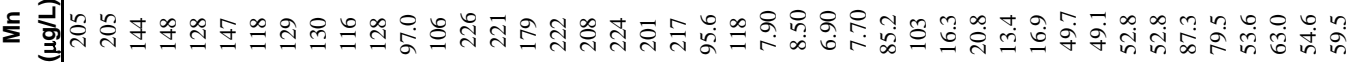

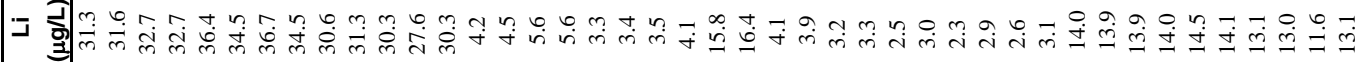

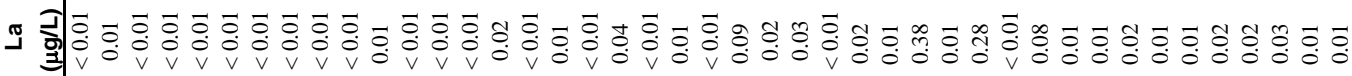

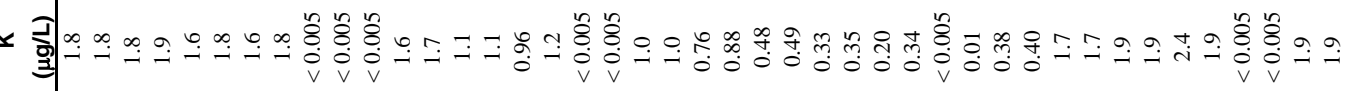

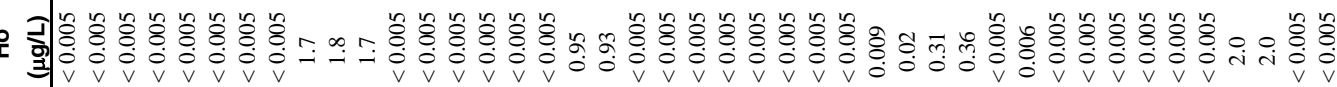

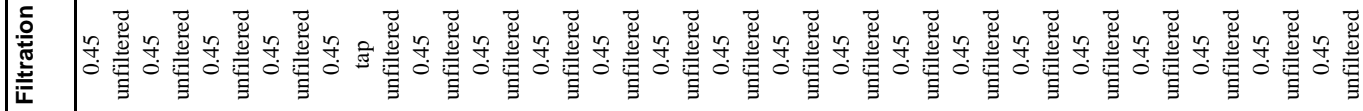

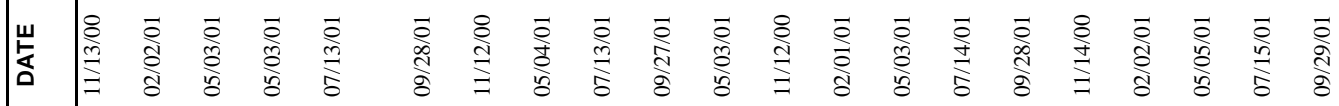
产 กิ

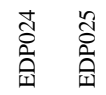

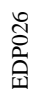




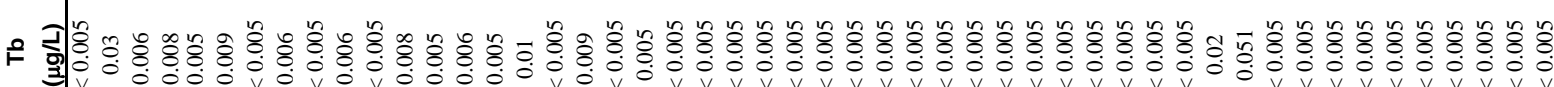

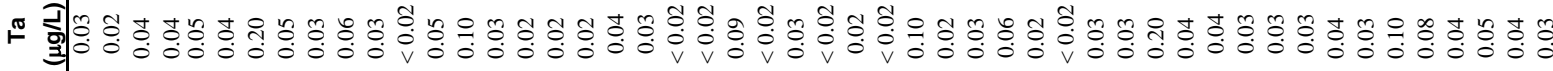

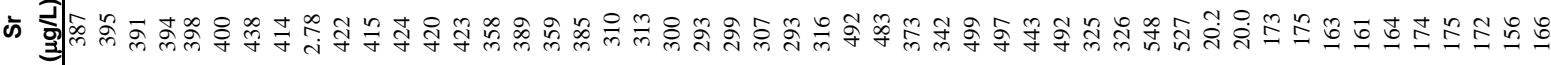

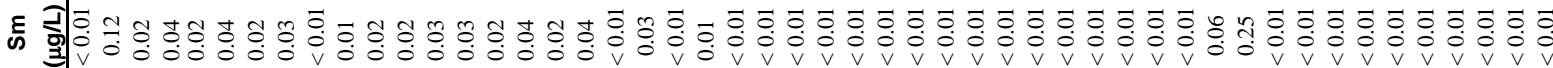
ஸึ

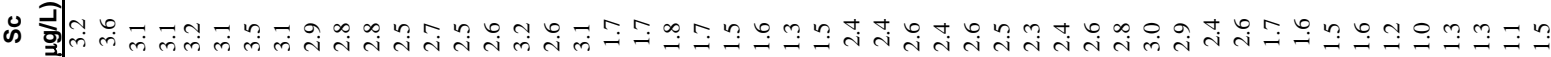

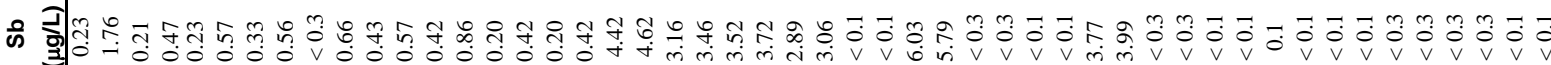

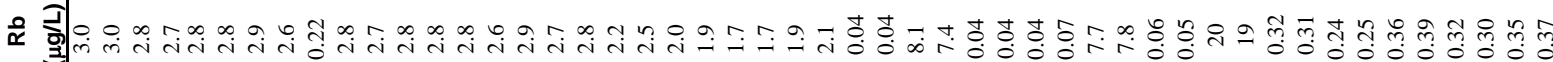

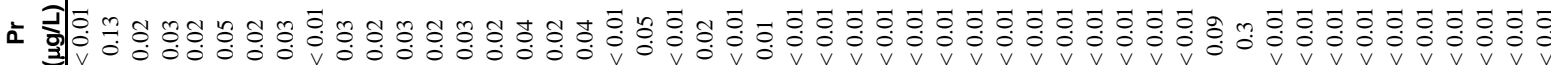

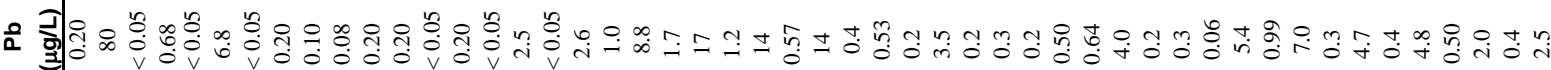

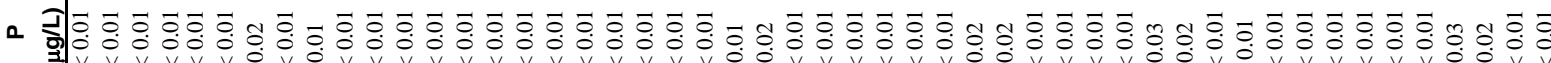

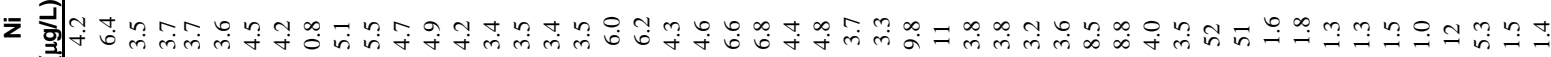

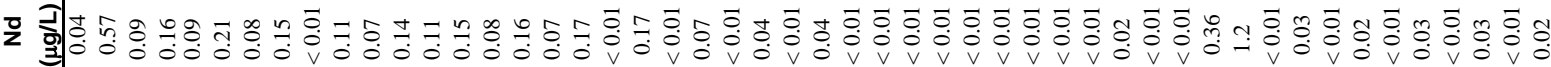

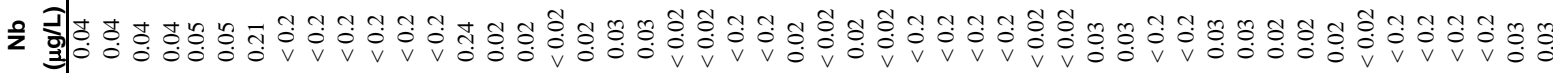
胥

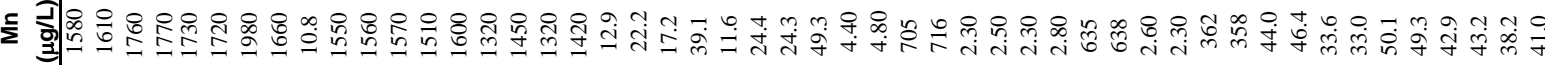

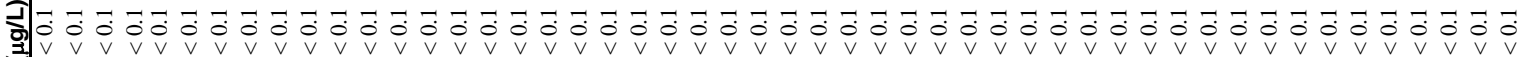

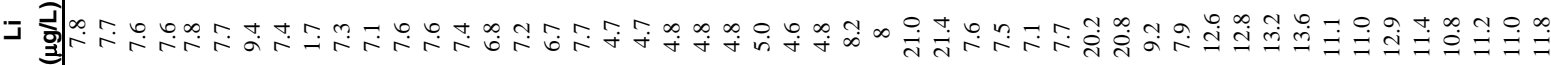

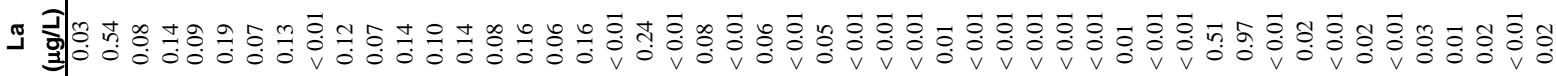

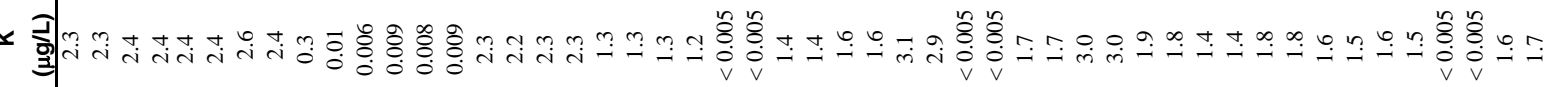

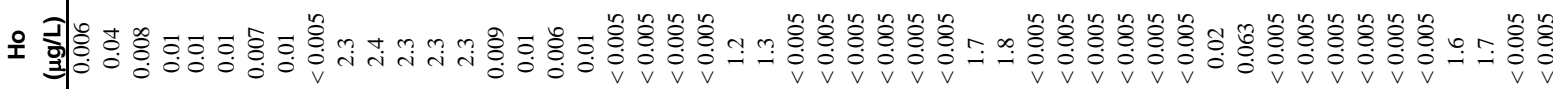

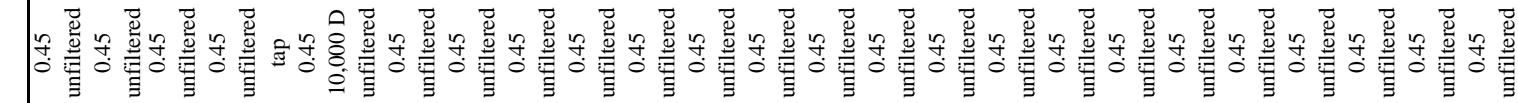
崖

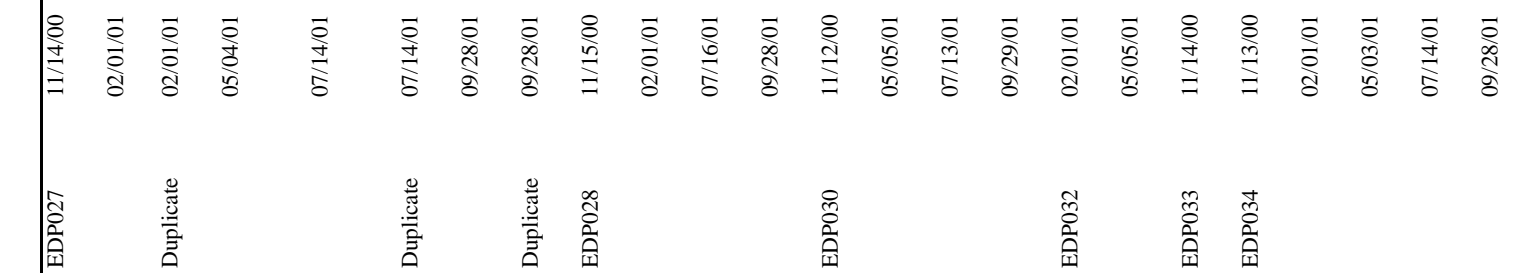






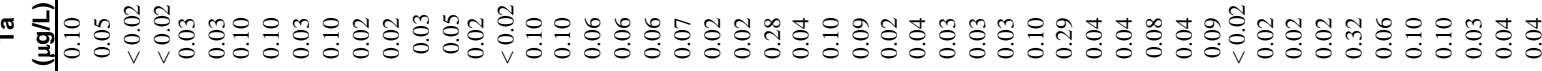

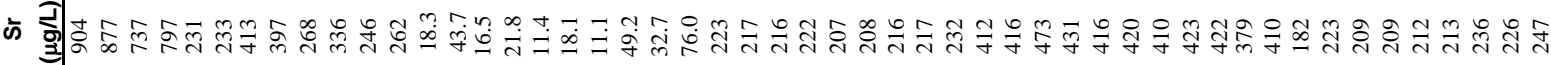

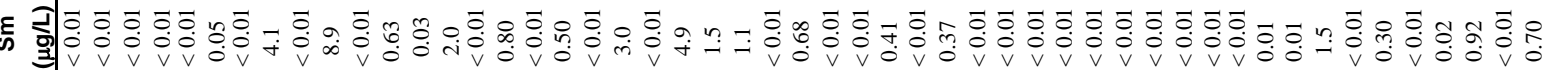

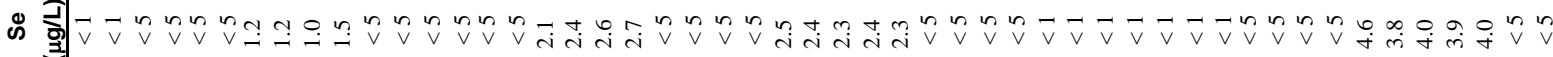

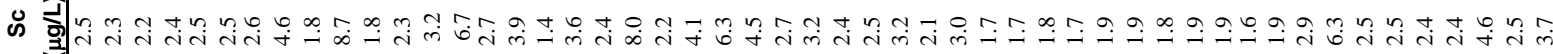

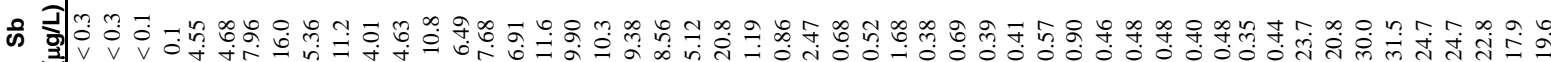

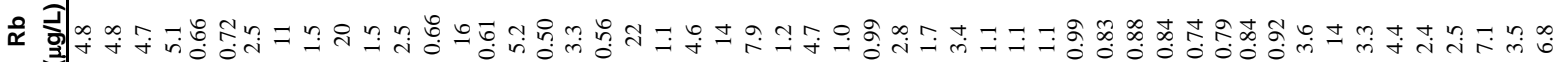

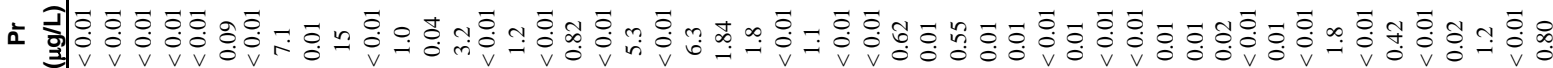

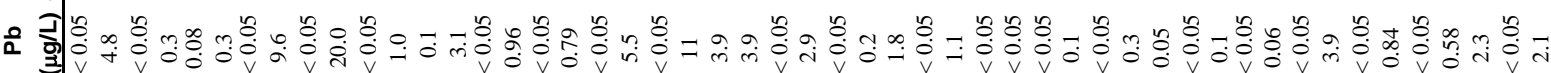

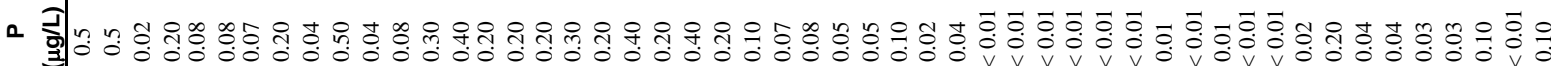
之

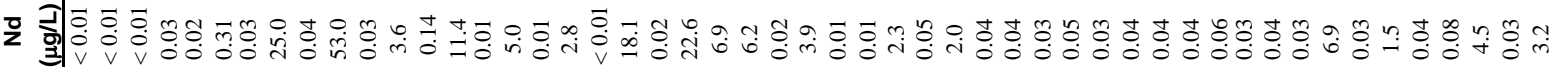

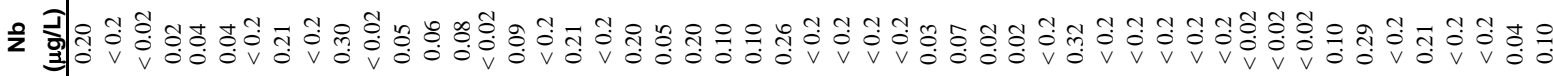

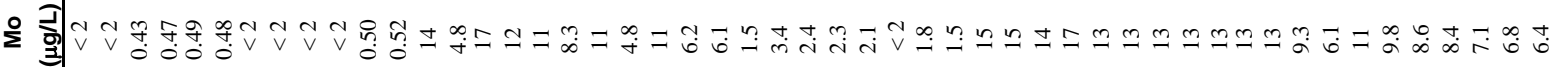

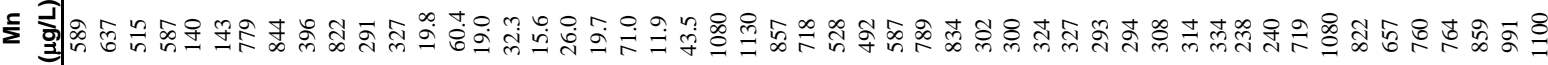

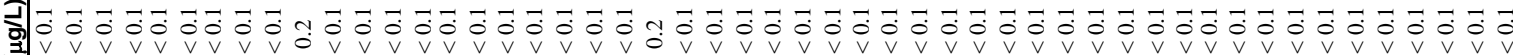
ت エ

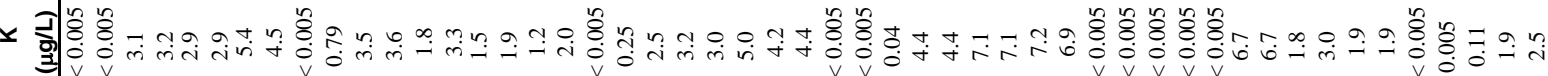

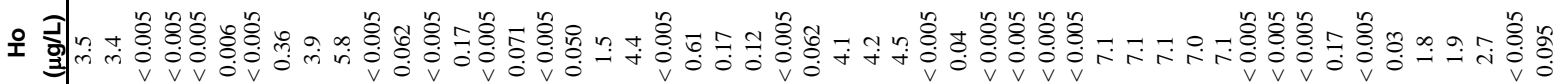

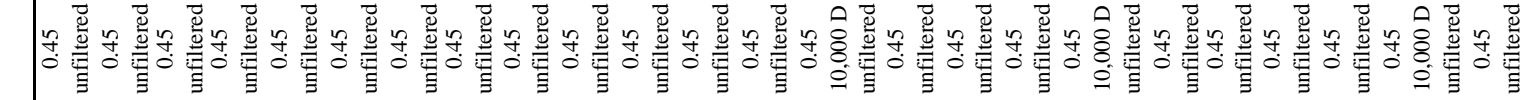

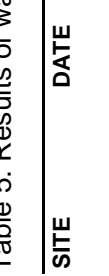

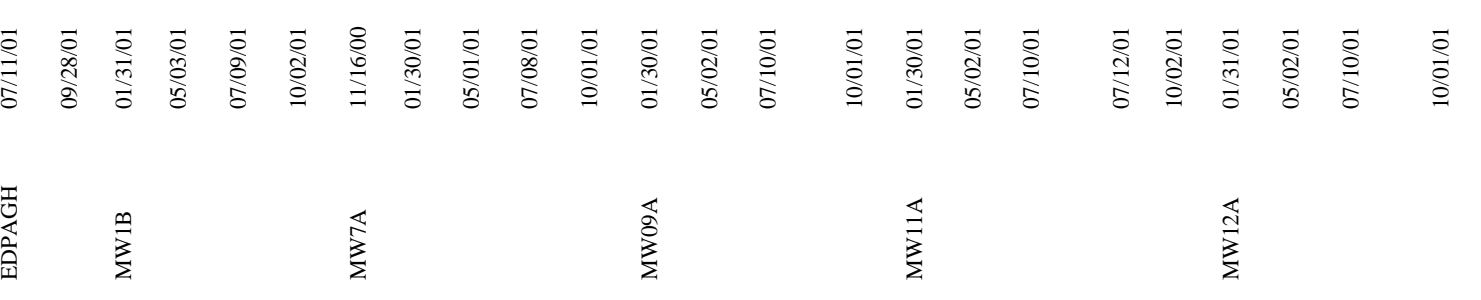




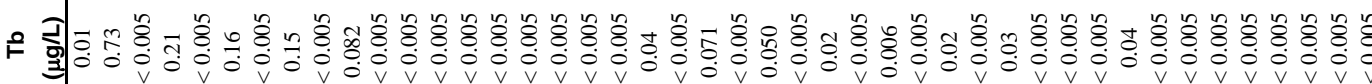

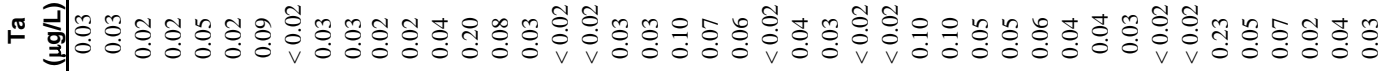

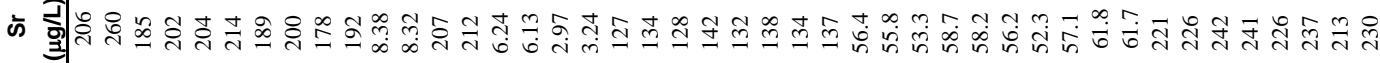

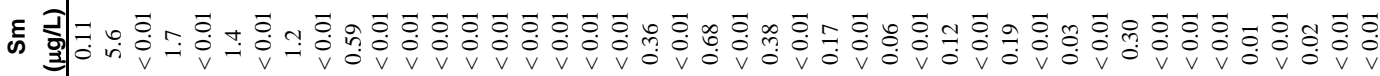

员㚜

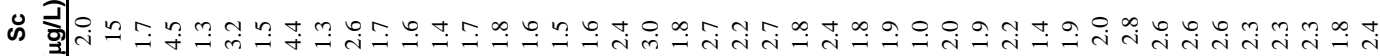

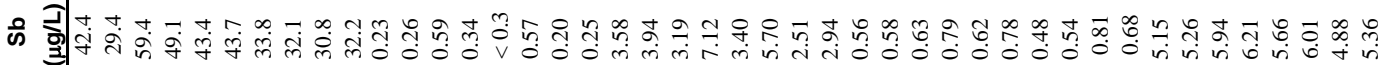

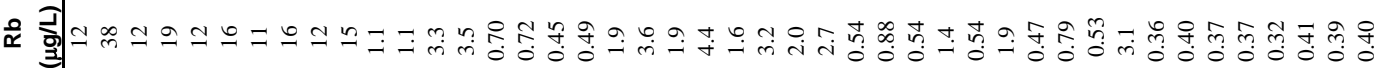

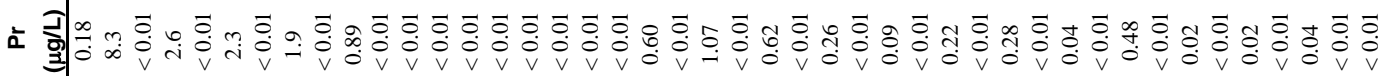

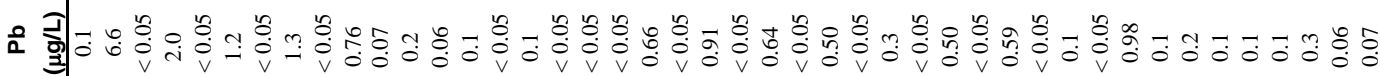

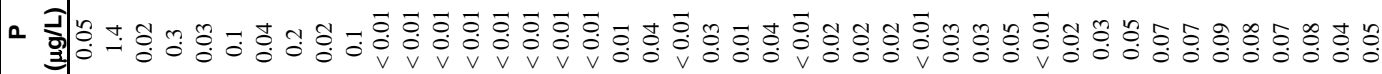

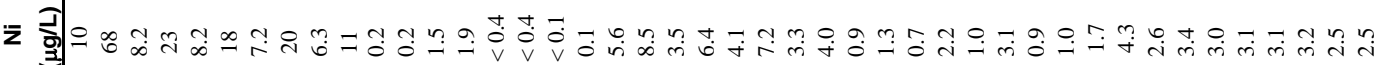

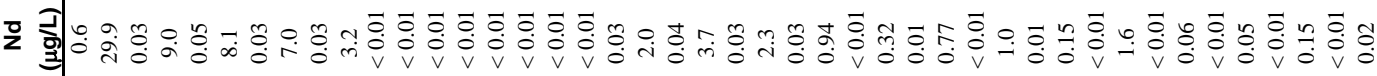

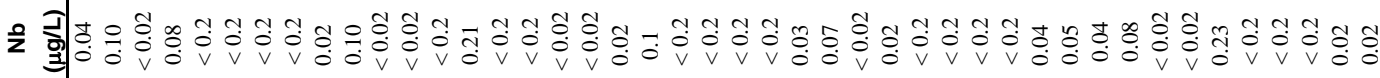

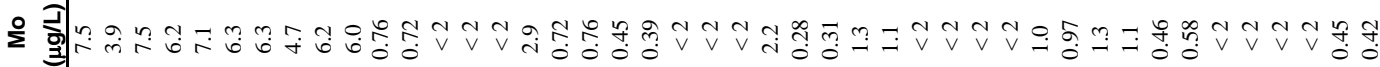

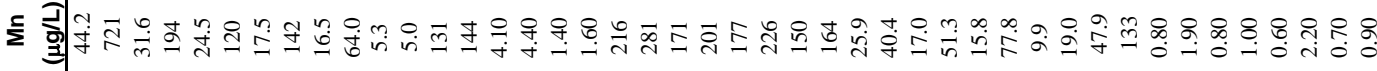

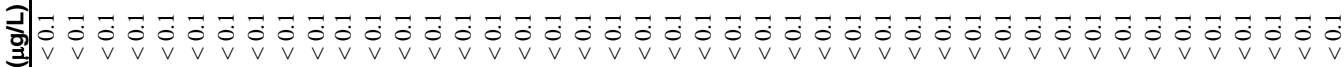

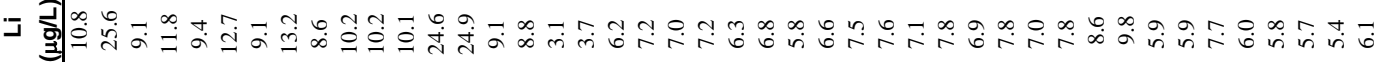

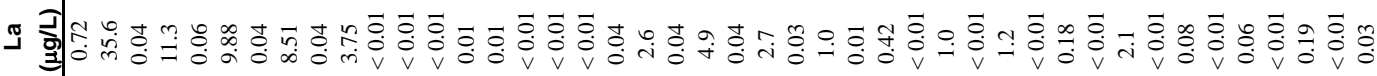

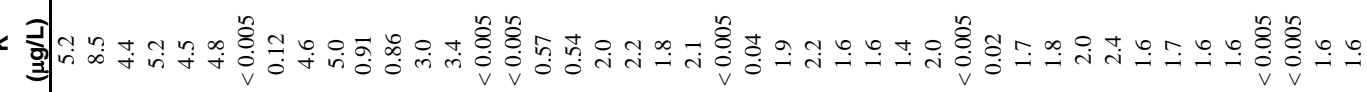

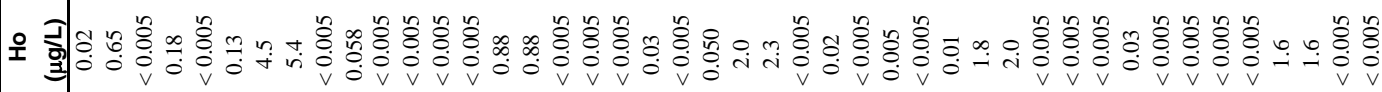

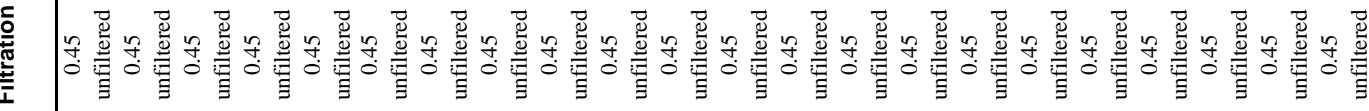

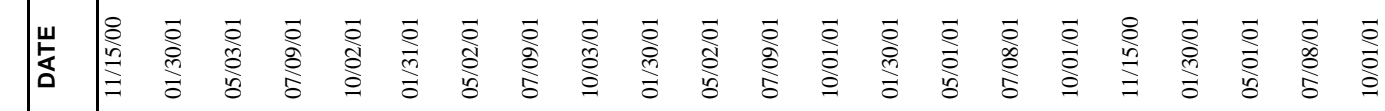




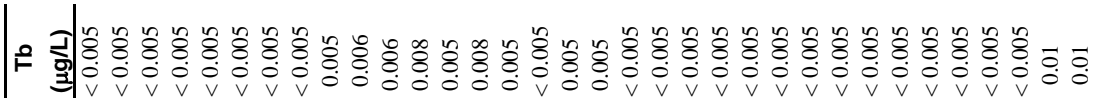

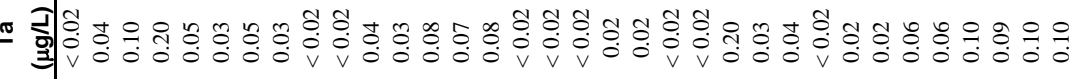

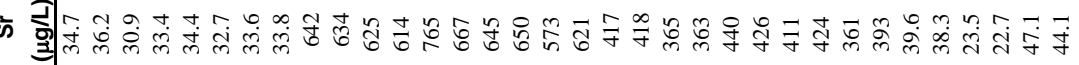

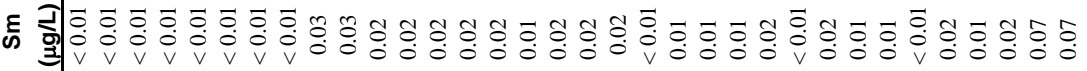

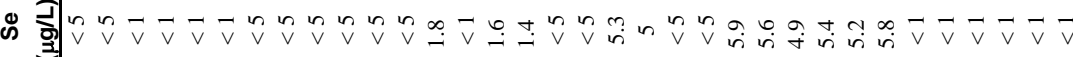

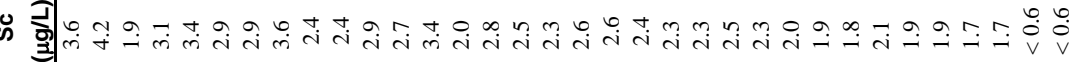
ज 局

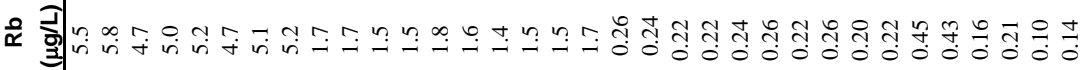

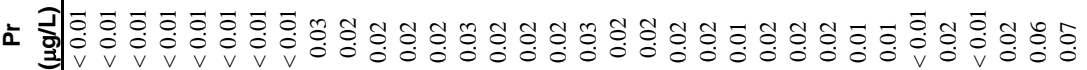

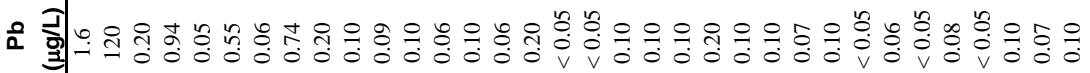

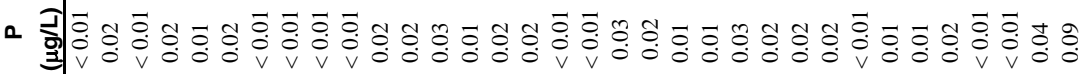

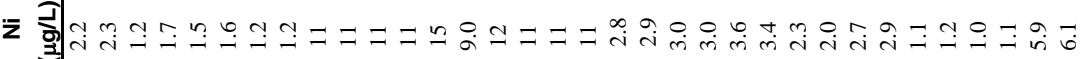

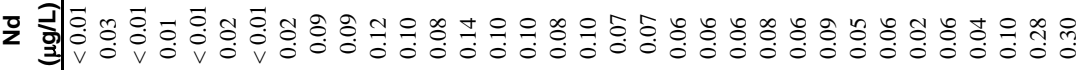

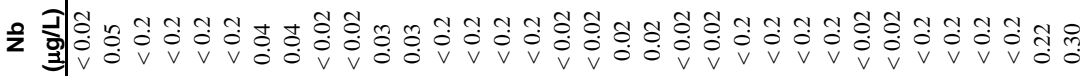

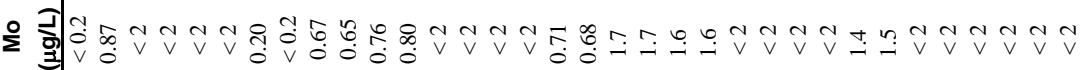

돈

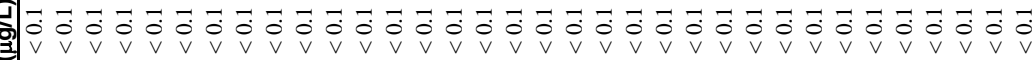
ت ح⿹

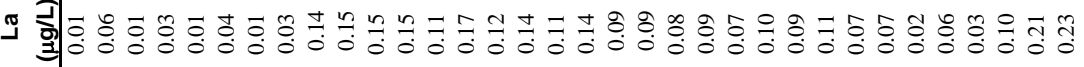
×

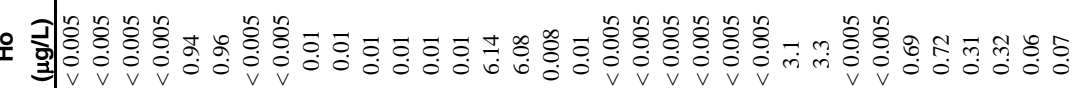

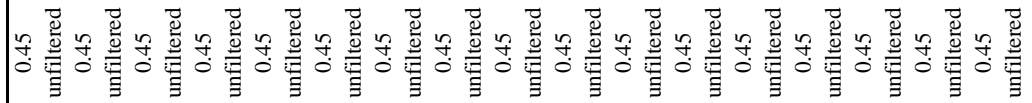

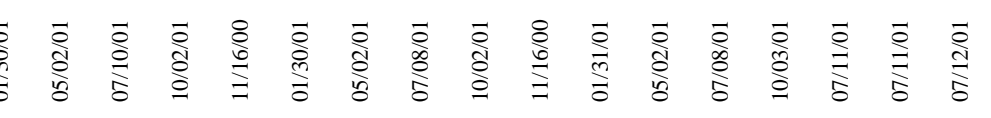




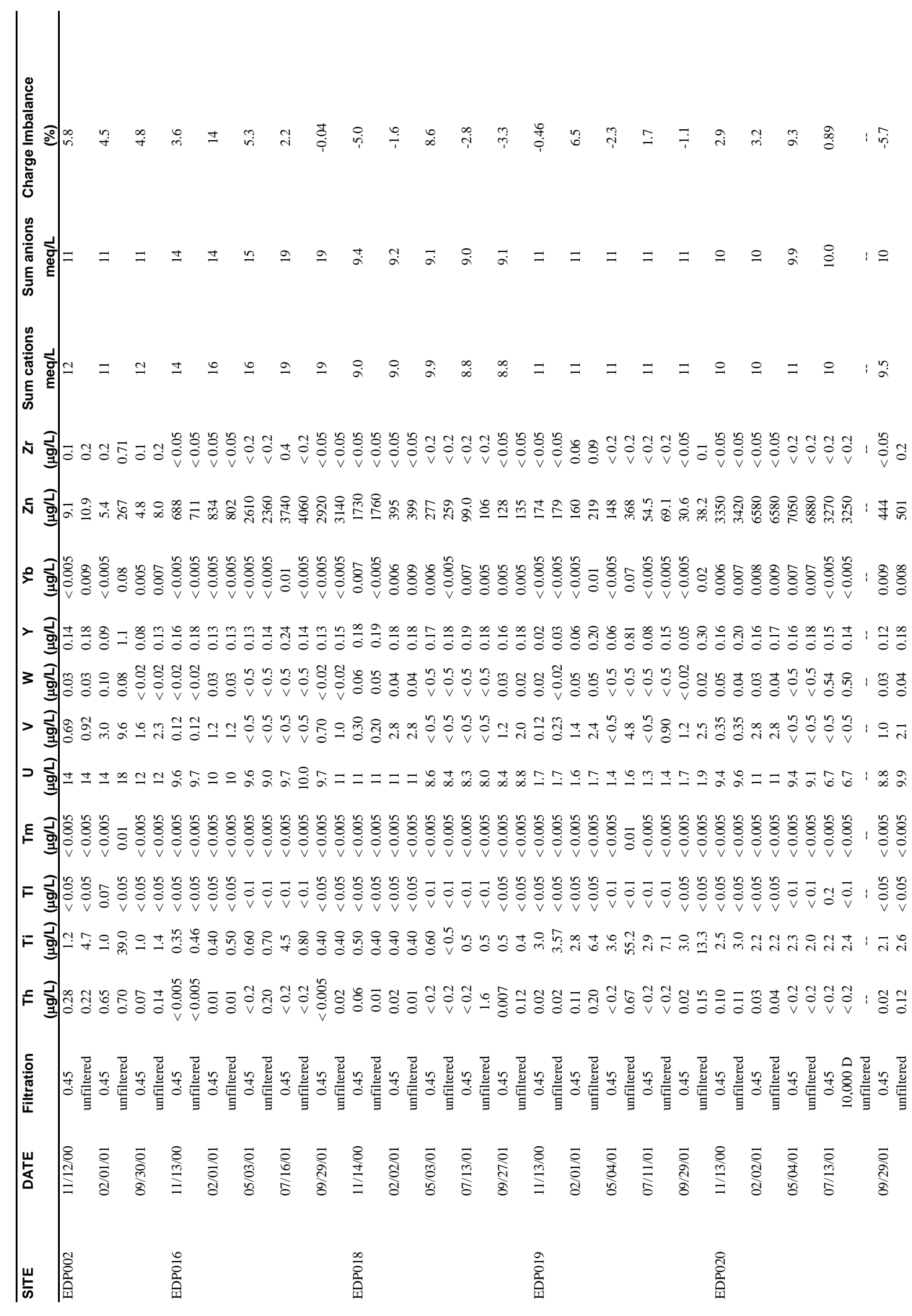


产

音

$\stackrel{n}{\circ}$

哥

N

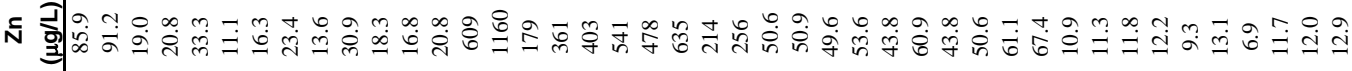

₹

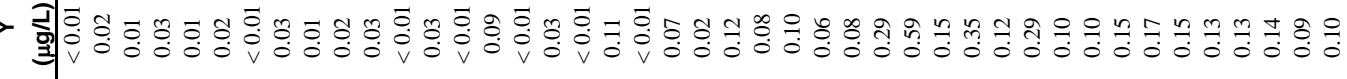

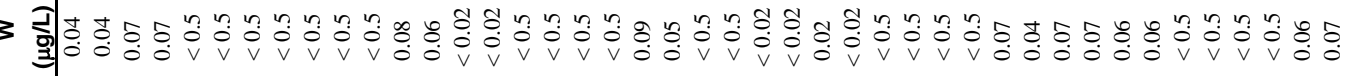

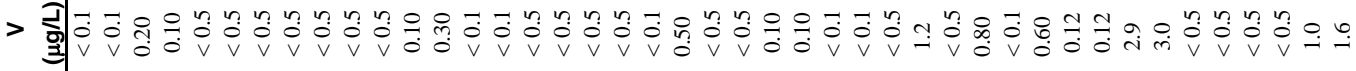

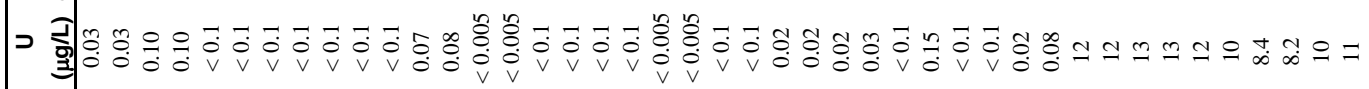

₹

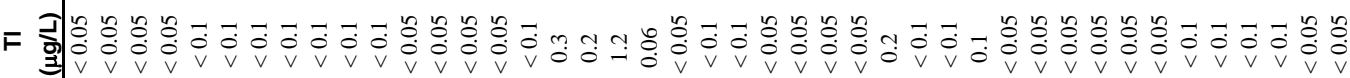

F

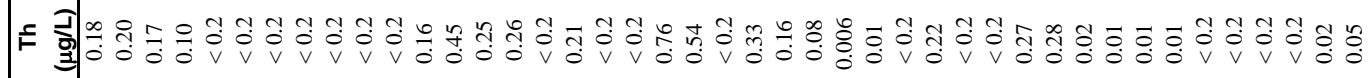

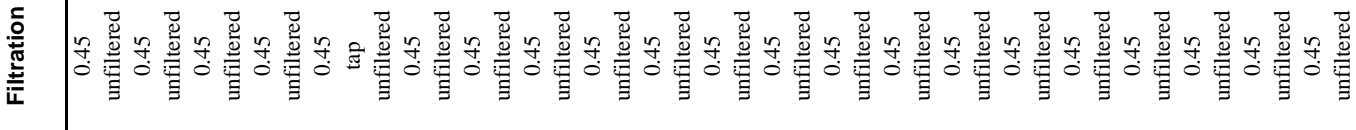

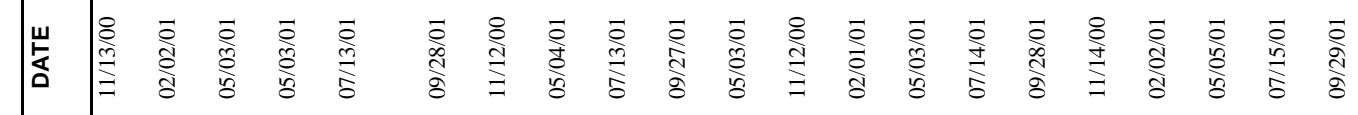

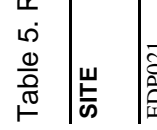

善

芯商

ֻั๊ 


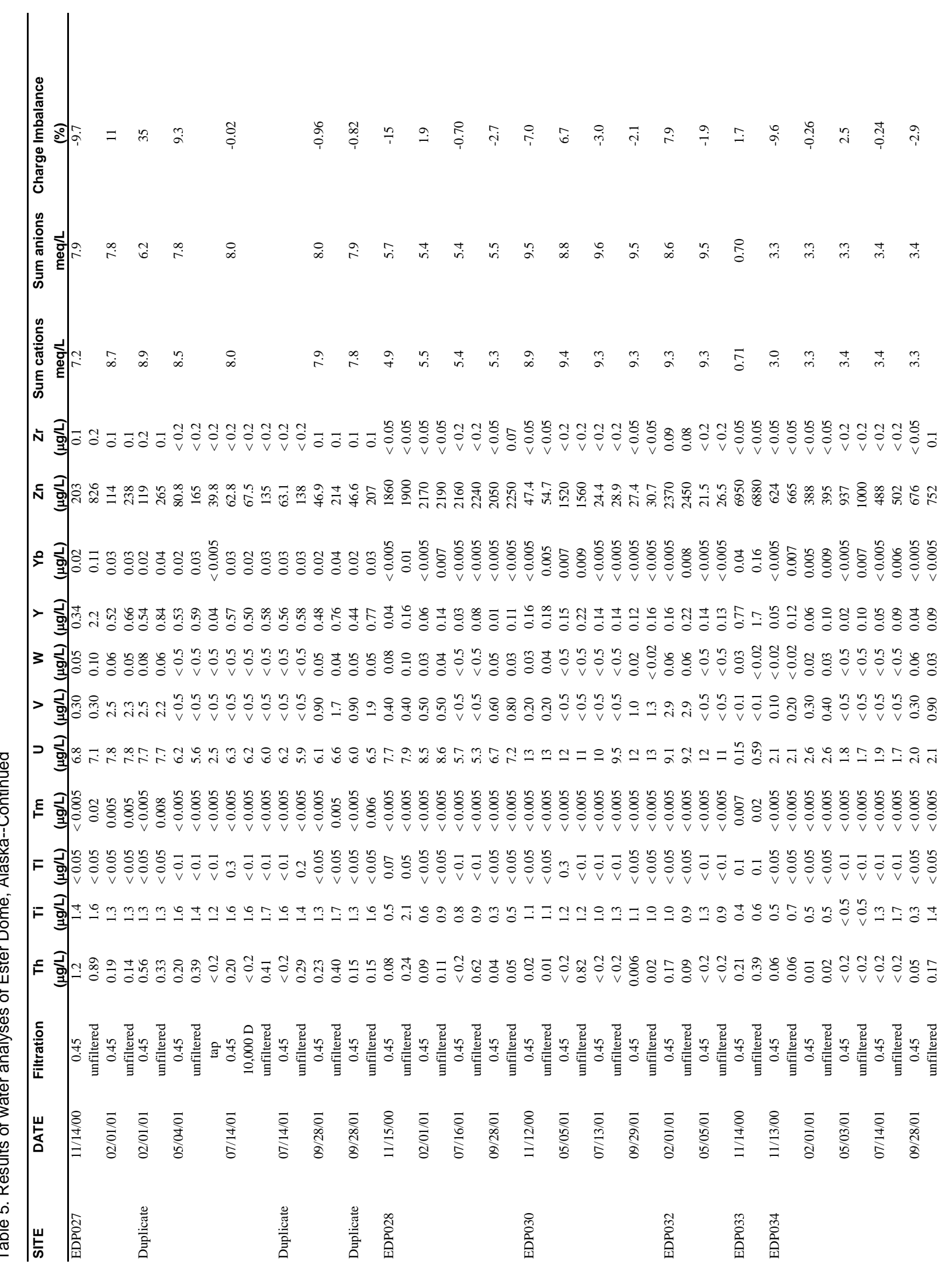




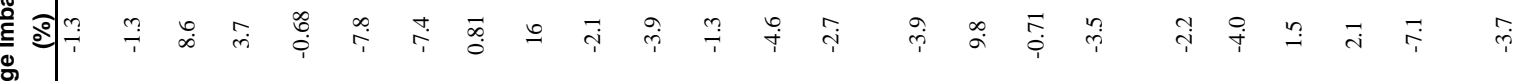

$\stackrel{0}{\circ}$

है

$\stackrel{2}{0}$

要

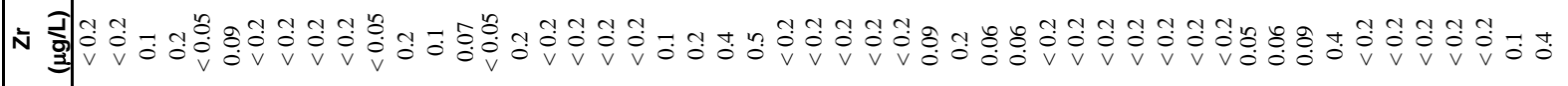

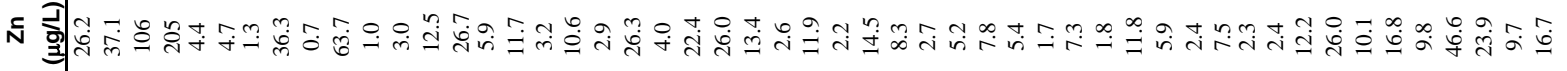

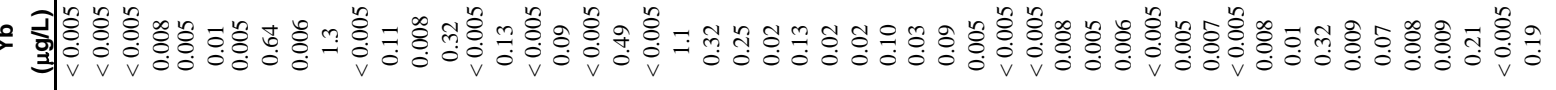

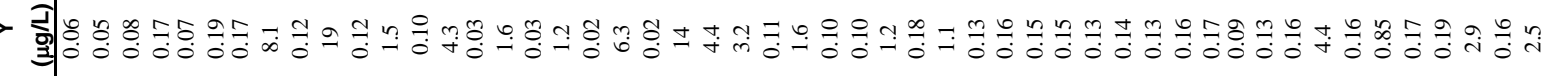

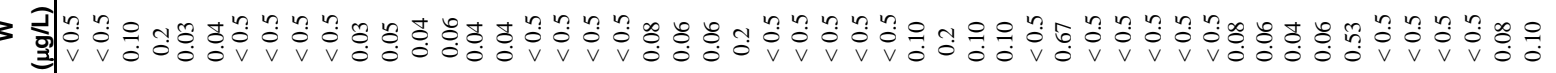

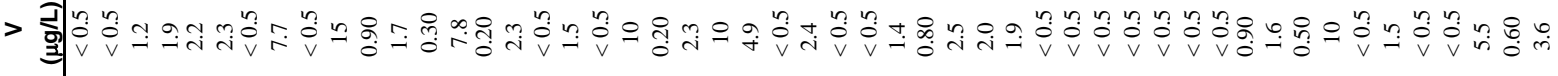

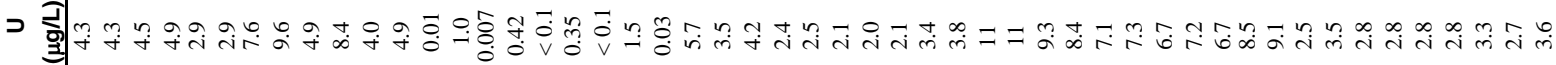

E

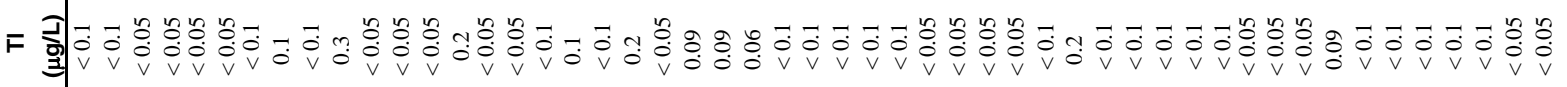

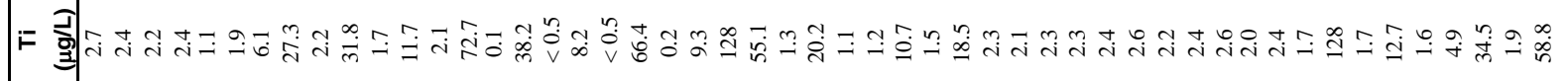

F

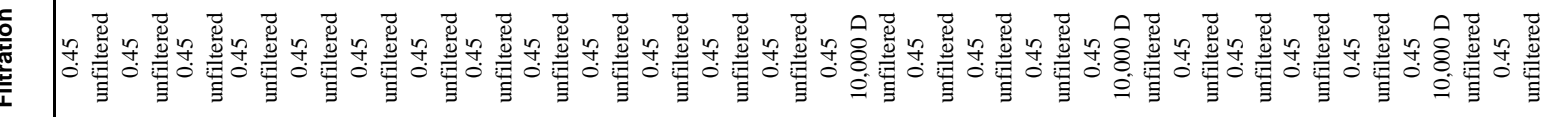

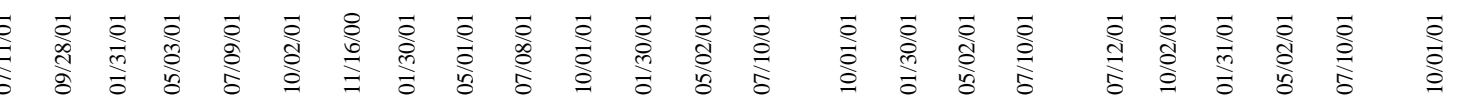

$\sum_{i=1}^{\infty} \quad \sum_{i}^{\mathbb{3}}$

总

$\underset{3}{\stackrel{\Xi}{3}}$

$\underset{\substack{3 \\ \Sigma}}{\stackrel{4}{3}}$ 


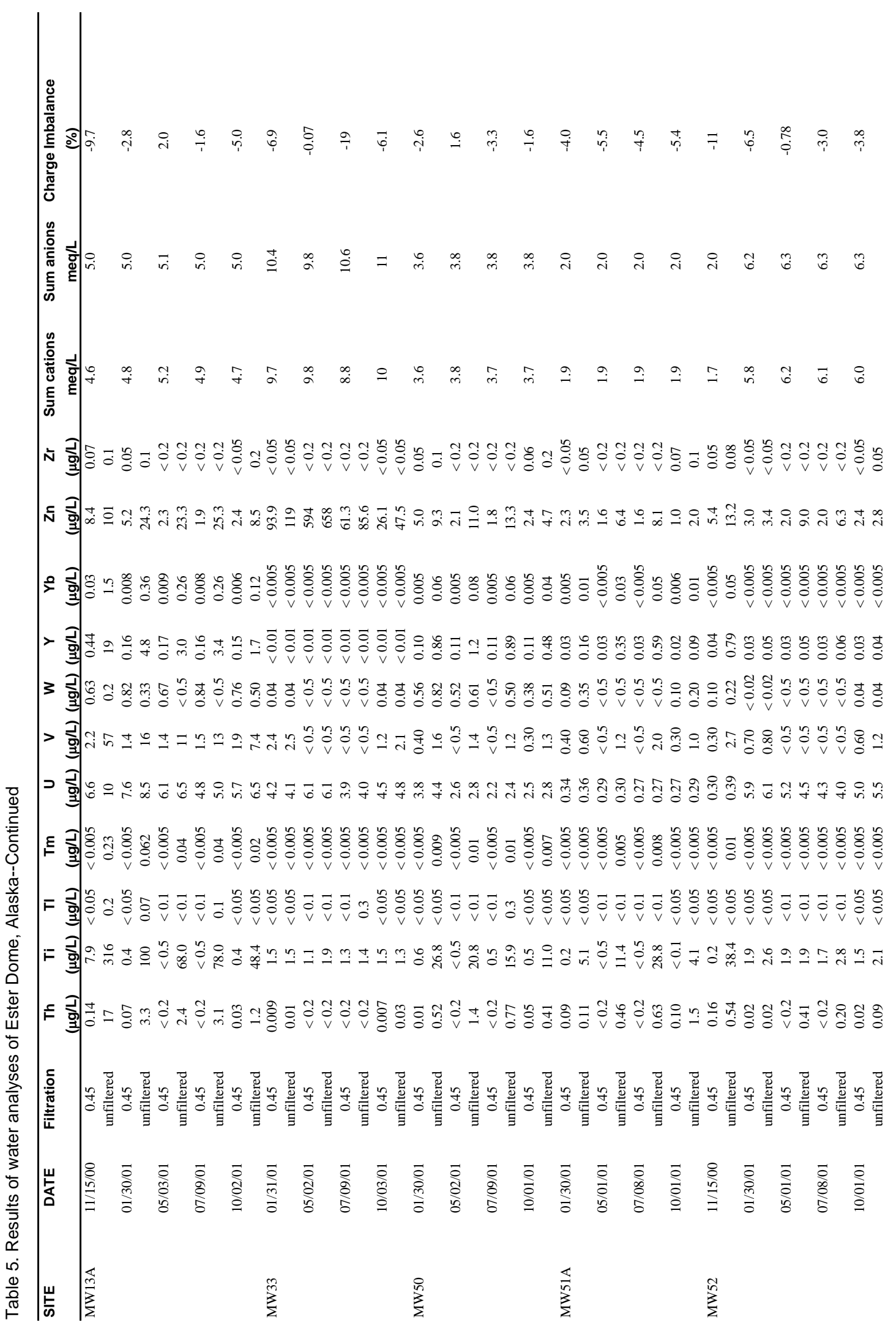




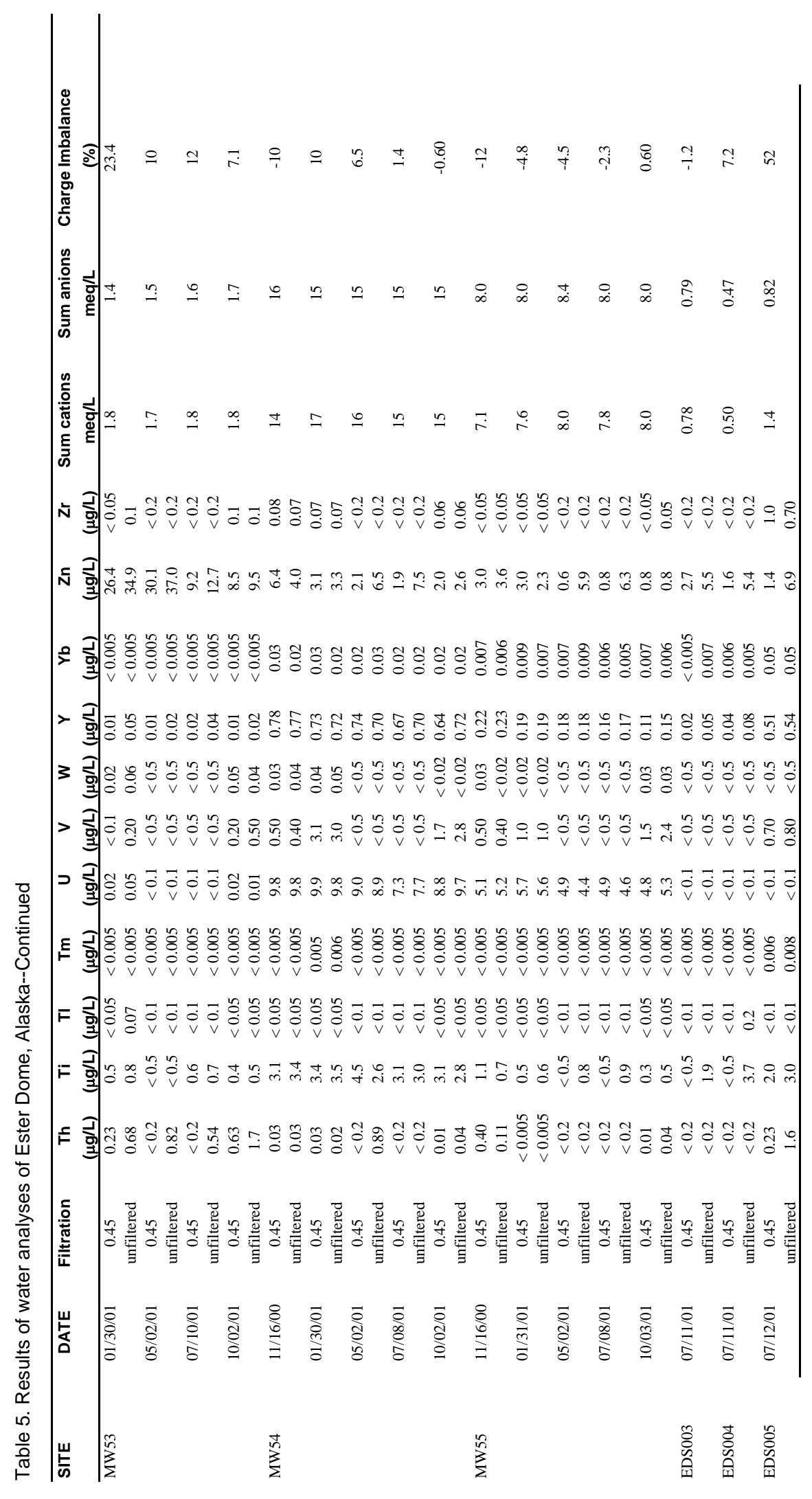


Table 6. Water-quality data for field blanks, Ester Dome, Alaska

[mg/L, milligram per liter; $\mu \mathrm{g} / \mathrm{L}$, microgram per liter; <, less than]

\begin{tabular}{|c|c|c|c|c|c|c|c|c|c|c|}
\hline DATE & TIME & $\begin{array}{l}\text { ALKALINITY } \\
\text { as mg/L } \mathrm{HCO}_{3}\end{array}$ & $\begin{array}{c}\mathrm{Br} \\
\mathrm{mg} / \mathrm{L}\end{array}$ & $\begin{array}{r}\mathrm{Ca} \\
\mathrm{mg} / \mathrm{L}\end{array}$ & $\begin{array}{c}\mathrm{Cl} \\
\mathrm{mg} / \mathrm{L}\end{array}$ & $\begin{array}{c}\mathrm{F} \\
\mathrm{mg} / \mathrm{L}\end{array}$ & $\begin{array}{l}\mathrm{Fe}(\mathrm{T}) \\
\mathrm{mg} / \mathrm{L}\end{array}$ & $\begin{array}{c}\mathrm{K} \\
\mathrm{mg} / \mathrm{L}\end{array}$ & $\begin{array}{r}\mathrm{Mg} \\
\mathrm{mg} / \mathrm{L}\end{array}$ & $\begin{array}{r}\mathrm{Na} \\
\mathrm{mg} / \mathrm{L}\end{array}$ \\
\hline $2 / 2 / 2001$ & 945 & $<1$ & $<0.1$ & $<0.1$ & $<0.4$ & $<0.1$ & $<0.002$ & $<0.1$ & $<0.1$ & $<0.1$ \\
\hline $5 / 3 / 2001$ & 1545 & 0.19 & $<0.1$ & 0.11 & $<0.4$ & $<0.2$ & $<0.002$ & $<0.1$ & $<0.1$ & $<0.1$ \\
\hline $7 / 13 / 2001$ & 1245 & $<1$ & $<0.1$ & $<0.1$ & $<0.4$ & $<0.2$ & $<0.002$ & $<0.1$ & $<0.1$ & $<0.1$ \\
\hline $9 / 28 / 2001$ & 1135 & $<1$ & $<0.2$ & $<0.1$ & 0.6 & $<0.1$ & $<0.002$ & $<0.1$ & $<0.1$ & $<0.1$ \\
\hline DATE & $\begin{array}{c}\mathrm{NO}_{3} \\
\mathrm{mg} / \mathrm{L} \\
\end{array}$ & $\begin{array}{c}\mathrm{SiO}_{2} \\
\mathrm{mg} / \mathrm{L} \\
\end{array}$ & $\begin{array}{c}\mathrm{SO}_{4} \\
\mathrm{mg} / \mathrm{L}\end{array}$ & $\begin{array}{c}\text { Ag } \\
\mu \mathrm{g} / \mathrm{L}\end{array}$ & $\begin{array}{c}\text { Al } \\
\mu \mathrm{g} / \mathrm{L}\end{array}$ & $\begin{array}{c}\text { As } \\
\mu \mathrm{g} / \mathrm{L}\end{array}$ & $\begin{array}{c}\mathrm{Ba} \\
\mu \mathrm{g} / \mathrm{L} \\
\end{array}$ & $\begin{array}{c}\mathrm{Be} \\
\mu \mathrm{g} / \mathrm{L} \\
\end{array}$ & $\begin{array}{c}\mathbf{B i} \\
\mu \mathrm{g} / \mathrm{L} \\
\end{array}$ & $\begin{array}{r}\text { Cd } \\
\mu \mathrm{g} / \mathrm{L} \\
\end{array}$ \\
\hline $2 / 2 / 2001$ & $<0.1$ & $<0.2$ & $<0.1$ & $<3$ & 0.82 & $<3$ & $<0.1$ & $<0.05$ & $<0.005$ & $<0.02$ \\
\hline 5/3/2001 & $<0.3$ & $<0.2$ & $<0.5$ & $<3$ & 3.5 & $<3$ & $<0.2$ & $<0.05$ & $<0.2$ & $<0.02$ \\
\hline $7 / 13 / 2001$ & $<0.3$ & $<0.2$ & $<0.5$ & $<3$ & $<2$ & $<3$ & $<0.2$ & $<0.05$ & $<0.2$ & $<0.02$ \\
\hline $9 / 28 / 2001$ & $<0.5$ & 6.1 & $<0.8$ & $<3$ & $<0.1$ & $<3$ & $<0.1$ & $<0.05$ & $<0.005$ & $<0.02$ \\
\hline
\end{tabular}

\begin{tabular}{|c|c|c|c|c|c|c|c|c|c|c|}
\hline DATE & $\begin{array}{c}\text { Ce } \\
\mu \mathrm{g} / \mathrm{L}\end{array}$ & $\begin{array}{c}\mathrm{Co} \\
\mu \mathrm{g} / \mathrm{L}\end{array}$ & $\begin{array}{c}\mathrm{Cr} \\
\mu \mathrm{g} / \mathrm{L}\end{array}$ & $\begin{array}{c}\text { Cs } \\
\mu \mathrm{g} / \mathrm{L}\end{array}$ & $\begin{array}{r}\mathrm{Cu} \\
\mu \mathrm{g} / \mathrm{L}\end{array}$ & $\begin{array}{c}\text { Dy } \\
\mu \mathrm{g} / \mathrm{L}\end{array}$ & $\begin{array}{c}\text { Er } \\
\mu \mathrm{g} / \mathrm{L}\end{array}$ & $\begin{array}{c}\text { Eu } \\
\mu \mathrm{g} / \mathrm{L}\end{array}$ & $\begin{array}{c}\text { Ga } \\
\mu \mathrm{g} / \mathrm{L}\end{array}$ & $\begin{array}{r}\text { Gd } \\
\mu \mathrm{g} / \mathrm{L}\end{array}$ \\
\hline $2 / 2 / 2001$ & $<0.01$ & $<0.02$ & $<1$ & 0.01 & $<0.5$ & $<0.005$ & $<0.005$ & $<0.005$ & $<0.02$ & $<0.005$ \\
\hline 5/3/2001 & $<0.01$ & $<0.02$ & $<1$ & 0.03 & $<0.5$ & $<0.005$ & $<0.005$ & $<0.005$ & $<0.05$ & $<0.005$ \\
\hline 7/13/2001 & $<0.01$ & $<0.02$ & $<1$ & $<0.02$ & $<0.5$ & $<0.005$ & $<0.005$ & $<0.005$ & $<0.05$ & $<0.005$ \\
\hline $9 / 28 / 2001$ & $<0.01$ & $<0.02$ & $<1$ & $<0.01$ & $<0.5$ & $<0.005$ & $<0.005$ & $<0.005$ & $<0.02$ & $<0.005$ \\
\hline
\end{tabular}

\begin{tabular}{|c|c|c|c|c|c|c|c|c|c|c|}
\hline DATE & $\begin{array}{c}\text { Ge } \\
\mu \mathrm{g} / \mathrm{L}\end{array}$ & $\begin{array}{r}\text { Ho } \\
\mu \mathrm{g} / \mathrm{L}\end{array}$ & $\begin{array}{c}\mathbf{K} \\
\mu \mathbf{g} / \mathbf{L}\end{array}$ & $\begin{array}{c}\text { La } \\
\mu \mathbf{g} / \mathbf{L} \\
\end{array}$ & $\begin{array}{c}\mathbf{L i} \\
\mu \mathrm{g} / \mathrm{L} \\
\end{array}$ & $\begin{array}{c}\text { Lu } \\
\mu \mathrm{g} / \mathrm{L}\end{array}$ & $\begin{array}{c}\text { Mn } \\
\mu \mathrm{g} / \mathrm{L}\end{array}$ & $\begin{array}{r}\mathrm{Mo} \\
\mu \mathrm{g} / \mathrm{L} \\
\end{array}$ & $\begin{array}{c}\mathrm{Nb} \\
\mu \mathrm{g} / \mathrm{L}\end{array}$ & $\begin{array}{c}\text { Nd } \\
\mu \mathrm{g} / \mathrm{L}\end{array}$ \\
\hline $2 / 2 / 2001$ & $<0.02$ & $<0.005$ & $<0.03$ & $<0.01$ & 0.2 & $<0.1$ & 0.02 & $<0.2$ & $<0.02$ & $<0.01$ \\
\hline 5/3/2001 & $<0.05$ & $<0.005$ & $<0.03$ & $<0.01$ & $<0.1$ & $<0.1$ & $<0.2$ & $<2$ & $<0.2$ & $<0.01$ \\
\hline 7/13/2001 & $<0.05$ & $<0.005$ & $<0.03$ & $<0.01$ & $<0.1$ & $<0.1$ & $<0.2$ & $<2$ & $<0.2$ & $<0.01$ \\
\hline $9 / 28 / 2001$ & $<0.02$ & $<0.005$ & $<0.03$ & $<0.01$ & $<0.1$ & $<0.1$ & $<0.01$ & $<0.2$ & $<0.02$ & $<0.01$ \\
\hline
\end{tabular}

\begin{tabular}{|c|c|c|c|c|c|c|c|c|c|c|}
\hline DATE & $\begin{array}{c}\mathbf{N i} \\
\mu \mathrm{g} / \mathrm{L}\end{array}$ & $\begin{array}{c}\mathbf{P} \\
\mu \mathrm{g} / \mathrm{L}\end{array}$ & $\begin{array}{c}\mathrm{Pb} \\
\mu \mathrm{g} / \mathrm{L}\end{array}$ & $\begin{array}{c}\mathrm{Pr} \\
\mu \mathrm{g} / \mathrm{L}\end{array}$ & $\begin{array}{c}\mathbf{R b} \\
\mu \mathrm{g} / \mathrm{L}\end{array}$ & $\begin{array}{c}\mathrm{Sb} \\
\mu \mathrm{g} / \mathrm{L}\end{array}$ & $\begin{array}{c}\mathrm{Sc} \\
\mu \mathrm{g} / \mathrm{L}\end{array}$ & $\begin{array}{c}\text { Se } \\
\mu \mathrm{g} / \mathrm{L}\end{array}$ & $\begin{array}{c}\mathrm{Sm} \\
\mu \mathrm{g} / \mathrm{L}\end{array}$ & $\begin{array}{c}\mathrm{Sr} \\
\mu \mathrm{g} / \mathrm{L}\end{array}$ \\
\hline $2 / 2 / 2001$ & $<0.1$ & $<0.01$ & $<0.05$ & $<0.01$ & $<0.01$ & $<0.1$ & $<0.1$ & $<5$ & $<0.01$ & $<0.5$ \\
\hline 5/3/2001 & $<0.4$ & 0.02 & $<0.05$ & $<0.01$ & $<0.01$ & $<0.3$ & $<0.6$ & $<1$ & $<0.01$ & $<0.5$ \\
\hline $7 / 13 / 2001$ & $<0.4$ & $<0.01$ & $<0.05$ & $<0.01$ & $<0.01$ & $<0.3$ & $<0.6$ & $<1$ & $<0.01$ & $<0.5$ \\
\hline $9 / 28 / 2001$ & $<0.1$ & $<0.01$ & $<0.05$ & $<0.01$ & $<0.01$ & $<0.1$ & $<0.1$ & $<5$ & $<0.01$ & $<0.5$ \\
\hline
\end{tabular}

\begin{tabular}{ccccccccccc}
\hline DATE & $\mathbf{T a}$ & $\mathbf{T b}$ & $\mathbf{T h}$ & $\mathbf{T i}$ & $\mathbf{T l}$ & $\mathbf{T m}$ & $\mathbf{U}$ & $\mathbf{V}$ & $\mathbf{W}$ & $\mathbf{Y}$ \\
& $\mu \mathbf{g} / \mathbf{L}$ & $\mu \mathbf{g} / \mathbf{L}$ & $\mu \mathbf{g} / \mathbf{L}$ & $\mu \mathbf{g} / \mathbf{L}$ & $\mu \mathbf{g} / \mathbf{L}$ & $\mu \mathbf{g} / \mathbf{L}$ & $\mu \mathbf{g} / \mathbf{L}$ & $\mu \mathbf{g} / \mathbf{L}$ & $\mu \mathbf{g} / \mathbf{L}$ & $\mu \mathbf{g} / \mathbf{L}$ \\
\hline $2 / 2 / 2001$ & 0.02 & $<0.005$ & $<0.005$ & $<0.1$ & $<0.05$ & $<0.005$ & $<0.005$ & $<0.1$ & 0.03 & $<0.01$ \\
$5 / 3 / 2001$ & 0.03 & $<0.005$ & $<0.2$ & $<0.5$ & $<0.1$ & $<0.005$ & $<0.1$ & $<0.5$ & $<0.5$ & $<0.01$ \\
$7 / 13 / 2001$ & 0.05 & $<0.005$ & $<0.2$ & $<0.5$ & $<0.1$ & $<0.005$ & $<0.1$ & $<0.5$ & $<0.5$ & $<0.01$ \\
$9 / 28 / 2001$ & $<0.02$ & $<0.005$ & $<0.005$ & $<0.1$ & $<0.05$ & $<0.005$ & $<0.005$ & $<0.1$ & $<0.02$ & $<0.01$ \\
\hline
\end{tabular}

\begin{tabular}{cccc}
\hline DATE & $\begin{array}{c}\text { Yb } \\
\mu \mathbf{g} / \mathbf{L}\end{array}$ & $\begin{array}{c}\mathbf{Z n} \\
\boldsymbol{\mu g} / \mathbf{L}\end{array}$ & $\begin{array}{c}\mathbf{Z r} \\
\boldsymbol{\mu g} / \mathbf{L}\end{array}$ \\
\hline $2 / 2 / 2001$ & $<0.005$ & 0.7 & $<0.05$ \\
$5 / 3 / 2001$ & $<0.005$ & $<0.5$ & $<0.2$ \\
$7 / 13 / 2001$ & $<0.005$ & 1.8 & $<0.2$ \\
$9 / 28 / 2001$ & $<0.005$ & $<0.5$ & $<0.05$ \\
\hline
\end{tabular}




\section{REFERENCES CITED}

Aiken, G.R., 1992, Chloride interference in the analysis of dissolved organic carbon by the wet oxidation method: Environmental Science and Technology, v. 26, p. 2435-2439.

Alpers, C.N., Taylor, H.E., Roth, D.A., Cain, D.J., Ball, J.W., Unruh, D.M., and Dileanis, P.D., 2000, Study Design: Field and Laboratory Methods, in Alpers, C.N., Taylor, H.E., and Domagalski, J.L., eds., Metals transport in the Sacramento River, California, 1996-1997: U.S. Geological Survey Water-Resources Investigations Report 99-4286, p. 19-38.

Ball, J.W. and Nordstrom, D.K., 1991, User's manual for WATEQ4F, with revised thermodynamic data base and test cases for calculating speciation of major, trace, and redox elements in natural waters: U.S. Geological Survey Open-File Report 91-183, 189 p.

Barringer, J.L. and Johnsson, P.A., 1989, Theoretical considerations and a simple method for measuring alkalinity and acidity in low-pH waters by gran titration: U.S. Geological Survey, Water-Resources Investigations Report 89-4029. 35 p.

Briggs, P.H., 2002, The determination of twenty-seven elements in aqueous samples by inductively coupled plasma- atomic emission spectrometry: in Taggart, J.E., ed., Analytical methods for chemical analysis of geologic and other materials, U.S. Geological Survey: U.S. Geological Survey Open-File Report 02-223, ch. F, 11 p.

Brinton, T.I., Antweiler, R.C., and Taylor, H.E., 1995, Method for the determination of dissolved chloride, nitrate and sulfate in natural water using ion chromatography: U.S. Geological Survey Open-File Report 95-426, 16 p.

Epstein, S., and Mayeda, T., 1953, Variations of O18 contents of waters from natural sources: Geochimica et Cosmochimica Acta, 4, p. 213-224.

Edwards, T.K. and Glysson, D.G., 1988, Field methods for measurement of fluvial sediment: U.S. Geological Survey Open-File Report 86-531, 118 p.

Farmer, G.L., Goldfarb, R.J., Lilly, M.R., Bolton, B., Meier, A.L, and Sanzolone, R.F., 1998, The chemical characteristics of ground water near Fairbanks, Alaska: in geological Studies in Alaska by the U.S. Geological Survey: Professional Paper 1615, p. 167-178.

Foster, H.L., Keith, T.E.C., and Menzie, W.D., 1994, Geology of the Yukon-Tanana area of east-central Alaska, in Plafker, G. and H.C. Berg, H.C. eds., The Geology of Alaska: Geological Society of America, Geology of North America, v. G-1, p. 205-240.

Giesemann, A., Jäger, H.J., Norman, A.L., Krouse, H.R., and Brand, W.A., 1994, On-line sulfur-isotope determination using an elemental analyzer coupled to a mass spectrometer: Analytical Chemistry, v. 66, p. 2816-2819.

Harrington, J.M., Middaugh, J.P., Morse, D.L., and Housworth, J., 1978, A survey of population exposed to high concentrations of arsenic in well water in Fairbanks, Alaska: American Journal of Epidemiology, v. 108, p. 377-385.

Hawkins, D.B., Forbes, R.B., Hok, C.I., and Dinkel, D., 1982, Arsenic in the water, soil, bedrock and plants of the Ester Dome area of Alaska: IWR-103, 82 p.

Johnson, P.R., Wilcox, D.E., Morgan, W.D., Merto, J., and McFadden, R., 1978, Arsenic, nitrate, iron, and hardness in ground water, Fairbanks, area, Alaska: U.S. Geological Survey Open-File Report 781034, 1 sheet.

Kane, D. L. and Stein, J., 1983. Water Movement into Seasonally Frozen Soils: Water Resources Research, v. 19, p. 1547-1557.

Kuehner, E.C., Alvarez, R., Paulsen, P.J., and Murphy, T.J., 1972, Production and analysis of special highpurity acids purified by sub-boiling distillation: Analytical Chemistry, v. 44, p. 2050-2056.

Lamothe, P.J., Meier, A.L., and Wilson, S.A., 2002, The determination of forty four elements in aqueous samples by inductively coupled plasma- mass spectrometry: in Taggart, J.E., ed., Analytical methods for chemical analysis of geologic and other materials, U.S. Geological Survey: U.S. Geological Survey Open-File Report 02-223, ch. H, 13 p.

LeLacheur, E.A., 1991, Brittle-Fault Hosted Gold Mineralization in the Fairbanks District, Alaska: Fairbanks, Alaska, University of Alaska, M.S. Thesis, 154 p.

McCoy, D., Newberry, R.J., Layer, P., Dimarchi, J.J., Bakke, A., Masterman, J.S., and Minehane, D.L., 1997, Plutonic-related gold deposits of interior Alaska, in Goldfarb, R.J. and Miller, L.D. eds., Mineral Deposists of Alaska: Economic Geology Monograph 9, p. 191-241. 
McCrum, M.A., 1985, A Chemical Mass Balance of the Ester Creek and Happy Creek Watersheds on Ester Dome, Alaska: Fairbanks, Alaska, University of Alaska, M.S. thesis, 141 p.

Meier, A.L., Grimes, D.J., and Ficklin, W.H., 1994, Inductively coupled plasma mass spectrometry-A powerful analytical tool for mineral resource and environmental studies [abs], in Carter, L.M.H., Toth, M.I., and Day, W.C., eds., USGS Research on Mineral Resources—1994, Part A-Program and Abstracts, Ninth V.E. McKelvey Forum on Mineral and Energy Resources: U.S. Geological Survey Circular 1103-A, p. 67-68.

Metz, P.A., 1991, Metallogeny of the Fairbanks Mining District, Alaska and Adjacent Areas: Mineral Industry Research Laboratory, University of Alaska, Fairbanks MIRL Report No. 90, 370 p.

Mueller, S.H., Verplanck, P.L., and Goldfarb, R.J., 2001, Ground-water studies in Fairbanks, Alaska-A better understanding of some of the United States' highest natural arsenic concentrations: U.S. Geological Survey, Fact Sheet 111-01.

Mueller, S.H., 2002, A geochemical characterization of groundwater near Fairbanks, Alaska, with emphasis on arsenic hydrogeochemistry, Boulder, Colorado, University of Colorado, MSc. thesis, 109 p.

National Weather Service, 2002, Climate data from the Fairbanks International Airport.

Newberry, R.J. and Bundtzen, T.K., 1996, Preliminary Geologic Map of the Fairbanks Mining District, Alaska: Alaska Division of Geological and Geophysical Surveys, Public Data File 96-12, 14 p., 2 sheets.

Pewe, T.L., 1958, Geology of the Fairbanks (D-2) Quadrangle, Alaska. Department of the Interior, U.S. Geological Survey.

Preece, S.J., Westgate J.A., Stemper, B.A., and Pewe, T.L., 1999, Teprochronology of late Cenozoic loess at Fairbanks, central Alaska: Geological Society of America Bulletin, 1999; v. 111, no. 1, p. 71-90.

Robinson, M.S., 1982, Bedrock geology of the Fairbanks Mining District, southeast sector: Alaska Division of Geological \& Geophysical Surveys, Alaska Open File Report 146. 1 plate.

Stookey, L. L., 1970, FerroZine - a new spectrophotometric reagent for iron: Analytical Chemistry, v. 42, p. $779-781$.

To, T.B., Nordstrom, D. K., Cunningham, K.M., Ball, J.W., and McCleskey, R.B., 1999, New method for direct determination of dissolved Fe(III) concentrations in acid mine waters: Environmental Science and Technology, v. 33, p. 807-813.

Verplanck, P.L., Mueller, S.H., Nordstrom, D.K., Goldfarb, R.J., Sanzolone, R.F., Youcha, E.K., and Roller, M., 2001, Arsenic variability in ground water, Ester Dome, Alaska. [abs.]: Geological Society of America Abstracts with Programs v. 33, no. 6, p. 54.

Youcha, E.K., 2003, A Geohydrologic analysis of an upland-bedrock aquifer system: Applications to interior Alaska, Fairbanks, Alaska, University of Alaska, MSc. Thesis, 140 p. 